\title{
The East Asian Financial Crisis: Diagnosis, Remedies, Prospects
}

“'History," Jawaharlal Nehru famously observed, “is almost always written by the victors." 'Financial history, it seems, is written by the creditors. When a financial crisis arises, it is the debtors who are asked to take the blame. This is odd, since a loan agreement invariably has two parties. The failure of a loan usually represents miscalculations on both sides of the transaction or distortions in the lending process itself.

The East Asian financial crisis has so far been true to form. As soon as the crisis hit in mid-1997, the International Monetary Fund (IMF), which led the official international response, assigned primary responsibility to the shortcomings of East Asian capitalism, in particular, the East Asian financial markets. The IMF's principal strategy for the three countries hardest hit-Indonesia, Korea, and Thailand-was to overhaul their financial systems. The basic diagnosis was that East Asia had exposed itself to financial chaos because its financial systems were riddled by insider dealing, corruption, and weak corporate governance,

We are grateful for excellent research assistance from Mumtaz Hussain, Dilip Parajuli, Amar Hamoudi, and Gopal Garuda, and for valuable input from Frank Flatters. We also thank very much our discussants, Richard Cooper and Barry Bosworth, for their comments and suggestions. This work was partially sponsored by the Office of Emerging Markets, Economic Growth Center, Bureau for Global Programs, Field Support and Research, U.S. Agency for International Development, under the Consulting Assistance on Economic Reform (CAER) II project (contract PCE-0405-C-00-5015-00). The views and interpretations in this paper are those of the authors and should not be attributed to USAID.

1. Nehru (1946, p. 287). 
which, in turn, had led to inefficient investment spending and had weakened the stability of the banking system.

There is some truth in such claims. And yet the hypothesis that East Asia's financial shortcomings alone caused the crisis and fully explain its depth fits uncomfortably with several important facts. First, the East Asian economies had been highly successful for a generation, belying the notion of fatally dysfunctional economies. Second, the 1997 crisis was largely unanticipated, a point which also seems to be at odds with allegations of the long-standing ills of these economies. A few voices, notably Yung Chul Park in Brookings Papers on Economic Activity, had warned that East Asia could be subject to the same kind of crisis that had hit Mexico in 1994-95, but they were rare and generally unheeded. ${ }^{2}$ And even though many observers saw some danger signs in late 1996-for example, in the overvaluation of the Thai baht-they did not anticipate the kind of financial meltdown that has in fact occurred. Third, and related to the first two points, foreign investors flooded the region with funds until the onset of the crisis.

Why, then, have the East Asian economies temporarily collapsed? The magnitude and suddenness of the financial reversal are made clear in table 1, which records net capital flows to the five East Asian crisis economies: Indonesia, Korea, Malaysia, the Philippines, and Thailand. Private net inflows to these five countries soared, rising from $\$ 40.5$ billion in 1994 to $\$ 93.0$ billion in 1996 . But in 1997 the long period of inflow abruptly reversed, with a net outflow of around $\$ 12.1$ billion. The remarkable and unexpected swing of capital flows of $\$ 105$ billion (from $\$ 93$ billion inflow to $\$ 12$ billion outflow) represents around 11 percent of the precrisis dollar GDP of these five countries.

This paper begins by examining the broad characteristics of some recent financial crises: Mexico in 1994-95, Argentina in 1995, and in East Asia in 1997, Indonesia, Korea, Malaysia, the Philippines, and Thailand. Each of these episodes displays elements of a self-fulfilling crisis, in which capital withdrawals by creditors cascade into a financial panic and result in an unnecessarily deep contraction. As we stress throughout, the panic may be "rational" on the part of individual creditors, each of whom is trying to flee ahead of the others, even though the collective result is disastrous and the panic is unnecessary, 
Table 1. External Financing of Five Asian Countries, 1994-98

Billions of dollars

\begin{tabular}{|c|c|c|c|c|c|}
\hline Item & 1994 & 1995 & 1996 & $1997^{\mathrm{b}}$ & $1998^{\mathrm{c}}$ \\
\hline Current account balance & -24.6 & -41.3 & -54.9 & -26.0 & 17.6 \\
\hline External financing (net) & 47.4 & 80.9 & 92.8 & 15.2 & 15.2 \\
\hline Private inflows (net) & 40.5 & 77.4 & 93.0 & -12.1 & -9.4 \\
\hline Equity investment & 12.2 & 15.5 & 19.1 & -4.5 & 7.9 \\
\hline Direct & 4.7 & 4.9 & 7.0 & 7.2 & 9.8 \\
\hline Portfolio & 7.6 & 10.6 & 12.1 & -11.6 & -1.9 \\
\hline Private creditors & 28.2 & 61.8 & 74.0 & -7.6 & -17.3 \\
\hline Commercial banks & 24.0 & 49.5 & 55.5 & -21.3 & -14.1 \\
\hline Nonbank & 4.2 & 12.4 & 18.4 & 13.7 & -3.2 \\
\hline Official inflows (net) & 7.0 & 3.6 & -0.2 & 27.2 & 24.6 \\
\hline International institutions & -0.4 & -0.6 & -1.0 & 23.0 & 18.5 \\
\hline Bilateral creditors & 7.4 & 4.2 & 0.7 & 4.3 & 6.1 \\
\hline Resident lending and other (net) ${ }^{\mathrm{d}}$ & -17.5 & -25.9 & -19.6 & -11.9 & -5.7 \\
\hline Reserves change, excluding golde & -5.4 & -13.7 & -18.3 & 22.7 & -27.1 \\
\hline
\end{tabular}

Source: Institute of International Finance, "Capital Flows to Emerging Market Economies," January 29, 1998

a. Table entries are sums over data for Korea, Indonesia, Malaysia, Thailand, and the Philippines.

b. Estimate.

c. Forecast.

d. Includes resident net lending, monetary gold, and errors and omissions.

e. A negative value indicates an increase.

in the sense that the fundamentals could have supported a much more favorable outcome. In short, international financial markets are intrinsically highly unstable; or to put it another way, the East Asian crisis is as much a crisis of Western capitalism as of Asian capitalism.

The paper then considers other factors that have contributed to the crisis. East Asia was hit by several international macroeconomic shocks during 1994-96, including a dramatic surge by competitor economies (China and Mexico, in particular) and the abrupt reversal of the longterm trend of the yen's appreciation relative to the dollar. While these shocks appear to have had only a modest direct impact on Asia's economic performance, they interacted with growing weaknesses in East Asian financial systems to provoke the crisis. Each of the five crisis economies had initiated, but had not completed, financial sector liberalization and reform. The partial reforms had led to increasingly fragile financial systems, characterized by growing short-term foreign debt, rapidly expanding bank credit, and inadequate regulation and supervision of financial institutions. These weaknesses, in turn, left the Asian economies vulnerable to a rapid reversal of capital flows.

Once the capital withdrawals were underway, mistakes by both Asian 
governments and the IMF contributed to the panic and unnecessarily deepened the crisis. Thailand and Korea, in particular, failed to take appropriate actions in late 1996 and early 1997 that could have headed off the crisis. At a later stage, the IMF's exclusive focus on "fixing", Asia, without proper regard to the root problems of international financial market instability, imposed excessive costs on the East Asian economies.

Finally, we consider strategies to avoid future financial crises in emerging markets. We examine several options that would allow emerging markets to slow, but not eliminate, short-term capital inflows and reduce the vulnerability of financial institutions to rapid reversals of capital. We also discuss the possibility of a new international strategy for dealing with incipient financial crises.

\section{Emerging Market Crises}

In an emerging market financial crisis, an economy that has been the recipient of large-scale capital inflows stops receiving such inflows and instead faces sudden demands for the repayment of outstanding loans. This abrupt reversal of flows leads to financial embarrassment, as loans fall into default or at least are pushed to the brink of default. The outcome of the reversal of capital flows may be a period of outright default, a rescheduling of debt payments, or rescue by a lender who provides a new loan to finance the repayments of past loans that are falling due.

In the twentieth century there have been several dramatic international financial crises involving developing countries. In fall 1929, the flow of bond financing from the United States to Latin America suddenly dried up, leading to widespread defaults by Latin American sovereign borrowers that took nearly a generation to resolve. In August 1982, Mexico was pushed to the brink of default when it was unable to roll over short-term debts that were falling due. The Mexican crisis was soon followed by a generalized withdrawal of credits from developing countries, which, in turn, led to debt reschedulings, defaults, and renegotiations in a dozen debtor countries. Chile, Uruguay, and Argentina also experienced financial crises in the early 1980s, following 
financial deregulation in the late 1970 s. $^{3}$ More recently, there have been several dramatic reversals in large-scale lending to emerging markets: Mexico, Turkey, and Venezuela in 1994; Argentina in early 1995; and the East Asian countries in 1997. In five of these recent cases-Mexico, Argentina, Indonesia, Korea, and Thailand-extraordinary international loans were arranged to forestall defaults on debt servicing.

These episodes shared certain characteristics: they were marked by sudden shifts in financial flows; they were to some extent unanticipated; and they provoked deep economic contractions within the debtor countries, as well as losses to some of the foreign investors, especially equity investors. Most analysts have tried to explain these crises in terms of two categories of "fundamental" factors: (1) abrupt changes in international market conditions that affect the ability of debtors to repay outstanding loans, such as shifts in interest rates, commodity prices, or trade conditions; and (2) abrupt shifts in the debtor country that cause creditors to reassess that country's ability or willingness to service the foreign debt, including changes in political leadership or economic policy, or in the burden of the debt (for example, because of new information about the overall size of external debt obligations).

In the 1929 crisis, the main factor behind the cessation of bond finance is alleged to have been the boom conditions in U.S. financial markets, which tightened the terms for new international bond issuances. In addition, falling international commodity prices called into question the ability of commodity-exporting countries in Latin America to service their debts. Soon after the lending stopped, global economic conditions grew markedly worse, with the onset of the Great Depression and the rise of protectionism in countries throughout the world. In the 1982 debt crisis in Mexico, the most important shifts were the very steep rise in interest rates in the United States and the accompanying steep appreciation of the U.S. dollar. In turn, dollar appreciation and high interest rates caused the dollar prices of internationally traded commodities, including oil, to fall. This combination of soaring interest rates and falling commodities prices caused international investors to reassess the debt-servicing capacity of borrower countries, such as Mexico.

One striking feature of the recent crises in emerging markets is that the typical international factors have not been present. In the crises of

3. Edwards (1996); Diaz-Alejandro (1988). 
1994 and 1995 (in Argentina, Mexico, Turkey, and Venezuela), international financial conditions were stable, U.S. interest rates were moderate, and the global trading system was open. Indeed, Mexico had just entered the North American Free Trade Agreement (NAFTA) with Canada and the United States. And economic reforms in Mexico and Argentina had generally led to widespread enthusiasm for these economies. Rudiger Dornbusch, Ilan Goldfajn, and Rodrigo Valdés assign heavy responsibility for the Mexican crisis to poor macroeconomic management within the country. In their view, the Achilles's heel of the Mexican and Argentine economies in 1994-95 was an overvalued exchange rate, a legacy of anti-inflation programs that had been centered on nominal exchange rate stability. In an alternative interpretation, Sachs, Aaron Tornell, and Andres Velasco argue that the overvaluation of the exchange rate played only an indirect role; more important was creditor panic. ${ }^{4}$

The East Asian crises of 1997 are even more remarkable. Not only were the international factors seemingly absent-with benign conditions in international financial markets, commodity markets, and the trading system-but the domestic factors that contributed to the crises in Mexico and Argentina did not apply either. None of the East Asian countries was in the aftermath of an anti-inflation program. Their real exchange rates were only mildly overvalued. Their overall debt carrying capacities did not seem to present imminent risks of default. Yet the crises hit with a vengeance.

\section{Self-Fulfilling Crises}

A closer look at the recent crises suggests a third category of explanation: intrinsic instability in international lending. ${ }^{5}$ Many observers have recently reached a similar conclusion regarding the Mexican episode and several other emerging markets crises that occurred before 1997. ${ }^{6}$ The basic notion is that international loan markets are prone to self-fulfilling crises, in which although individual creditors may act

4. Dornbusch, Goldfajn, and Valdés (1995); Sachs, Tornell, and Velasco (1996a, 1996b).

5. It should be noted that financial market instability also played a critical role in both the 1929 and 1982 crises.

6. See, for example, Calvo and Mendoza (1996); Eichengreen, Rose, and Wyplosz (1995); Kaminsky and Reinhart (1996). 
rationally, market outcomes produce sharp, costly, and fundamentally unnecessary panicked reversals in capital flows.

In this context, our preferred explanation turns on the critical distinction between illiquidity and insolvency. An insolvent borrower lacks the net worth to repay outstanding debts out of future earnings. An illiquid borrower lacks the ready cash to repay current debt-servicing obligations, even though this borrower has the net worth to repay the debts in the long term. A liquidity crisis occurs if a solvent but illiquid borrower is unable to borrow fresh funds from capital markets in order to remain current on debt-servicing obligations. Because the borrower is solvent, capital markets could, in principle, provide new loans to repay existing debts, with the expectation that both old and new loans would be fully serviced. The unwillingness or inability of the capital market to provide fresh loans to the illiquid borrower is the nub of the matter.

The primary reason why markets might fail in this way is a problem of collective action. Suppose that each individual creditor is too small to provide all of the loans needed by an illiquid debtor. When these creditors as a group would be willing to make a new loan, but no individual creditor is willing to make a loan if the other creditors do not lend as well, a liquidity crisis results. One possible market equilibrium is that no individual creditor is willing to make a loan to an illiquid borrower precisely because each creditor (rationally) expects that no other creditor is ready to make such a loan.

Consider a simple illustration. Suppose that a borrower owes debt $D$ to a large number of existing creditors. The debt requires debt service of $\theta D$ in period one and debt service of $(1+r)(1-\theta) D$ in period two. The debtor owns an investment project that will pay off $Q_{2}$ in the second period, where $Q_{2} /(1+r)$ is greater than the present value of debt service payments $\theta D+[(1+r)(1-\theta) D] /(1+r)=D$. The debtor lacks the cash flow to repay $\theta D$, since the investment project only pays off in the second period. Moreover, if the debtor defaults, the loans repayments are accelerated (that is, demanded at once by each individual creditor). Therefore the investment project is scrapped, with a salvage value of $Q_{1}<D$. In that case, the repayment of the outstanding loan is shared among the existing creditors on a pro rata basis.

Typically, this solvent but illiquid borrower would borrow a fresh loan, $L$, in the first period, use it to repay $\theta D$, and service $(1-\theta) D$ 
$+L$ in the second period. Thus, with $L=\theta D$, the total repayment due in the second period is $(1+r) \theta D+(1+r)(1-\theta) D=(1+r) D$, which, by assumption, is less than $Q_{2}$. Suppose, however, that the most that each individual creditor can lend is $\lambda$, where $\lambda \ll D$. This restriction might result from prudential standards imposed on individual bank lenders, which limit their exposure to particular debtors. If only one lender is prepared to lend in the first period, the borrower will be forced to default, since it will not be able to service its debts in that period. The new creditor lending $\lambda$ in the first period would then suffer an immediate loss on its loans (indeed, it might receive nothing if repayments are ordered such that all of the preceding creditors have priority on repayment). A first period loan will require at least $n_{1}$ new lenders, where $n_{1}=\theta D / \lambda$.

There are clearly multiple rational equilibria in this situation. In the normal case, $n_{1}$ lenders routinely step forward, the existing debts are serviced, and future debts are also serviced. The investment project is carried to fruition. In the case of a financial crisis, each individual creditor decides not to lend, on the grounds that no other creditor is making loans. The debtor is pushed to default. The debt repayments are accelerated, the investment project is scrapped with sharp economic losses, since the salvage value $Q_{1}$ is less than $Q_{2} /(1+r)$. And each individual creditor thus feels vindicated in its decision not to lend; after all, the debtor immediately defaults.

In the aftermath of the debt crisis among developing countries in 1982, Sachs and Richard Cooper sketched a simple model of this sort. ${ }^{7}$ Douglas Diamond and Philip Dybvig have offered a much more complete theory along these lines in the context of banking institutions. ${ }^{8}$ These authors seek to explain bank runs, in which depositors en masse suddenly demand withdrawals of their sight deposits and thereby push the bank into insolvency. In the model, the bank receives deposits in period zero from a large number of small depositors. The bank then lends the money for a long-term project coming due in period two. If all of the depositors demand immediate withdrawals of bank deposits in period one, the bank must call in the loan on the long-term investment. The investment project must then be terminated and sold for its

7. Sachs (1984); Cooper and Sachs (1985).

8. Diamond and Dybvig (1983). 
salvage value in period one. The bank, moreover, is presumably forced into liquidation if the salvage value of the investment is insufficient to cover the withdrawals.

A panic among depositors is therefore one rational equilibrium. If the depositors run, thereby bringing down the bank, they will lose part of the value of their deposits - and thus confirm their initial motivation to run from the bank. The run occurs not when depositors fear that the bank has made a bad investment decision, but when individual depositors fear that other depositors are withdrawing their money from the bank, thereby driving the bank into illiquidity and eventual liquidation. If depositors must get their money out of the bank on a first come, first served basis, each will have an incentive to be first in the queue for early withdrawals in the event of a generalized panic.

Diamond and Dybvig's paper is particularly insightful because it also addresses the question of why, if banks are such fragile institutions, they exist at all. The authors' answer is that a bank transforms maturities (that is, borrows short and lends long) in order to provide liquidity services for its depositors, who, individually, are not sure whether they will need to withdraw funds in the first period or the second period to meet their idiosyncratic consumption needs. If there is individual uncertainty over the timing of withdrawals but low aggregate uncertainty (that is, the bank can generally forecast the overall demand for withdrawals in the first period), then the bank can provide liquidity services by taking on short-term deposits and lending them long term. The only problem arises in the unlikely case that depositors panic, not because they need the money in the first period, but because the other depositors are also panicking.

The illiquidity-insolvency model is one of two main approaches to explaining herd behavior in financial markets-that is, cases where creditors act on the basis of the actions of other creditors, not on the basis of the debtor's fundamentals, as perceived by the individual investor. Alternatively, Abhijit Banerjee, Frederic Mishkin, Joseph Stiglitz and Andrew Weiss, and others have explored in detail the possible role of asymmetric information among creditors as a cause of market instability. ${ }^{9}$ One basic implication of the assumption of asymmetric information is that each individual creditor may rationally respond more to

9. Banerjee (1992); Mishkin (1991); Stiglitz and Weiss (1981). 
the actions of other creditors-now taken as signals - than to private information. Banerjee, for example, gives an example in which it is rational, but socially inefficient, for each decisionmaker to discard private information and base actions purely on the actions of earlier movers in a queue. The result is socially inefficient in the sense that it would be Pareto improving for each investor to ignore the actions of the others when making an individual decision.

\section{Mexico and Argentina, 1994-95}

In the light of the above discussion we turn briefly to the Mexican and Argentine crises, since they provide an invaluable backdrop for the Asian crises. The Mexican crisis actually proceeded in two stages. ${ }^{10} \mathrm{In}$ early 1994 foreign investors became wary, as a result of election-year instability. Capital inflows into Mexico dropped sharply in the second quarter of 1994, raising the threat of currency depreciation and slower growth. Probably because this was an election year, the Bank of Mexico expanded domestic credit in response. It also continued to peg the exchange rate, after an initial modest depreciation. The result was a steady decline in reserves, from around \$28 billion in February 1994 to only $\$ 10$ billion in early December 1994 . After the change of government in early December, rumors of a devaluation started to fly. Reserves plummeted further in mid-December, reaching around $\$ 6$ billion at their nadir. The currency was devalued over December 19 to 22, and then allowed to float.

The second stage of the Mexican crisis began immediately after the devaluation. International and domestic creditors started to realize that the Mexican government was due to repay around $\$ 28$ billion of shortterm dollar-denominated debts (tesobonos) within the following few months, but had only around $\$ 6$ billion of reserves. Suddenly, Mexico was unable to borrow fresh funds to service this debt. The government found itself solvent but illiquid. Its solvency was reflected by the fact that $\$ 28$ billion represented only around 10 percent of Mexico's precrisis GDP, and therefore was not a crushing debt burden. Moreover, the budget was roughly in balance.

Thus the Mexican government was pushed to the edge of default in

10. For a more complete discussion, see Sachs, Tornell, and Velasco (1996a); Edwards (1998). 
Figure 1. Real GDP Growth Rates, Argentina and Mexico, 1991-97

Percent

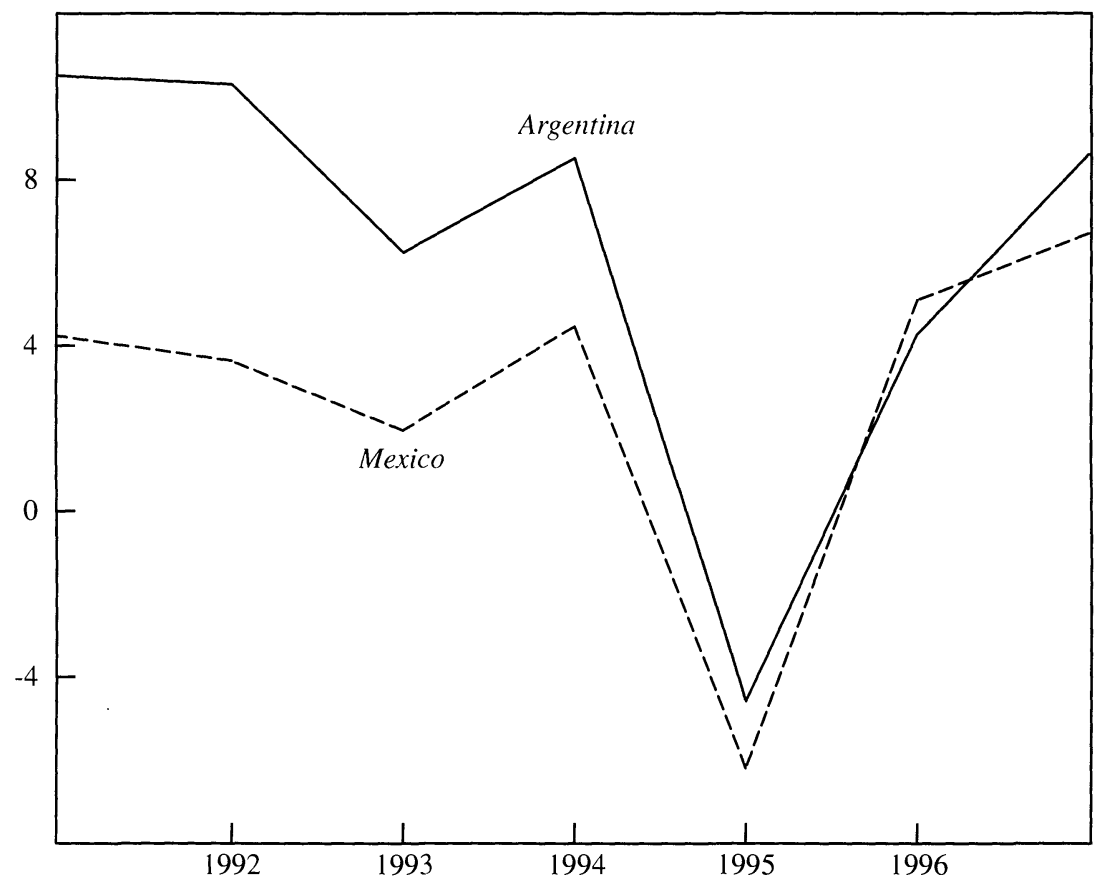

Source: Data for 1991-96 are from World Bank. World Development Indicutors, available on CD-ROM; and for 1997, from Economist, March 7. 1998, p. 114.

early 1995. In the event, the United States and the IMF led an emergency international loan to Mexico; although no individual private sector creditor could provide the amount of refinancing needed, official creditors could provide such large sums. The Mexican government used the loan to retire tesobonos and was able to repay the loan ahead of schedule, in 1996.

The patterns of macroeconomic adjustment in Mexico between 1993 and 1997 are telling. As shown in figure 1, Mexican GDP growth collapsed in 1995 but recovered strongly in 1996 and 1997. Figure 2 plots stock prices in Mexico over 1990-97. (Both figures also show data for Argentina, which is discussed below.) Table 2 shows that portfolio and other private investment flows also tumbled in 1994 and 1995 but quickly recovered in 1996 and 1997 . Notably, foreign direct 
Figure 2. Quarterly Stock Prices in Dollars, Argentina and Mexico, 1990-97a

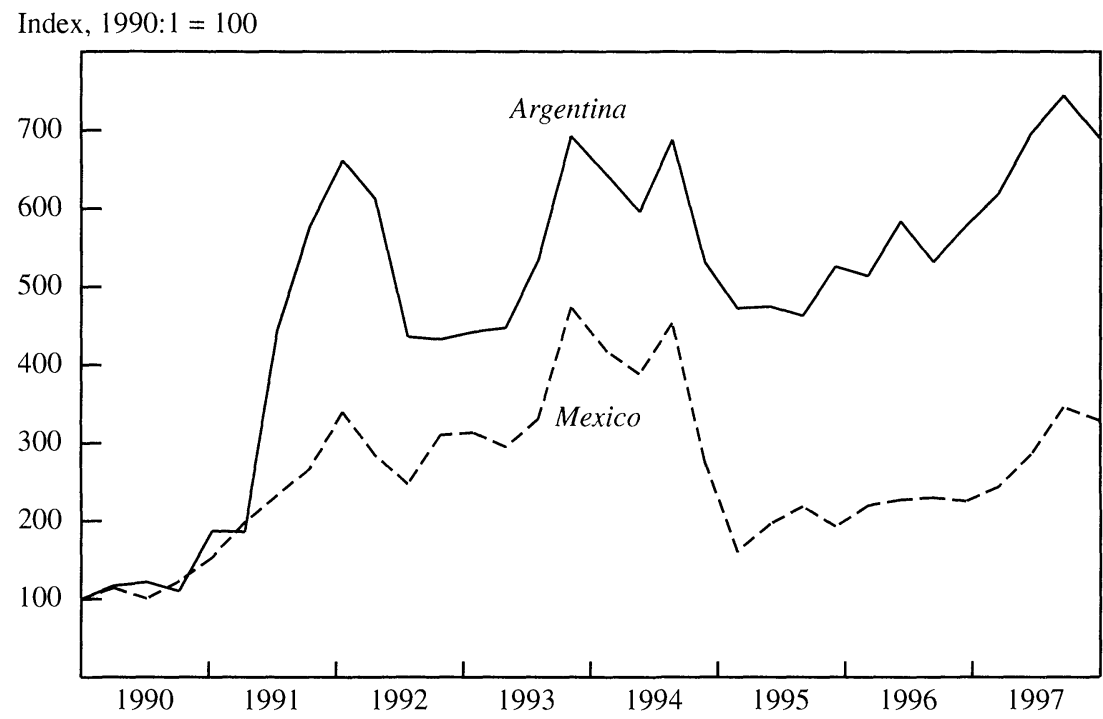

Source: Datastream's online service.

a. Refers to the main stock index in each country. Quarterly data cover 1990:1 to 1997:4, and tic marks fall between the fourth quarter of one year and the first quarter of the next.

investment was much more stable than portfolio investments. The real exchange rate depreciated sharply in late 1994 and further in 1995, but appreciated in 1996 and 1997. The stock market collapsed in the fourth quarter of 1994, but recovered sharply in 1996 and 1997. In short, Mexico suffered a deep, sharp shock without lasting effects. The episode has the hallmarks of a crisis that did not need to happen, in that it does not appear to have been justified by fundamental factors.

The Argentine crisis followed in the wake of the Mexican crisis. Even though the economy was performing strongly in 1994 and early 1995, domestic and foreign investors became skittish about Argentina's commitment to a pegged exchange rate and began to withdraw funds from its banks in the aftermath of the Mexican collapse and in anticipation of the May 1995 elections in Argentina. The withdrawals turned into a panic: there was a mass exodus of depositors and creditors from Argentine commercial banks. The banks were pushed to the brink of illiquidity and default. Argentina escaped full-fledged collapse by means of an emergency international bailout loan that combined funds 


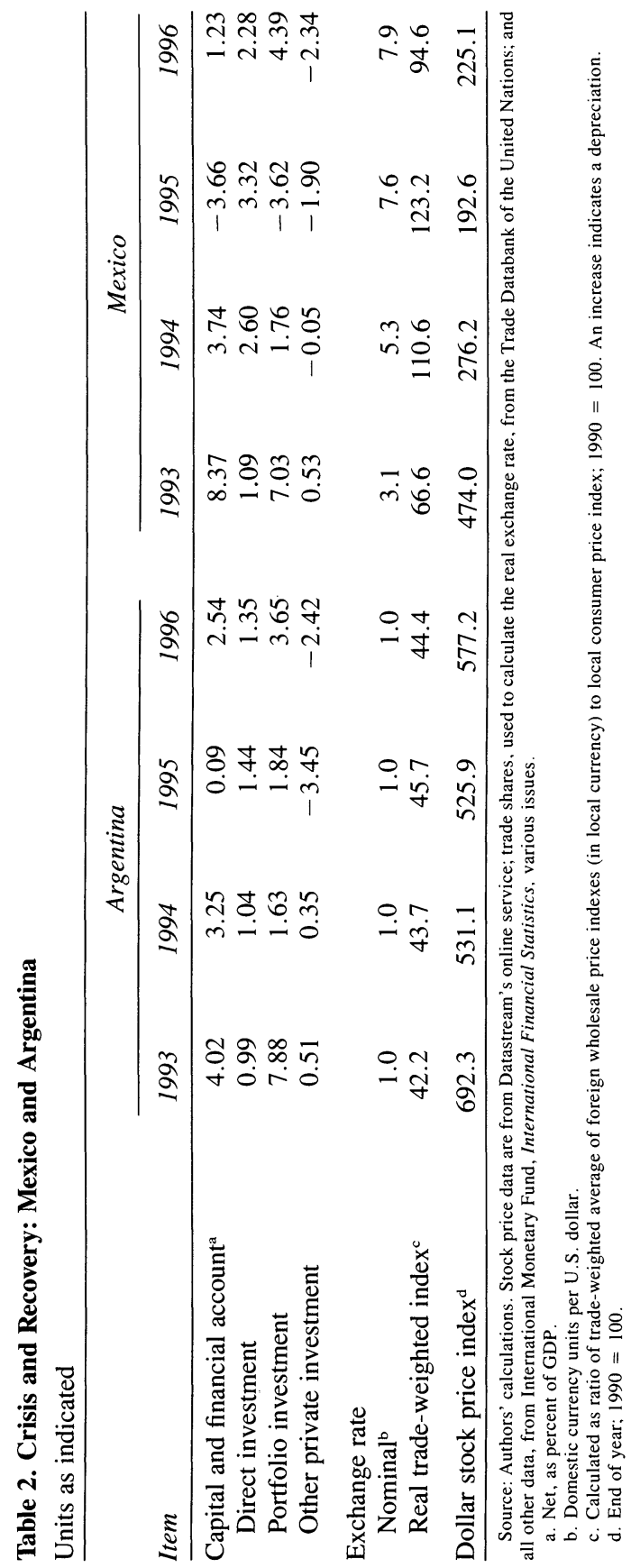


from the IMF, the World Bank, the Inter-American Development Bank, and some private creditors. As shown in figure 1, Argentina, like Mexico, suffered an abrupt collapse of GDP in 1995, followed by a rather swift recovery in 1996 and 1997. Also like Mexico, capital outflows in 1995 turned into net capital inflows in 1996-97. Once again, foreign direct investment was much more stable than other kinds of capital flows.

Mexico and Argentina were vulnerable to crisis because both were illiquid, in the sense that short-term liabilities to foreigners exceeded short-term assets. As a simple measure of illiquidity, for several emerging markets we compare short-term debts owed to international banks with foreign exchange reserves held by the central bank. The results are presented in table 3. The table illustrates clearly that for both Mexico and Argentina, this ratio had reached a vulnerable range in 1994. Interestingly, the nature of the debts differed markedly in the two countries, though the economic outcomes were similar. In the case of Mexico, the total debts owed to international banks were divided among the major domestic sectors as follows: government, 41 percent; banks, 20 percent; and nonbank private sector, 39 percent. The tesobono crisis, in particular, was a crisis of public sector indebtedness. In Argentina, the breakdown of debts owed to international banks was quite different: government, 26 percent; banks, 22 percent; and nonbank private sector, 52 percent. In essence, in Mexico the creditor run was on the government; in Argentina, it was on the banking system. We show below that there has been similar variety in the recent Asian crises. In Indonesia, the international bank debts are mainly owed by the nonfinancial corporate sector; in Korea and Thailand, they are owed mainly by the financial sector.

\section{Why Domestic Capital Markets Are Less Prone to Panic}

Advanced economies have introduced mechanisms and institutions that limit the onset of self-fulfilling panics within the domestic economy. These lessons offer insights for understanding the nature of international crises.

The United States, for example, was long prone to banking crises that were heavily domestic in origin. Such crises occurred in 1873, 1893, and 1907. The last of these helped to bring about in 1913 the Federal Reserve Act, which established the Federal Reserve System, 


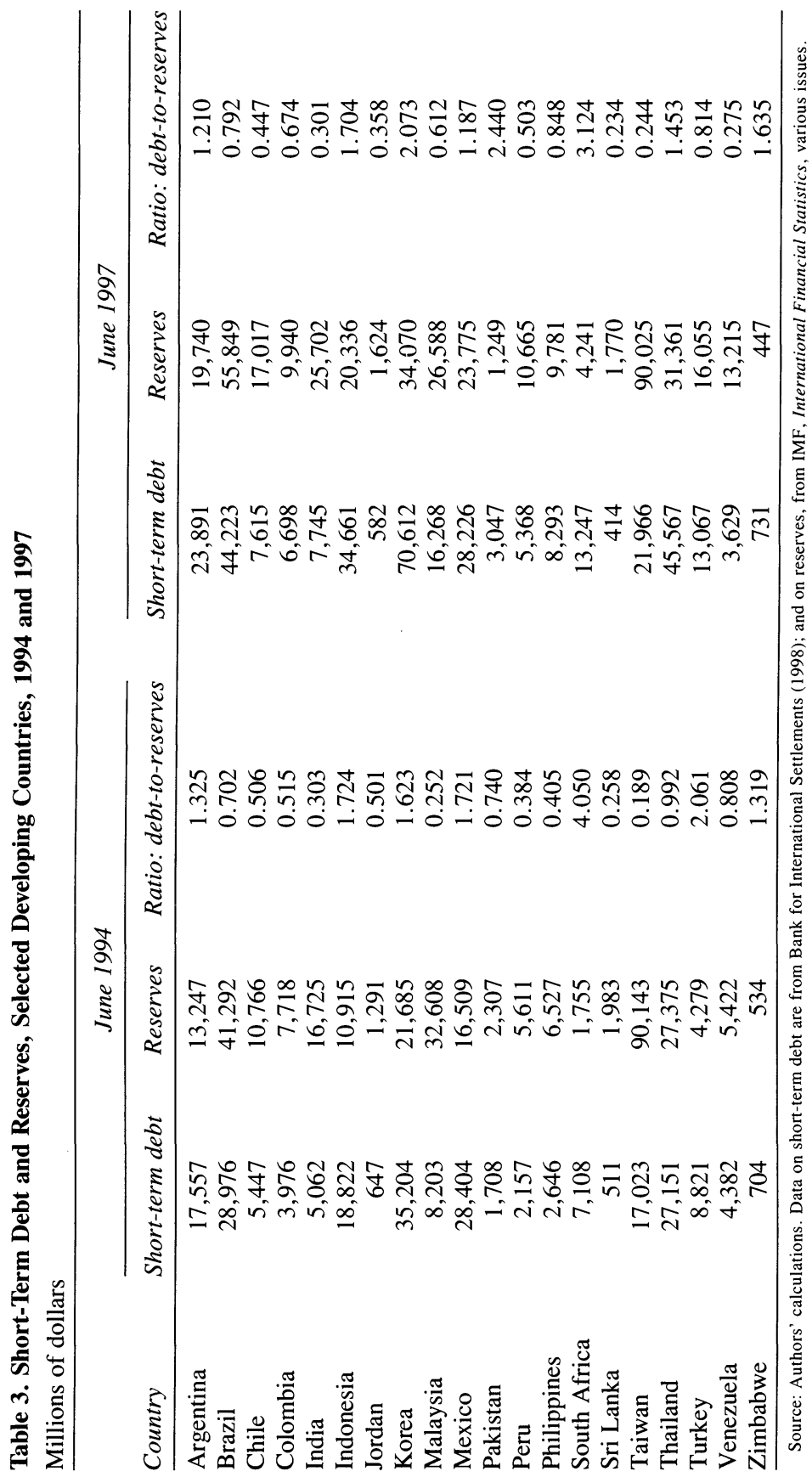


with the Federal Reserve as lender of last resort to member banking institutions in the event of creditor runs. The lender of last resort mechanism short-circuits a Diamond-Dybvig panic by providing the necessary funds, $L=\theta D$, to preserve short-term liquidity. The central bank, the ultimate issuer of high-powered money, is ostensibly free to issue credits as needed to illiquid but solvent financial institutions, in order to overcome such panics. The lender of last resort mechanism has two aspects. Most directly, it prevents outright default by providing liquidity on an elastic basis. More subtly, but perhaps more important, it can eliminate a self-fulfilling panic if depositors and creditors believe that the lender of last resort will provide the credits, $L$, as needed to forestall a banking collapse. Armed with that knowledge, there is no reason for an individual depositor to panic, even if others do so.

This mechanism has been used several times in recent years to ward off panic in the United States. When the stock market crashed in October 1987, the Federal Reserve Board responded by lowering interest rates and flooding the financial markets with increased liquidity to ensure the continued operation of the settlements. During the savings and loans crisis of the mid-1980s, when the government began to close down insolvent institutions, the Fed-with strong support from the White House-established a $\$ 100$ billion line of credit that would be made available to support the remaining institutions, thus limiting the potential for a bank run. And in 1991, when several major banks were probably insolvent, in that their liabilities exceeded their assets (if assets were marked to market), the Bush administration and the Federal Reserve Board took steps to keep them liquid until they had a chance to recapitalize.

The lender of last resort mechanism depends on the ability of this lender to issue sufficient credit to cover the liquidity needs of the cashstrapped borrowers - usually banks, but sometimes other financial institutions. ${ }^{11}$ When the loans are in domestic currency, the lender of last resort in principle is assured of the means to provide the necessary credits. When the loans are in foreign currency, however, the central bank may be unable to fulfill its role as lender of last resort due to a lack of adequate foreign exchange reserves. Thus in Mexico there was

11. For example, the Fed provided credit to several brokerage firms in the aftermath of the October 1987 stock market crash, in order to prevent a meltdown of the settlements system. 
no threat of outright default on peso-denominated Treasury bills, only on tesobonos. The lender of last resort function can also be frustrated by the assignment of monetary policy to goals other than the provision of liquidity. If the central bank is pegging the exchange rate or maintaining a gold standard, for example, it may be unwilling or unable by law to act as a lender of last resort, even though in principle it could issue the needed credits. Milton Friedman and Anna Schwartz and Barrie Wigmore argue convincingly that during the Great Depression, the Fed refused its role as lender of last resort in part for fear of pushing the United States off the Gold Standard, an eventuality which in fact transpired in $1934 .{ }^{12}$ And Argentina's vulnerability to financial panic in 1995 in part came from the widely recognized fact that the government was limited in its capacity to act as a lender of last resort because of the currency board arrangements, under which the Argentine peso is fixed at one to one with the U.S. dollar and the currency board has limited ability to issue credits that are not backed by dollar reserves.

In addition to the lender of last resort facility, domestic financial markets tend to have other bulwarks against self-fulfilling panics that are not available in the international context. Deposit insurance, backed ultimately by the central bank, is a crucial instrument for preventing bank runs by domestic depositors. Notably, the panic of 1933, which prompted the adoption of the Federal Deposit Insurance Act of 1934 and the creation of the Federal Deposit Insurance Corporation, was the last major banking panic in the United States. The effective functioning of deposit insurance, like the lender of last resort mechanism, depends on deposits being in domestic currency; countries with dollarized banking systems are often exposed to creditor runs even if some deposit insurance arrangements are in place, because such insurance tends to lacks adequate reserve funds, and therefore credibility.

Another bulwark against panic is a well-defined and relatively transparent system for managing bankruptcies, liquidations, and other forms of debt workouts. These types of institutional and legal mechanism do not exist in some countries, and they are often unworkable when creditors and debtors are residents of different countries. As noted above, part of the reason for a financial panic is the creditor grabrace, in which creditors flee from an illiquid or insolvent debtor, each trying to be the

12. Friedman and Schwartz (1963); Wigmore (1987). 
first one out of the door. This has very high costs: solvent and fundamentally healthy firms may be driven to default and eventual liquidation, debtors are unable to attract working capital, and so forth. Bankruptcy laws can forestall such adverse outcomes by bringing creditors and debtors together for orderly negotiations, rather than disorderly panics. They may also ensure adequate interim financing of illiquid enterprises in the process.

Many emerging markets lack the regulatory and legal infrastructure to support highly liberalized banking transactions, and they almost invariably lack the lender of last resort capacity to handle sudden shifts in depositor confidence. Trenchant observers, therefore, have long warned about the dangers of premature financial liberalization in such markets. Notably, Ronald McKinnon and Huw Pill stress the need to "restrain short-term capital flows, particularly those intermediated through the domestic banking system." ${ }^{13}$ We reach very similar conclusions below.

\section{East Asia's Growth Strategy: Was the Miracle a Mirage?}

One reason why the East Asian crisis came as such a surprise was the region's long track record of economic success. The broad outlines of that success are well-known. Figure 3 shows that in each of Malaysia, Indonesia, and Thailand, per capita income more than quadrupled between 1965 and 1996, and in Korea income rose seven-fold. Average incomes in these four countries have climbed from 10 percent of the U.S. average in 1965 to around 27 percent in the late 1990s. Table 4 shows that in Indonesia, Korea, Malaysia, and Thailand average life expectancy at birth rose from fifty-seven years in 1970 to sixty-eight years in 1995, and the adult literacy rate jumped from 73 percent to 91 percent. Notably, the benefits of economic growth were widely shared throughout the population. Incomes of the poorest fifth of the population grew just as fast as average incomes, and poverty rates fell substantially in each country. In Indonesia, for example, the share of the population living below the poverty line fell from 60 percent in the 1960 s to under 15 percent in 1996.

13. McKinnon and Pill (1996, p. 35). Another notable example is Diaz-Alejandro (1988). 
Figure 3. GDP per Capita, Selected Asian Countries, 1965-96

1985 dollars (logarithmic scale) ${ }^{\mathrm{a}}$

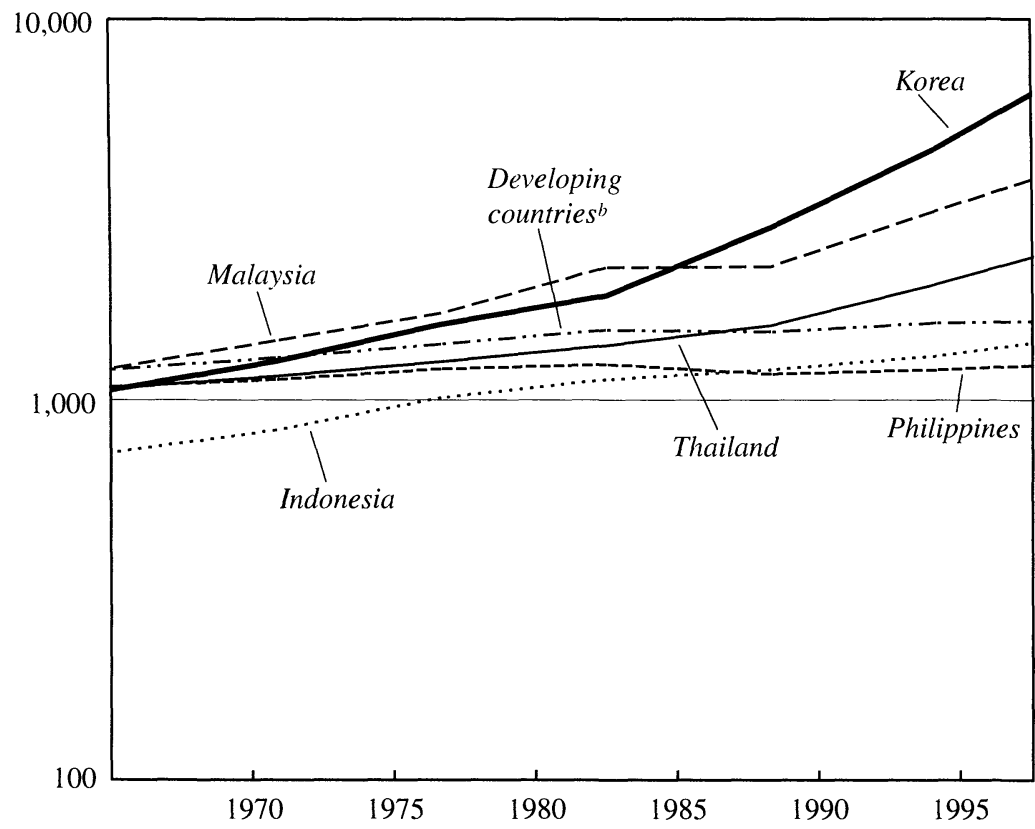

Source: GDP data for 1965-91 are from the Penn World Tables, mark 5.6, available on the worldwide web page of the National Bureau of Economic Research. For 1992-96, GDP levels are constructed by applying growth rates from World Bank, World Development Indicators (available on CD-ROM) to the respective 1991 GDP levels.

a. Conversion to dollars uses purchasing power parity (PPP) exchange rates.

b. Comprises eightly-five countries.

The origins of Asia's rapid growth have been hotly debated, and the discussion has taken on new energy with the onset of the financial crisis. Some observers now suggest that Asia's recent development is somehow a mirage - that it never really happened-or has been completely wiped out by the crisis. These views are obviously mistaken. There have been enormous gains in income levels, health, education, and general welfare in Asia during the last three decades, and these will not be dissipated by an extended recession. Even if the crisis is followed by several years of zero growth, standards of living will still be four times higher than they were one generation ago, and 50 percent higher than they were just one decade ago.

Others argue, more reasonably, that there may have been something in Asia's growth strategy that made the financial crash inevitable. As 
Table 4. Human Development Indicators, Selected Developing Countries, 1970 and 1995

Units as indicated

\begin{tabular}{|c|c|c|c|c|c|c|}
\hline Indicator & Indonesia & Korea & Malaysia & Philippines & Thailand & $\begin{array}{c}\text { Other developing } \\
\text { countries }^{\mathrm{a}}\end{array}$ \\
\hline \multicolumn{7}{|c|}{ Life expectancy ${ }^{\mathrm{b}}$} \\
\hline 1970 & 48 & 60 & 62 & 57 & 58 & 56 \\
\hline 1995 & 64 & 72 & 72 & 66 & 69 & 63 \\
\hline \multicolumn{7}{|c|}{ Literacy rate ${ }^{c}$} \\
\hline 1970 & 54 & 88 & 60 & 83 & 79 & 43 \\
\hline 1995 & 84 & 98 & 85 & 95 & 94 & 64 \\
\hline \multicolumn{7}{|c|}{ Income of poorest fifth ${ }^{d}$} \\
\hline $1970^{\mathrm{e}}$ & 392 & 303 & 431 & 218 & 361 & 731 \\
\hline $1990^{f}$ & 908 & 2071 & 1070 & 435 & 726 & 892 \\
\hline
\end{tabular}

Source: Authors' calculations. Data on life expectancy and literacy are from World Bank, World Development Indicators, available on CD-ROM. Data on income shares are from Deininger and Squire (1996); PPP income levels are from the Penn World Tables, mark 5.6, available on the worldwide web page of the National Bureau of Economic Research.

a. Average across countries. Set of countries and observation year vary, based on data availability. Averages for life expectancy includes 141 countries in 1970 and 131 in 1995; for literacy, 86 in 1970 and 108 in 1990; and for income. 20 countries in both 1970 and 1990

b. Life expectancy at birth.

c. Percent of population fifteen years and older.

d. Mean of poorest fifth, 1985 dollars, converted at PPP exchange rates.

e. 1976 for Indonesia, 1965 for Korea and the Philippines, and 1969 for Thailand.

f. 1988 for Korea and the Philippines, 1989 for Malaysia, and 1992 for Thailand.

we document elsewhere and summarize below, problems that began to emerge in the 1990s in both macroeconomic developments (capital inflows, real exchange rate appreciation) and microeconomic fundamentals (credit expansion, financial regulation and supervision) did contribute to the onset of the crisis. ${ }^{14}$ The argument that the crash was destined might be compelling if it were in fact true that the Asian "miracle" was the result of strong authoritarian government, a closeknit relationship between governments and corporate leaders in fostering heavy industry, or large state subsidies that helped exporters to gain market share. Although this view of the "Asian model of development" has gained widespread popularity during the past decade, it generally fails to hold up under close scrutiny. Such interpretations draw heavily on the distinctive experiences of Japan, Korea, and Taiwan, where governments did intervene heavily for a period, with directed credit, subsidies, and tariff protection to promote specific strategic industries. ${ }^{15}$

14. Radelet and Sachs (1998).

15. Amsden (1989); Wade (1990). 
But these kinds of interventionist policies clearly were not central to the successes of Hong Kong, Singapore, Thailand, China, Malaysia, or Indonesia. Hong Kong is probably the most open and least interventionist economy in the world; Singapore's interventions were very different from those in Northeast Asia; and industrial interventions in Southeast Asia and China have clearly hindered rather than helped growth. ${ }^{16}$ Even in Korea, where such industrial policies were most extensive, there is plenty of evidence that deeper strength came from the general orientation toward export-led growth.

We argue elsewhere that the core strategy in East Asia's industrial success was to integrate national with international production, not merely through export orientation, but also through specific institutions such as technology licensing, original equipment manufacturing, and export processing zones, which helped to attract export-oriented foreign investment. ${ }^{17}$ This strategy enabled economies to begin with lowtechnology manufactured export activities (for example, apparel, footwear, electronics assembly) and gradually upgrade to high-technology products, such as consumer electronics design and production. This outward-oriented industrialization strategy also depended fundamentally on four core macroeconomic policies that were pursued throughout the region: high rates of government and private saving; reliance on private ownership in the industrial sector; low inflation rates and restrained domestic credit policies; and convertible currencies, with low or zero black market premiums on foreign exchange. During the period of rapid foreign borrowing in the 1990s, the vast proportion of new lending supported increased investment spending rather than consumption.

One part of the process of long-term development is to strengthen financial institutions. As production processes become more complex and more deeply integrated with the world economy, a greater range of sophisticated and well-regulated financial services becomes important. Changes in firm ownership structure and financing arrangements require deeper capital markets for equities, bonds, bank loans, and other forms of financial intermediation. More capital-intensive production processes require low-cost long-run financing in order to be competitive, and a range of hedging instruments to protect against a variety of market risks.

16. Perkins (1994); Hill (1996); Asian Development Bank (1997).

17. Radelet, Sachs, and Lee (1997); Radelet and Sachs (1997). 
At least in part, the East Asian financial crisis has its roots in attempts at financial reform in the early 1990s that were aimed at upgrading financial institutions but in fact left individual economies exposed to the instabilities of international financial markets. For example, in Indonesia a series of financial deregulation packages led to tremendous expansion in the banking sector: the number of private banks (including foreign and joint venture banks) nearly tripled from seventy-four in 1988 to 206 six years later. ${ }^{18}$ The centerpiece of Thailand's effort to compete with Singapore and Hong Kong as a regional financial center was the now notorious Bangkok International Banking Facility (BIBF), introduced in 1992. The BIBF allowed for very rapid growth in the number of financial institutions that could borrow and lend in foreign currencies, both on- and offshore. In Korea, financial market reforms in the mid-1990s similarly opened the door to greatly expanded banking activity and increased the access of domestic banks to short-term international loans. ${ }^{19}$

In general, the rapid expansion in financial services was not matched by careful regulation and supervision. Regulatory reforms tended to be partial and incomplete. As a result of this piecemeal approach, reforms in one area often opened up loopholes in other areas, which firms were quick to exploit. ${ }^{20}$ Moreover, the huge expansion in banking activity would have made supervision much more difficult, even under the best of circumstances - and they were not the best. State-owned banks in Indonesia and Korea were regularly allowed to break many prudential regulations without penalty. As in numerous countries around the world, many banks were owned by politically well-connected individuals who used them to finance the operations of affiliated companies. In Indonesia, for example, almost every major corporations had its own bank, and the line between the two entities was often blurred.

Ironically, East Asia became vulnerable to external financial shocks in part because it attempted to reform its financial markets in a marketoriented manner. Those countries hit hardest by the crisis-like Mexico and Argentina in the early 1990s and Chile in the early 1980s-had all started, but had not completed, the process of financial market liberalization and reform. The reforms led to dramatic growth in the number

18. Cole and Slade (1996).

19. See Park (1998).

20. Cole and Slade (1996). 
of banks and their linkages to the international economy, which, in turn, increased the exposure of these economies to international financial shocks, mainly through the remarkable buildup of short-term debts. Countries with stronger financial systems (for example, Singapore and Hong Kong) had taken steps to redress inadequate regulations and poor supervision, and thus were less prone to a crisis. At the other end of the spectrum, countries that had not undertaken significant financial sector reforms (for example, China and Vietnam) were shielded by the fact that they had received much less short-term capital inflow in the early 1990s. Seen in this light, the crisis was not the inevitable result of an Asian capitalist model, but rather, an accident of partial financial reforms that exposed these economies more directly to the instability of international financial markets.

\section{The Onset of the Crisis}

In related work, we describe the onset of the East Asian crisis in detail. ${ }^{21}$ We point out that while the East Asian economies continued to achieve rapid economic growth in the 1990s, there were growing imbalances and weaknesses at both the microeconomic and macroeconomic levels. Most important, there was a rapid buildup of short-term external debt into weak financial systems - made possible both because East Asia's successful track record attracted foreign credits, and because partial financial market liberalization in the region opened new channels for the entry of foreign capital. The inflows led to appreciating real exchange rates, to a rapid expansion of bank lending, and in particular, to increasing vulnerability to a reversal in capital flows. When capital inflows did wane in late 1996 and early 1997, a series of missteps by Asian governments, market participants, the IMF, and the international community resulted in a financial panic. The crisis was much deeper than was either necessary or inevitable.

Several aspects of the buildup to the crisis are worth highlighting. First, annual capital inflows into the five crisis economies-Indonesia, Korea, Malaysia, the Philippines, and Thailand-averaged over 6 percent of GDP between 1990 and 1996. Capital inflows into Thailand 
averaged over 10 percent of GDP during the 1990s and reached a remarkable 13 percent of GDP in 1995 alone. In Malaysia, inflows averaged 9 percent of GDP between 1990 and 1996, jumping to over 15 percent of GDP for both 1992 and 1993 and then tapering off. While Thailand's inflows predominately represented borrowing by banks and financial institutions, the bulk of Malaysia's inflows were in the form of foreign direct investment, which is less prone to quick reversal. In Indonesia, inflows averaged a more modest 4 percent of GDP, mostly in the form of borrowing by private corporations.

Second. the East Asian governments maintained exchange rates with either very little variation (for example, Malaysia, Thailand, and the Philippines) or small, predictable changes (for example, Indonesia and Korea). In effect, the central banks absorbed the risks of exchange rate movements on behalf of investors, which helped to encourage capital inflows, especially with short maturity structures.

Third, exchange rates appreciated in real terms, as the capital inflows put upward pressure on the prices of nontradables. Real effective exchange rates appreciated by more than 25 percent in Indonesia, Malaysia, the Philippines, and Thailand between 1990 and early 1997; in Korea, the appreciation was about 12 percent. Note, however, that the real appreciations in Asia during the 1990s were relatively modest compared with those seen in other developing countries. Brazil and Argentina, for example, have had real exchange rate appreciations of more than 40 percent since 1990 .

Fourth, export growth, measured in current U.S. dollars, began to slow in the mid-1990s and then dropped sharply in 1996 in every country. In Thailand, exports actually fell in nominal dollar terms in 1996, while in Korea exports increased by only 3.7 percent. Several factors probably contributed to this pattern: the increasing overvaluation of the exchange rates, the appreciation of the Japanese yen against the dollar after 1994, the devaluation of the Chinese yuan in January 1994, the competitive effects of Mexico's participation in NAFTA and the devaluation of the Mexican peso, and the worldwide glut in semiconductor production.

Fifth, domestic bank lending expanded rapidly throughout the region. ${ }^{22}$ In Thailand, Korea, and Malaysia, banking claims on the private

22. See McKinnon and Pill (1996) for a formal analysis of the "overborrowing syndrome', in emerging markets. 
sector increased by more than 50 percent relative to GDP in seven years, reaching 140 percent of GDP in 1996. The Philippines, starting from a much lower base, recorded private credit growth of over 40 percent per year between 1993 and 1996. Only in Indonesia did credit growth remain at more modest levels - but in this case, private corporations were borrowing directly offshore. Much of the new lending was financed by the banks borrowing offshore. In Korea, the foreign liabilities of the banking system more than doubled from 4.5 percent of GDP in 1993 to 9.5 percent of GDP in mid-1997. In the Philippines, equivalent liabilities soared from 8.8 percent of GDP at the end of 1995 to an astonishing 21 percent of GDP just eighteen months later, in mid1997. The most extreme case was Thailand, where, after the introduction of the BIBF, the foreign liabilities of banks and financial institutions increased rapidly to over 28 percent of GDP by 1995 .

Sixth, a modestly increasing share of domestic bank lending was apparently used for real estate, property, and the purchase of equity funds. Official data on lending by sector show a small increase in loans for real estate, but nearly all market observers suggest that they understate the magnitude of these activities.

Finally, a rising share of foreign borrowing was in the form of shortterm debt. In particular, table 5 shows that by the end of 1996 shortterm debts to offshore banks in Korea, Thailand, and Indonesia had reached $\$ 68$ billion, $\$ 46$ billion, and $\$ 34$ billion, respectively. Indeed, these numbers understate total short-term liabilities, since nonbank finance (for example, bonds) is not included. The ratio of short-term debt to foreign exchange reserves in each of these three countries exceeded one after 1994. A ratio greater than one is not by itself sufficient to spark a crisis, as long as foreign creditors are willing to roll over their loans. However, it does indicate vulnerability to a crisis: once something sparks a withdrawal of foreign capital, each foreign creditor has an incentive to demand repayment quickly, since each one knows that there is not enough foreign exchange to repay them all.

It should be emphasized that these imbalances were centered in the private sector rather than in the government. Throughout the early 1990s, East Asian governments kept their budgets in surplus, maintained prudent levels of overall money growth, and kept inflation rates below 10 percent. In each country, government foreign debt actually declined (as a share of GDP) during the 1990s. 
Table 5. Debt to Foreign Banks and Foreign Exchange Reserves, Selected Crisis Countries, 1995-97

Billions of dollars

\begin{tabular}{|c|c|c|c|c|c|c|c|}
\hline \multirow[b]{2}{*}{$\begin{array}{l}\text { Year } \\
\text { and country }\end{array}$} & \multicolumn{4}{|c|}{ Debt by sector } & \multirow[b]{2}{*}{$\begin{array}{l}\text { Short-term } \\
\text { debt }\end{array}$} & \multirow[b]{2}{*}{ Reserves } & \multirow[b]{2}{*}{$\begin{array}{c}\text { Ratio: short-term } \\
\text { debt-to-reserves }\end{array}$} \\
\hline & Total & Banks & Public & $\begin{array}{c}\text { Nonbank } \\
\text { private }\end{array}$ & & & \\
\hline \multicolumn{8}{|l|}{ End 1995} \\
\hline Indonesia & 44.5 & 8.9 & 6.7 & 28.8 & 27.6 & 14.7 & 1.9 \\
\hline Malaysia & 16.8 & 4.4 & 2.1 & 10.1 & 7.9 & 23.9 & 0.3 \\
\hline Philippies & 8.3 & 2.2 & 2.7 & 3.4 & 4.1 & 7.8 & 0.5 \\
\hline Thailand & 62.8 & 25.8 & 2.3 & 34.7 & 43.6 & 37.0 & 1.2 \\
\hline Korea & 77.5 & 50.0 & 6.2 & 21.4 & 54.3 & 32.7 & 1.7 \\
\hline Total & 209.9 & 91.3 & 20.0 & 98.4 & 137.5 & $\ldots$ & $\ldots$ \\
\hline \multicolumn{8}{|l|}{ End 1996} \\
\hline Indonesia & 55.5 & 11.7 & 6.9 & 36.8 & 34.2 & 19.3 & 1.8 \\
\hline Malaysia & 22.2 & 6.5 & 2.0 & 13.7 & 11.2 & 27.1 & 0.4 \\
\hline Philippines & 13.3 & 5.2 & 2.7 & 5.3 & 7.7 & 11.7 & 0.7 \\
\hline Thailand & 70.2 & 25.9 & 2.3 & 41.9 & 45.7 & 38.7 & 1.2 \\
\hline Korea & 100.0 & 65.9 & 5.7 & 28.3 & 67.5 & 34.1 & 2.0 \\
\hline Total & 261.2 & 115.2 & 19.6 & 126.0 & 166.3 & $\ldots$ & $\ldots$ \\
\hline \multicolumn{8}{|l|}{ Mid-1997 } \\
\hline Indonesia & 58.7 & 12.4 & 6.5 & 39.7 & 34.7 & 20.3 & 1.7 \\
\hline Malaysia & 28.8 & 10.5 & 1.9 & 16.5 & 16.3 & 26.6 & 0.6 \\
\hline Philippines & 14.1 & 5.5 & 1.9 & 6.8 & 8.3 & 9.8 & 0.8 \\
\hline Thailand & 69.4 & 26.1 & 2.0 & 41.3 & 45.6 & 31.4 & 1.5 \\
\hline Korea & 103.4 & 67.3 & 4.4 & 31.7 & 70.2 & 34.1 & 2.1 \\
\hline Total & 274.4 & 121.8 & 16.7 & 136.0 & 175.1 & $\ldots$ & $\ldots$ \\
\hline \multicolumn{8}{|l|}{ Addendum } \\
\hline \multicolumn{8}{|l|}{ Mexico } \\
\hline End 1994 & 64.6 & 16.7 & 24.9 & 22.8 & 33.2 & 6.4 & 5.2 \\
\hline End 1995 & 57.3 & 11.5 & 23.5 & 22.3 & 26.0 & 17.1 & 1.5 \\
\hline
\end{tabular}

Source: Authors' calculations. Data on debt are from Bank for International Settlements (1998); and on reserves, from IMF, International Financial Statistics, various issues.

\section{Withdrawal of Capital and the Financial Panic}

In early 1997 pressure began to mount in both Korea and Thailand. In Korea, Hanbo steel declared bankruptcy in January, leaving \$5.8 billion in debts. In the next few months, both Sammi Steel and Kia Motors faced similar difficulties. These problems put increasing pressures on merchant banks, which had borrowed offshore to lend to these chaebol (conglomerates), and began to raise concerns about the finan- 
cial strength of other chaebol. In Thailand, property prices fell in late 1996, and a major property developer, Somprasong Land, was unable to meet a foreign debt payment due on February 5, 1997. These developments provided the first clear indication that financing companies heavily exposed to the Bangkok property market were in trouble. The baht came under attack in late 1996, and twice again in the early months of 1997. In March the Thai government promised to buy $\$ 3.9$ billion in bad property debt from finance companies, but quickly reneged. As evidence grew of the fragile condition of the property sector and financial institutions, speculation mounted that foreign exchange reserves were dwindling and that the government would have to float the baht. The government protested that it would neither allow Finance One, the largest financial institution, to go under nor float the baht, but to no avail. By late June, Thailand had sharply reduced its liquid foreign exchange reserves, and the baht was cut loose on July 2 .

Foreign creditors reacted by withdrawing capital from countries around the region, and exchange rates came under intense pressure. By early September, the currencies of Indonesia, Malaysia, the Philippines, and Thailand had each fallen by 20 percent or more. As the currencies fell and capital flows reversed, several forces came into play to create a self-reinforcing spiral into panic. First, creditors made little effort to distinguish among these Southeast Asian countries in the early stages; they assumed that if Thailand was in trouble, the others could not be too far behind. Second, as exchange rates depreciated and the domestic currency costs of servicing foreign debts rose, foreign creditors became more reluctant to extend new loans and roll over existing loans. Domestic debtors had to buy foreign exchange to retire these debts, putting more pressure on exchange rates, which, in turn, further encouraged creditors not to roll over loans. Third, domestic debtors, many of whom had not hedged their foreign exchange exposures, began to purchase foreign exchange to try to close their positions. Fourth, the major ratings agencies belatedly downgraded countries in the region, triggering further withdrawals by creditors. Fifth, as we discuss in more detail below, the initial responses of governments in the region as well as the international community added fuel to the fire. As international confidence in their initial strategies waned and it became clear that the economic contractions in the region would be much larger than originally thought, creditors withdrew even more funds. 


\section{Initial Responses}

It is likely that had the Thai government reacted differently to the fall in land and stock prices and the growing fragility of the financial institutions in late 1996 and early 1997, that country would have escaped a serious crisis. Contagion to the rest of the region would also have been avoided. Despite the fall in property prices, the warnings of investment analysts, and the large infusions of money to ailing banking institutions, the government staunchly maintained the exchange rate peg of the baht to the U.S. dollar, thereby leading to a massive loss of reserves. By the time the central bank floated the baht, it had spent considerable foreign exchange reserves in defense of the currency and had committed large amounts of foreign exchange to forward purchases of baht. ${ }^{23}$ Moreover, it had spent billions of dollars in baht to prop up failed banking institutions, without taking fundamental steps toward their closure, merger, or rehabilitation. ${ }^{24}$ As a result, the country became extremely vulnerable to investor panic, because investors recognized that Thailand's available foreign exchange reserves had fallen far below the outstanding short-term debts owed to international banks.

Once the crisis began to spread, other countries also made mistakes that accelerated the capital withdrawals. Malaysian prime minister Mohamed Mahathir's harsh comments about foreign investors and his threats of banning foreign currency trading are prime examples. Thailand and Malaysia imposed mild capital controls. Malaysia announced it would establish a fund to support stock prices, but abandoned the plan a few days later. Korea seemed to be boldly facing some of its problems by allowing some chaebol to go bankrupt, but it inexplicably spent down its reserves in a desperate attempt to defend the Korean won in October and November.

23. The Thai government reportedly spent $\$ 16$ billion in defense of the baht in late 1996 and early 1997, and by June had an additional \$23 billion in forward swaps outstanding. It did not stand to lose all of the $\$ 23$ billion, but rather, the difference between the forward rates and the future spot rates at the time when the forward positions would be liquidated. Moreover, some of the forward contracts were dated as much as one year ahead, so that the losses would not be realized immediately.

24 . The government reportedly injected between $\$ 3$ billion and $\$ 4$ billion into the Bangkok Bank of Commerce after seizing it in 1996. The Bank of Thailand also announced that it spent 500 billion baht (about $\$ 19.3$ billion) to keep ninety-one finance companies afloat in 1996 and early 1997, of which it expected to recover 100 billion baht at most. 
Ironically, Indonesia initially was widely praised for its handling of the crisis, as it first widened the trading band on the rupiah and then floated the currency in August. ${ }^{25}$ It resisted the temptation to spend reserves, eased rules governing foreign ownership of stocks, and announced that it would postpone over one hundred investment projects. It retracted that decision for several large projects, however, and then later postponed them again. These on-again and off-again pronouncements, and the requirement that state enterprises pull their large deposits out of the banking system, which sharply increased interest rates, frayed nerves and encouraged further withdrawals of foreign funding.

The IMF programs, rather than inspiring confidence, seem to have accelerated the flight of currency from the region, despite pledges of more than $\$ 100$ billion in emergency funds to Thailand, Indonesia, and Korea. The initial programs focused on fiscal deficits, high interest rates, restrictive money growth, and the immediate closures of insolvent financial institutions. But these programs in Thailand, Indonesia, and Korea were discarded within months - three weeks, in the case of Korea. In each country, although the signing of the IMF agreement was greeted by brief enthusiasm, it was followed by the continued depreciation of the exchange rate and declining stock prices. The first sign of an end to the currency free-falls came only on December 24, 1997, when the international community initiated a different approach to the problem based on debt restructuring, accelerated disbursements of international funding, and more comprehensive and rational restructuring of the financial sector.

\section{Alternative Approaches to Explaining the Crisis}

We discussed above three broad categories of explanations for the East Asian crisis: shifts in international market conditions; growing weaknesses and mismanagement in the Asian economies; and instabilities intrinsic to the international capital markets. In this section we apply this tripartite framework, with an eye toward proper policy responses and guidelines for preventing or containing future crises. There

25. See, for example, Douglas Appell, "In Battle for Investors, This Is No Contest: Amid a Crisis, Indonesia Opens Up and Thrives as Malaysia Stumbles,' Asian Wall Street Journal, September 5, 1997, p. 5. 
are certainly candidate explanations in each category; the question is one of degree. While we believe that shifts in international conditions and mismanagement (and corruption) played some role, there is also clear evidence that intrinsic capital market instability is a key factor in the depth, severity, extent, and simultaneity of the region's problems.

\section{Shifts in International Market Conditions}

On the most general level, international market conditions were benign or favorable before the onset of the East Asian crisis. U.S. interest rates remained low. World commodity markets were relatively stable. Risk premiums on loans to emerging markets were falling. The growth in total volume of international trade was strong, if a little bit slower in the aggregate in 1996 and 1997 compared with 1993-95. World export volumes grew by 6 percent in 1996, down slightly from the 9 percent recorded in 1994 and 1995 but still above the world average for the early $1990 \mathrm{~s} .{ }^{26}$

Despite this favorable environment, several hypotheses about the crisis center around unexpected international shocks to the Asian economy. On closer inspection, however, it appears that these shocks made at best a modest contribution. Specifically, such arguments focus on the collapse of export growth in 1996 in Thailand and Korea, as well as slowing export growth in Malaysia and Indonesia. Table 6 shows change in exports and imports in 1995 and 1996 for selected countries. The most extreme case was Thailand, where the dollar value of exports actually fell 1 percent in 1996, after two years of growth in excess of 20 percent. Korea's exports grew by just 4 percent in 1996, down from 30 percent in 1995; and Malaysia's grew by only 6 percent in 1996, down from 26 percent the previous year. Indonesia's situation was a little different: in 1996 it registered 10 percent export growth, about the same as in the previous three years-but well below the 1990-92 average. Only the Philippines registered substantial export growth in 1996, at 17 percent.

From table 6 it can be seen that the division of the fall in dollar export earnings between volume and unit value differs widely across countries (although the usual strong caveats about the poor quality of

26. In value terms, world exports grew just 4 percent in 1996, after jumping by an average of 17 percent in 1994 and 1995; International Monetary Fund (1997c). 
Table 6. Export and Import Growth Rates, Selected Countries, 1995-96a

Percent

\begin{tabular}{|c|c|c|c|c|c|c|}
\hline \multirow[b]{2}{*}{ Country } & \multicolumn{2}{|c|}{ Value growth } & \multicolumn{2}{|c|}{ Volume growth } & \multicolumn{2}{|c|}{ Unit value change } \\
\hline & 1995 & 1996 & 1995 & 1996 & 1995 & 1996 \\
\hline \multicolumn{7}{|l|}{ Exports } \\
\hline China & 22.9 & 1.6 & 15.3 & 8.3 & 6.6 & -6.2 \\
\hline India & 22.7 & 7.4 & 22.4 & 16.9 & 0.2 & -8.1 \\
\hline Hong Kong & 14.8 & 4.0 & 1.9 & -8.6 & 12.6 & 13.8 \\
\hline Korea & 30.3 & 3.7 & 24.0 & 19.1 & 5.0 & -12.9 \\
\hline Singapore & 22.1 & 5.7 & 15.7 & 6.3 & 5.6 & -0.6 \\
\hline Indonesia & 13.4 & 9.7 & 10.3 & 4.8 & 2.8 & 4.7 \\
\hline Malaysia & 26.0 & 5.8 & 15.6 & 13.6 & 9.0 & -6.9 \\
\hline Philippines & 31.6 & 16.7 & 17.0 & 18.8 & 12.4 & -1.8 \\
\hline Thailand & 25.1 & -1.3 & 14.2 & -0.7 & 9.5 & -0.6 \\
\hline Argentina & 33.9 & 13.6 & 17.8 & 3.2 & 13.7 & 10.0 \\
\hline Mexico & 40.3 & 22.6 & 24.5 & 14.7 & 12.7 & 6.9 \\
\hline Poland & 34.3 & 6.8 & 30.8 & 6.9 & 2.7 & -0.1 \\
\hline \multicolumn{7}{|l|}{ Imports } \\
\hline China & 11.6 & 7.6 & 15.1 & 16.4 & -3.0 & -7.5 \\
\hline India & 28.6 & 8.3 & 23.6 & 18.9 & 4.0 & -8.9 \\
\hline Hong Kong & 19.2 & 3.0 & 13.6 & 4.0 & 4.9 & -1.0 \\
\hline Korea & 32.0 & 11.3 & 21.2 & 11.9 & 8.9 & -0.6 \\
\hline Singapore & 21.3 & 5.5 & 13.0 & 6.4 & 7.3 & -0.9 \\
\hline Indonesia & 27.0 & 5.7 & 17.4 & 10.7 & 8.2 & -4.6 \\
\hline Malaysia & 30.5 & 0.9 & 23.4 & 17.7 & 5.8 & -14.3 \\
\hline Philippines & 25.7 & 20.4 & 14.6 & 24.2 & 9.7 & -3.0 \\
\hline Thailand & 30.0 & 3.8 & 15.9 & -3.6 & 12.1 & 7.7 \\
\hline Argentina & -6.5 & 18.1 & -17.5 & 25.2 & 13.3 & -5.7 \\
\hline Mexico & -23.1 & 30.4 & -14.9 & 20.8 & -9.6 & 8.0 \\
\hline Poland & 35.9 & 27.8 & 24.5 & 28.9 & 9.1 & -0.8 \\
\hline
\end{tabular}

Source: Authors' calculations. Data on values are from IMF, International Financial Statistics, various issues; and on volumes, from Bank for International Settlements (1997).

a. Table uses dollar values of exports and imports.

trade volume and unit value data apply). In Korea and Malaysia, export volumes apparently continued to grow rapidly-at 19 percent and 14 percent, respectively-but unit values fell sharply. In Thailand, by contrast, the volume of exports stagnated in 1996, and there was little change in unit values. Indonesia is an intermediate case, with much slower volume growth than in Korea or Malaysia, but greater than in Thailand.

One hypothesis holds that there is a new global glut in labor-intensive manufactured exports, precisely the kind of exports that fueled East 
Asia's growth in the past generation. ${ }^{27}$ Such a glut would be reflected in slower export earnings in countries with labor-intensive manufacturing and declining terms of trade for labor-intensive products, such as apparel, footwear, and consumer electronics. World prices for manufactured exports fell about 2 percent in $1996 .{ }^{28}$ Semiconductors were hit especially hard, with prices estimated to have fallen by as much as 80 percent in 1996, before they began to rebound. ${ }^{29}$ The rapid growth in electronics production in East Asia, coupled with the addition of China and Mexico to these markets (see below), probably created excess productive capacity and contributed to the decline in prices. This provides a plausible explanation for the fall in unit values of Korean and Malaysian exports, which are substantially composed of electronics products.

A second, closely related, argument suggests that the economic growth of China may have dramatically shifted export-oriented production away from Southeast Asia-as India's growth might perhaps do in the future. From a mere $\$ 20$ billion twenty years ago, China's exports had grown to $\$ 150$ billion in 1996 , making it the eleventh largest exporter in the world. Manufactured exports grew by more than 22 percent per year, in nominal dollar terms, between 1990 and 1995. As Park and others point out, competition from China could be expected to exert downward pressure on both wages and export growth in the rest of the region. ${ }^{30}$ Indeed, some observers have directly linked the 1996 decline in Southeast Asian exports to China's effective 50 percent devaluation of the yuan in 1994 .

Chinese firms compete directly against other firms in the region in textiles, apparel, and electronics, and in some products they are clearly gaining market share. Consider the group of six countries comprising China and the five crisis economies-Indonesia, Korea, Malaysia, the Philippines, and Thailand. Of total exports from this group, China's share of garment exports surged from 37 percent in 1990 to 60 percent in 1996, and its share of electronics exports jumped from 12 percent to 18 percent over the same period. Nevertheless, its overall role in the 1996 slowdown in Southeast Asian exports was probably modest at

27. See, for example, Radelet, Sachs, and Lee (1997).

28. International Monetary Fund (1997c).

29. Bank for International Settlements (1997).

30. Park (1996). 
best. China's export growth also plunged in 1996, registering a rather anemic rate of just 1.6 percent. Its textile exports fell 12 percent, and its garment exports grew by only 4 percent. China's share of total manufactured exports from this group of countries was 32 percent in 1996, down 2 percentage points from 1994 and exactly the same as in 1992. In other words, the emergence of China did little to displace overall manufactured exports from the rest of the region between 1992 and 1996. The impact of the 1994 devaluation of the yuan was probably also relatively limited, since its real effect was substantially eroded through the gradual nominal appreciation of the yuan and two years of inflation averaging 20 percent, compared with an average of 6 percent in the five crisis countries.

We suggest a third hypothesis, relating to the United States, which remains the single most important market for the crisis countries of Asia. The passage of NAFTA and the dramatic surge of Mexico's exports, especially in the wake of the 1994 peso devaluation, may have resulted in intense new competition for East Asia. Mexico's total exports soared from $\$ 52$ billion in 1993 to $\$ 96$ billion in 1996, with gains in several areas that directly compete with East Asian exports, including electronic machinery, apparel, and automotive components. As with China, however, while the effect was probably important in certain sectors, the overall impact on Asian exports was moderate.

Table 7 shows export growth rates and shares of total exports for the five Asian crisis economies, China, and Mexico. Between 1990 and 1996, China's share of total exports from these countries grew slightly, from 25.8 percent to 27.8 percent, whereas Mexico's share fell slightly, from 11.3 percent to 10.9 percent. (Mexico's fall is partly due to its high share in 1990, as a result of high oil prices during the Gulf War.) Relative to 1992, China's share of the total in 1996 was about the same-that is, China's export growth rate was equal to the weighted average for the other six countries-while Mexico's share had increased. Of the Asian countries, Indonesia's and Korea's shares of total exports from the group fell, whereas the shares of Malaysia and the Philippines rose. Thailand's share rose from 9.6 percent in 1990 to 11.0 percent in 1994, and then fell slightly, to 10.2 percent in 1996 . On the whole, therefore, the Asian countries were not losing major market shares to China and Mexico.

The sharp real appreciation of the U.S. dollar relative to European 
Table 7. Export Growth and Export Shares, Selected Countries, 1990-96 ${ }^{\mathrm{a}}$

Percent

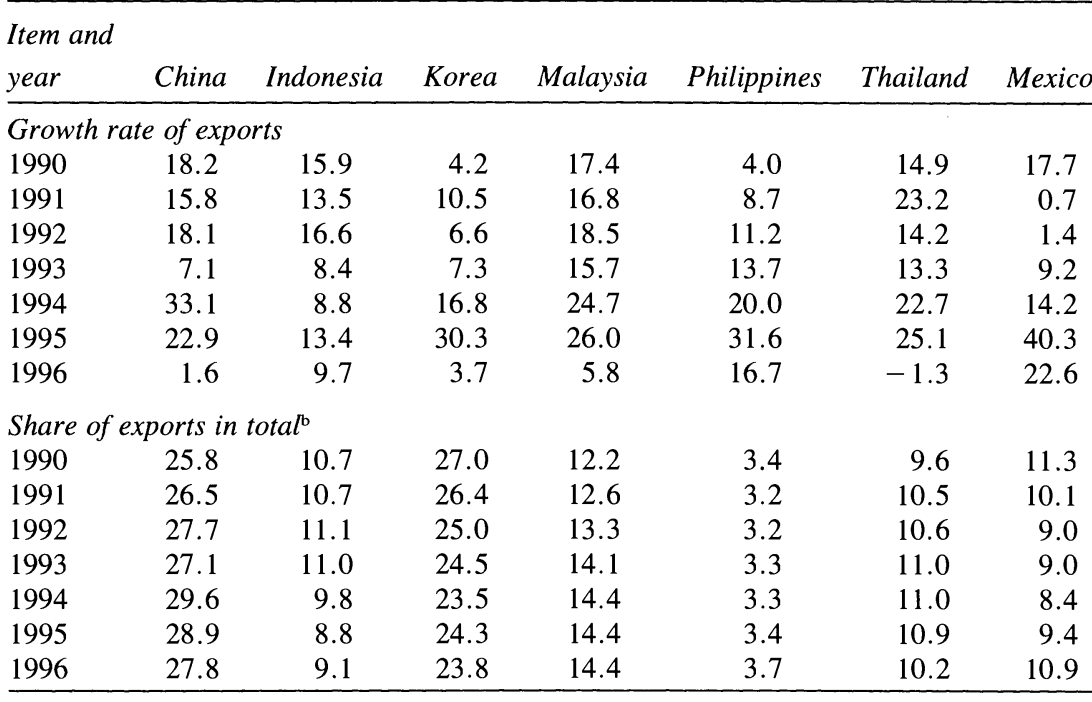

Source: IMF, International Financial Statistics, various issues.

a. Numbers refer to nominal exports valued in U.S. dollars.

b. Exports of a given country as a percentage of total exports from all seven countries.

currencies and the yen after 1994 also may have played some role in the Asian financial crisis. Since all of the Southeast Asian currencies were effectively pegged to the dollar, they appreciated significantly against the yen as the yen per dollar rate moved from $¥ / \$ 85$ in June 1995 to $¥ / \$ 127$ in April 1997. For example, each 100 yen of Thai exports to Japan brought in 29 baht in early 1995, but only 20 baht in early 1997. Prices of imports from Japan fell commensurably, providing some benefit to manufacturers that imported raw materials and intermediate goods from Japan. But since the unit values of both exports and imports fell for a wide variety of countries in 1996 (table 6), one can reasonably conclude that the appreciation of the dollar pushed down dollar prices on world markets for a wide variety of goods and services, including East Asian exports to Japan and Europe. Given that the bulk of East Asia's foreign debt is denominated in dollars, the appreciation of the dollar probably modestly increased the real debt servicing burden in these countries.

Each of the factors discussed above no doubt contributed to the export slowdown in 1996, which, in turn, probably raised concerns 
among creditors about the ability of Southeast Asian firms to repay their debts. But in the aggregate, the effect appears to have been modest. In contrast with the Latin American debt crises of the 1980s, it is difficult to attribute much weight to the contribution of international shocks to the East Asian financial crisis.

\section{Economic Management and Asian Capitalism}

The second major approach to explaining the East Asian crisis holds that it was brought on by weaknesses in Asian economic management. This type of hypothesis requires some amplification. As we have argued, there clearly were growing weaknesses in the Asian economies in the early 1990s, increasing their economic vulnerability. Haphazard and partial financial liberalization, coupled with pegged exchange rates, seem to have made the allocation of investment funds within these economies even worse. New banks and finance companies were allowed to operate without supervision or adequate capitalization. At issue is the extent to which these problems were responsible for the capital withdrawals, panic, and deep economic contraction that followed. Even if Asian "fundamental weaknesses" are fully to blame, one must still account for the fact that the crisis apparently was unanticipated; and, related, the continued high levels of capital inflow into East Asia up to the brink of the crisis.

One ingenious attempt to reconcile these factors within an overall critique of "Asian capitalism" is the argument put forward by Paul Krugman and Michael Dooley, that foreign investors expected that they would be bailed out as necessary. ${ }^{31}$ Assume that foreign creditors lent to Asian banks in the expectation that the central banks and the IMF would provide the Asian banks with funds to prevent their collapse in the event of a funding crisis. In that case, such foreign credits would be safe up to the amount of the expected bailout, which might (crudely) equal the foreign exchange reserves of a given central bank plus an anticipated sum from the IMF. Thus foreign creditors would have little need for due diligence on the repayment potential of the debtor financial institutions.

To examine this theory, one must check whether patterns of lending

31. Krugman (1998); Dooley (1997). McKinnon and Pill (1996) also use this framework. 
within the Asian economies did in fact deteriorate sharply in the 1990s (in view of the fact that investment allocations were quite successful in promoting growth and debt servicing in the 1970s and 1980s) and explore patterns of stock and land prices prior to the crisis. One should also look very closely at whether foreign investors operated on the expectation that they would receive bailouts as necessary, or rather, on the expectation of continued success in the Asian economies, and therefore little need for bailouts. Finally, one should examine whether this kind of theory helps to account for the closely related crises in Mexico and Argentina.

Table 8 shows shares of commercial bank and financial institution lending by sector for the five Asian crisis economies in 1990 and 1996. These data show some signs of a modest shift in lending away from manufacturing activities and toward construction, finance, real estate, and services. The extent of the shift differs across countries. In Indonesia the shift is fairly large, in Malaysia it is tiny, and in the Philippines it is moderate. In Korea and Thailand there is a very small shift in lending by the commercial banks, but a moderate shift for the other financial institutions. In aggregate, the data do indicate a modest shift in lending, but not a dramatic surge into real estate. These data probably do not accurately reflect loan composition, since a customer could claim that a loan will used to expand manufacturing capacity but actually use it to buy property or equity shares. Moreover, the shift in annual (new) net lending would be more pronounced than is indicated by this table, since these data are averages of all outstanding loans, including older loans.

One indicator of growing pressure in real estate markets is the price of property. If the crisis countries had indeed been in the midst of a speculative frenzy, one would expect to see real estate prices growing rapidly in the runup to the crisis, and then crashing. For example, Krugman argues that "in all of the afflicted countries there was a boom-bust cycle in the asset markets that preceded the currency crisis: stock and land prices soared, then plunged." ${ }^{32}$ However, the actual data (which he does not report), give at best mixed support to this hypothesis.

Table 9 shows stock and land prices indexes for both Thailand and Indonesia up to the crisis. In Thailand, stock prices rose very sharply

32. Krugman (1998, p. 2). 


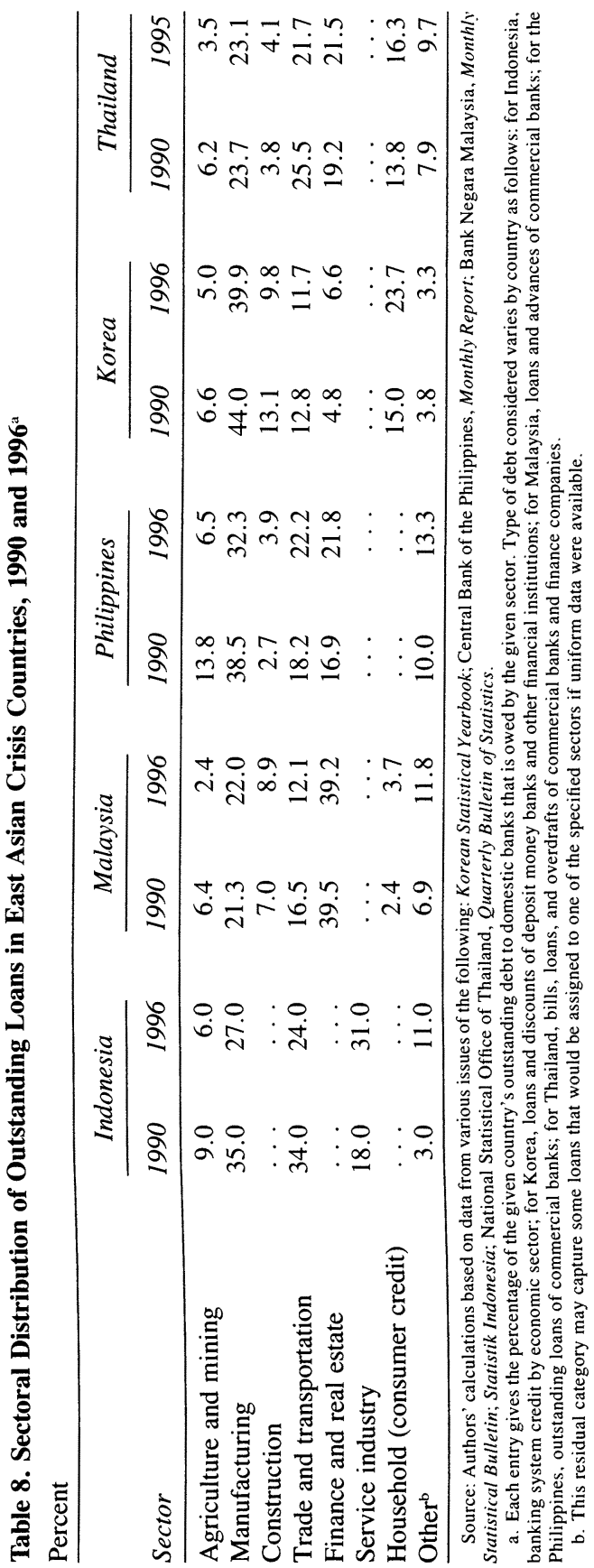


Table 9. Stock and Land Prices, Thailand and Indonesia, 1990-97

Units as indicated

\begin{tabular}{|c|c|c|c|c|}
\hline \multirow[b]{2}{*}{$\begin{array}{l}\text { Year and } \\
\text { quarter }\end{array}$} & \multicolumn{2}{|c|}{ Thailand } & \multicolumn{2}{|c|}{ Indonesia } \\
\hline & $\begin{array}{c}\text { Stock price } \\
\text { index }^{\mathrm{a}}\end{array}$ & Land price ${ }^{\mathrm{b}}$ & $\begin{array}{c}\text { Stock price } \\
\text { index }^{\mathrm{a}}\end{array}$ & Land price \\
\hline 1990:2 & 439 & 60.0 & 92 & 2,525 \\
\hline 1990:4 & 308 & 66.0 & 56 & 3,019 \\
\hline 1991:2 & 406 & 70.5 & 45 & 2,911 \\
\hline 1991:4 & 392 & 67.0 & 33 & 2,788 \\
\hline 1992:2 & 449 & 63.5 & 41 & 2,482 \\
\hline 1992:4 & 529 & 60.0 & 33 & 2,327 \\
\hline 1993:2 & 554 & 59.5 & 44 & 2,279 \\
\hline 1993:4 & 1,103 & 59.5 & 67 & 2,402 \\
\hline 1994:2 & 878 & 59.8 & 54 & 2,358 \\
\hline 1994:4 & 981 & 60.5 & 55 & 2,358 \\
\hline 1995:2 & 1,038 & 60.5 & 61 & 2,200 \\
\hline $1995: 4$ & 963 & 60.5 & 64 & 2,179 \\
\hline 1996:2 & 940 & 60.7 & 72 & 2,136 \\
\hline $1996: 4$ & 610 & 60.4 & 75 & 2,250 \\
\hline 1997:2 & 391 & 43.0 & 80 & 2,267 \\
\hline
\end{tabular}

Source: Data on stock prices are from Datastream's online service. Data on land prices are provided by Jones Lang Wooton.

a. Main index, in local currency.

b. Thousands of baht per square meter for "grade A" office space in Bangkok.

c. Dollars per square meter for "grade A" office space in Jakarta.

in the early 1990s, fell after 1995, and dropped sharply in the second half of 1996. Property prices (indicated by the sale prices of "grade A" office space in Bangkok, as rated by Jones Lang Wooton) showed almost no change between 1992 and the end of 1996, but fell sharply in early 1997, helping to set off the crisis. What is interesting is the apparent lack of increase in property prices between 1992 and 1996. There is even less evidence of a boom-bust pattern in Indonesia. Stock prices rose steadily by about 6 percent annually in real terms between 1992 and mid-1997, and did not decline until after the baht was floated. Land prices were almost exactly the same in June 1997 as they had been in June 1993, with no evidence of either a sharp rise or fall. The boom-bust cycle seems to have been a feature of the crisis in Thailandand perhaps, to a lesser degree, in Korea as well-but it was not so in Indonesia, which ultimately was the hardest hit. 
Table 10. Nonperforming Loans, Selected Crisis Countries, 1990-96a

Percent of total loans

\begin{tabular}{lrrrr}
\hline Country & 1990 & 1994 & 1995 & 1996 \\
\hline Indonesia & 4.5 & 12.0 & 10.4 & 8.8 \\
Korea & 2.1 & 1.0 & 0.9 & 0.8 \\
Malaysia & 20.4 & 8.1 & 5.5 & 3.9 \\
Thailand & 9.7 & 7.5 & 7.7 & $\ldots$ \\
Mexico & 2.3 & 10.5 & 14.4 & 12.5 \\
Argentina & 16.0 & 8.6 & 12.3 & 9.4 \\
\hline
\end{tabular}

Source: Bank for International Settlements (1997).

a. Equivalent data for the Philippines are not available.

Another possible indicator of loan quality is the share of nonperforming loans (NPLs) in total loans. Table 10 shows the share of NPLs for Indonesia, Korea, Malaysia, and Thailand, as well as Mexico and Argentina. As with the data on lending by sector, these data should be viewed with extreme caution. The numbers are undoubtedly lower bounds, since banks probably underreport NPLs. In any event, bad loans generally do not show up during periods of easy credit, but are only uncovered when credit conditions tighten. In fact, in each of the Asian countries in the table, reported NPLs fell during the years preceding the crisis. In Indonesia, the volume of NPLs peaked in 1993, two years after a dramatic monetary tightening put bank balance sheets under severe pressure. As banks began to be more profitable from 1994, many loans were written off. Indonesia's NPL ratio was also helped when Bank Dagang Negara, a large state-owned bank, cleaned up its balance sheet preparatory to listing its shares publicly. The World Bank, in a country report on Indonesia written in May 1997, just before the crisis, noted the decline in NPLs with caution but stated that the "quality of commercial bank portfolios continued to improve during 1996, albeit slowly.",33

In Malaysia, the dramatic drop in NPLs is probably due to the combination of a rapid increase in bank lending and a concerted effort to clean up balance sheets in the early 1990s. Nevertheless, it seems likely that loan quality deteriorated as lending expanded in the 1990s, especially in certain areas, such as real estate. And in Thailand, NPLs rose sharply for those financial institutions with heavy exposure to property

33. World Bank (1997, p. 128). 
Table 11. Incremental Capital-to-Output Ratios, Selected Countries, 1987-95 ${ }^{\text {a }}$

Ratio

\begin{tabular}{lccc}
\hline Country & $1987-89$ & $1990-92$ & $1993-95$ \\
\hline Indonesia & 4.0 & 3.9 & 4.4 \\
Korea & 3.5 & 5.1 & 5.1 \\
Malaysia & 3.6 & 4.4 & 5.0 \\
Philippines & 3.3 & 22.8 & 6.0 \\
Thailand & 2.9 & 4.6 & 5.2 \\
Chile & 2.9 & 3.3 & 4.4 \\
Colombia & 4.3 & 4.7 & 4.1 \\
India & 3.2 & 6.0 & 4.7 \\
Mexico & 8.9 & 6.5 & 11.7 \\
Pakistan & 2.8 & 2.9 & 4.9 \\
Turkey & 6.8 & 5.4 & 9.2 \\
\hline
\end{tabular}

Source: Authors' calculations based on data from World Bank, World Development Indicators, available on CD-ROM. a. Ratio calculated as investment over a given three-year period divided by the change in real GDP during the same period, $\left[\left(I_{t}+I_{t+1}+I_{t+2}\right) /\left(Y_{t+2}-Y_{t-1}\right)\right]$.

markets when Bangkok property prices fell in early 1997, and the costs of those bad debts mounted rapidly in early 1997 . However, a dramatic deterioration in loan quality during the early 1990s throughout the region, as some have suggested, does not show up in the data.

A crude macroeconomic indicator of the quality of investment is the incremental capital-to-output ratio (ICOR) - that is, the ratio of the value of new investment to the change in output in a given year. Table 11 shows ICORs for selected emerging markets over the period 1987-96. This measure has to be viewed with some caution, since it does not provide for necessary lags between investment and changes in output. Generally speaking, when investment quality deteriorates, the ICOR increases, as more investment spending is needed to support a given increase in GDP. Investment rates rose in the five Asian crisis economies in the early 1990s, as the increased capital inflows added to already high saving to create a large pool of investment funds. Economic growth continued to be brisk, but did not rise commensurably with the increase in investment. As can be seen from table 11, ICORs accordingly rose in every country in the region except the Philippines, where economic growth was very slow through 1992 . These data can be interpreted to suggest either a decline in investment quality, diminishing returns to new investment during the process of capital deepening, or a lag between the heavy investment spending in the 1990s and an increase in growth. However, similar increases in the ICOR are 
recorded for emerging markets that did not experience crises, such as Chile, and much larger increases are recorded for Turkey and Mexico, which experienced crises in 1994 and 1995, respectively.

How can one reconcile these data with the popular perceptions that banks were lending recklessly, especially for real estate, in East Asia, and that investment quality had sharply deteriorated during the early 1990s? We believe that it is a matter of degree. While we have shown that bank lending was increasing rapidly, and lending activities almost certainly exceeded prudential limits in some cases, it is much too easy in hindsight to overstate the extent of bad loans. Clearly there were many profitable ongoing investments in manufacturing activities that were earning a solid rate of return. A substantial share of lending supported labor-intensive manufactured exports, which one does not normally associate with irrational boom-bust cycles or gambling.

Did foreign lenders believe that Asia's financial situation was unsustainable, but continue to lend in the expectation of an eventual bailout? It is hard to find any generalized perception of an impending major problem, either in the available data or in statements and reports made before the crisis. If lenders had perceived a growing risk, for example, spreads on Asian bonds should have increased. However, William Cline and Kevin Barnes show that spreads of both bonds and syndicated loans actually fell in emerging markets, including Southeast Asia, between mid-1995 and mid-1997, and the Bank for International Settlements also reports declining spreads. ${ }^{34}$ Following the Mexican crisis, it was widely believed in Asia that a similar crisis could not happen there.

Alternatively, if international markets perceived growing risks of a crisis and bailout in Asia, ratings of long-term government bonds by Moody's, Standard and Poor's, and Euromoney would have declined. In fact, these ratings were either stable or improving in each of the five Asian crisis economies between 1995 and 1997, and did not fall until after the onset of the crisis. Even in Thailand, where private investors began to be concerned in late 1996 and early 1997 when property prices fell, sovereign bond ratings remained high right up to the float of the baht. Indeed, contemporary reports and newsletters of investment banking firms gave a nuanced picture. They often pointed out weaknesses in the Asian economies (for example, slower export growth, rapid loan 
growth, booming property markets), but did not give any sense of a bubble waiting to burst. Most investment analysts displayed guarded confidence in the prospects of Southeast Asia, in both the short and the long runs.

As to whether investors expected to be bailed out if there were a crisis, there is no question that many banks and firms across Asia had close government connections that supported their profitability. Stateowned banks obviously could expect to be bailed out if there were a crisis. In Korea, none of the chaebol had been allowed to fail for a decade before Hanbo steel collapsed in early 1997. In Indonesia, firms closely connected with the first family or the armed forces have long been given special privileges. And across Asia, infrastructure projects under build-own-operate or build-own-transfer relationships, such as electric utilities, are generally guaranteed a revenue stream from government agencies.

It is hard to make the case, however, that foreign investors felt themselves in a general way to be indemnified against risk through the prospect of generous bailouts. A substantial share of funds went to equity markets, where price fluctuations were indeed risky. Even bank loans were heavily concentrated in the nonfinancial corporate sector, often with little prospect of a direct government bailout. Moreover, creditors have long complained that weak bankruptcy laws and ineffectual judicial systems in Asian countries reduce their ability to collect on collateral in the event of nonperforming loans - that is, they worry that they will not be compensated if loans go bad. Thus it is probably fairer to say that foreign investors thought too little about risk because they expected rapid growth and high profitability to continue, rather than because they expected a bailout.

To summarize, the combination of rapid inflows of foreign capital, appreciating real exchange rates, and rapid growth in bank lending undoubtedly led to some deterioration in the quality of investments in Asia. Lenders to some well-connected firms and to major commercial banks no doubt felt secure in their positions, confident that they would make a good profit and that the odds of default were slim. Some-but relatively few-observers saw a major financial crisis on the horizon. Speculators certainly did not smell a kill in Asia in the aftermath of the Mexican peso crisis. There was almost no expectation of a widespread financial crash and a subsequent bailout. 


\section{Financial Market Instability}

The third approach to explaining the East Asian crisis holds that it was triggered by dramatic swings in creditors' expectations about the behavior of other creditors, thereby creating a self-fulfilling - although possibly individually rational-financial panic. This hypothesis depends on several underlying assumptions: (1) that fundamental conditions, though not perfect, were strong enough to sustain reliable debt servicing; (2) that needed adjustments in exchange rates could have been carried out in mid-1997 without financial collapse; and (3) that foreign exchange and financial markets in fact overshot in their initial reactions to the panic at the end of 1997 . It is consistent with several major facts: the role of short-term debt in the onset of the crisis, the unexpected nature of the crisis, the continued rapid lending to Asia until the brink of the crisis, and the initial overshooting, as indicated by the reversal of exchange rate and stock indexes from January 1998. We have elaborated the theory underlying this view at some length. We now show that it is the most successful at accounting for which emerging markets have succumbed to financial crises in recent years.

To test the relative strength of alternative risk indicators in predicting the onset of a financial crisis in the emerging markets during the period 1994-97, we estimate a simple probit model in which the onset of a financial crisis depends on a vector of economic and institutional variables, including the variables suggested in the discussion above. We use a panel of data for the years 1994-97 for twenty-two emerging markets. Our left-hand-side variable is a $0-1$ indicator, equal to 1 if the country fell into a financial crisis during the year and to 0 otherwise. For these purposes, we define financial crisis as a sharp shift from capital inflow to capital outflow from year $t-1$ to year $t$. Nine cases are set equal to 1: Turkey and Venezuela in 1994; Argentina and Mexico in 1995; and Indonesia, Korea, Malaysia, the Philippines, and Thailand in 1997. Note that after a crisis has occurred, we drop the subsequent observations of the country (since we suppose that a true reversal from inflow to outflow can occur only once in the interval). Thus we do not include observations for Turkey and Venezuela over 1995-97, or observations for Argentina and Mexico over 1996-97. In total, we have seventy-eight observations ( $22 \times 4-10$ excluded observations).

According to the central hypothesis of financial market instability, 
one would predict that countries with a high ratio of short-term debt to short-term assets (measured as the ratio of short-term debt, reported by the Bank for International Settlements, to the foreign exchange reserves of the central bank) would be more vulnerable to crisis. A high ratio of short-term debt to reserves will not necessarily induce a crisis in a given year, but it is likely to make foreign creditors realize that there is not enough foreign exchange available to pay off all short-term creditors in the case of a panic. Alternatively, if one believes that the crisis is a matter of fundamental solvency, one might expect that total debt outstanding, regardless of its maturity, would matter more than short-term debt. Therefore we include as a second possible explanatory variable the ratio of total foreign debt to reserves.

Our discussion also suggests that countries with a rapid build-up in bank credit would have more fragile banking systems, a greater quantity of bad loans, and therefore greater vulnerability to a crisis. Specifically, we measure the ratio of the claims of the financial sector on the private sector relative to GDP, and then calculate the change in that ratio over the preceding three years. Countries with sharply rising financial sector claims relative to GDP are expected to be more vulnerable to financial crisis. As an alternative measure (available for only a subset of the sample), we use an index of bank strength based on 1996 ratings of commercial banks in each country by Moody's Investors Service, as reported by Barry Bosworth. ${ }^{35}$

In addition, since some observers claim that large current account deficits lead to crisis, we test the explanatory power of the ratio of the current account to GDP. The current account, per se, may not be as important as the capital account, given our focus on capital inflows as a key component of the crisis. In each episode, the capital account surplus was even larger than the current account deficit. Therefore we also examine the ratio of the capital account to GDP.

We also examine several other variables. For example, real exchange rate appreciation could signal a crisis. We therefore test the explanatory power of an index of the percentage change in the real exchange rate in the previous three years. A rise in the real exchange rate indicates a real depreciation. Further, in the aftermath of the Asian crisis, many observers have decried widespread corruption and crony capitalism as

35. Bosworth (1998). We are grateful to Barry Bosworth for supplying these data. 
Table 12. Probit Results Predicting the Onset of Financial Crises ${ }^{\mathrm{a}}$

\begin{tabular}{lcccc}
\hline Independent variable & $(12-1)$ & $(12-2)$ & $(12-3)$ & $(12-4)$ \\
\hline Current year & & & & \\
Short-term foreign debt/reserves & 0.57 & 0.65 & 0.75 & 2.41 \\
& $(2.50) \dagger$ & $(2.41)^{\dagger}$ & $(2.36) \dagger$ & $(2.11) \dagger$ \\
Total foreign debt/reserves & & & & -0.99 \\
& & & & $(-1.49)$ \\
Freedom from corruption ${ }^{\mathrm{b}}$ & & -0.36 & -0.39 & -0.36 \\
& & $(-1.14)$ & $(-1.24)$ & $(-1.04)$ \\
Lagged one year & 3.22 & 2.48 & 3.46 & 4.05 \\
Private credit buildup & & $(2.34) \dagger$ & $(1.87)^{*}$ & $(2.38) \dagger$ \\
& $(2.31)^{\dagger}$ & 4.03 & & 2.69 \\
Capital inflow/GDP & $(1.85)^{*}$ & $(2.09) \dagger$ & & $(0.97)$ \\
& & & -14.63 & \\
Current account surplus/GDP & & & $(-1.55)$ & \\
& & -0.00 & -0.00 & -0.01 \\
Real exchange rate change ${ }^{\mathrm{d}}$ & & $(-0.26)$ & $(-0.14)$ & $(-0.59)$ \\
& & -1.42 & -1.73 & 1.56 \\
Constant & $(-4.91) \dagger$ & $(-1.20)$ & $(-1.38)$ & $(-1.17)$ \\
& & & & \\
Summary statistic & 0.24 & 0.28 & 0.33 & 0.37 \\
Pseudo $R^{2}$ & 78 & 78 & 78 & 78 \\
\hline
\end{tabular}

Source: Authors' regressions. Data on short-term debt are from Bank for International Settlements (1998); on total debt, from World Bank, World Development Indicators, available on CD-ROM; on reserves, private credit, GDP, exchange rates, and capital inflow, from IMF, International Financial Statistics, various issues; and on corruption, from Political Risk Services (various issues).

a. Dependent variable is a dummy, set equal to 1 for a given country in year $t$ if that country experiences a sharp switch from capital inflow (in year $t-1$ ) to capital outflow (in year $t$ ). The panel comprises the twenty-two emerging markets listed in table 14 over 1994-97; but once a country experiences a crisis, it is excluded from the panel in all subsequent years. $z$ statistics are in parentheses. Significance at the 10 percent level is denoted by *; at the 5 percent level, by $\dagger$.

b. Index of corruption ranges from 1 to 6 , where a lower score indicates greater corruption.

c. Three-year change ( $t-4$ to $t-1)$ in the ratio of financial system claims on the private sector to GDP.

d. Three-year percent change ( $t-4$ to $t-1)$. An increase represents a depreciation. For details of calculation, see table 2, note $\mathrm{c}$.

an underlying cause. To test this idea, we include a cross-country comparative index of corruption, as judged by a leading political risk advisory service. The corruption index is measured on a scale from 1 to 6 , with 1 indicating the most corruption.

Regression results are shown in table 12. As expected, a higher ratio of short-term debt to reserves is strongly associated with the onset of a crisis. The estimated coefficient is positive and significant at the 5 percent level in each specification. Table 13, which gives the means of 
Table 13. Means and Standard Deviations of Variables Used in Probit Regressions ${ }^{a}$ Units as indicated

Subsample

\begin{tabular}{|c|c|c|}
\hline \multirow[b]{2}{*}{ Variable } & \multicolumn{2}{|c|}{ Subsample } \\
\hline & Crisis observations & Noncrisis observations \\
\hline \multicolumn{3}{|l|}{ Current year } \\
\hline Short-term foreign debt/reserves & $\begin{array}{c}1.82 \\
(1.40)\end{array}$ & $\begin{array}{c}0.99 \\
(1.01)\end{array}$ \\
\hline Total foreign debt/reserves & $\begin{array}{c}2.31 \\
(0.78)\end{array}$ & $\begin{array}{c}2.17 \\
(3.06)\end{array}$ \\
\hline Freedom from corruption ${ }^{\mathrm{b}}$ & $\begin{array}{c}3.22 \\
(0.67)\end{array}$ & $\begin{array}{c}3.60 \\
(0.91)\end{array}$ \\
\hline \multicolumn{3}{|l|}{ Lagged one year } \\
\hline Private credit buildup ${ }^{c}$ & $\begin{array}{c}0.17 \\
(0.21)\end{array}$ & $\begin{array}{c}0.04 \\
(0.20)\end{array}$ \\
\hline Capital inflow/GDP & $\begin{array}{c}0.07 \\
(0.02)\end{array}$ & $\begin{array}{c}0.03 \\
(0.18)\end{array}$ \\
\hline Current account surplus/GDP & $\begin{array}{r}-0.05 \\
(0.02)\end{array}$ & $\begin{array}{r}-0.02 \\
(0.07)\end{array}$ \\
\hline Real exchange rate changed & $\begin{array}{r}-15.82 \\
(8.42)\end{array}$ & $\begin{array}{c}-15.92 \\
(27.21)\end{array}$ \\
\hline
\end{tabular}

Source: see table 12 .

a. Panel of country years is partioned according to whether the crisis dummy is equal to 0 or 1 ; for details, see table 12 , note a. Standard deviations are in parentheses.

b. Index of corruption ranges from 1 to 6 , where a lower score indicates greater corruption.

c. Three-year change $(t-4$ to $t-1)$ in the ratio of financial system claims on the private sector to GDP

d. Three-year percent change $(t-4$ to $t-1)$. An increase represents a depreciation. For details of calculation, see table 2 , note $\mathrm{c}$.

the regressors, shows that the debt-to-reserves ratio averages 1.82 in the nine crisis episodes and 0.99 in the noncrisis episodes. Table 14 gives the values of the regressors by country. Note that in eight of the nine crisis episodes, the ratio of debt to reserves exceeded 0.8 (the only exception is Malaysia, with a ratio of 0.61 ). This value is exceeded by only three of the thirteen noncrisis economies: Russia, South Africa, and Zimbabwe. It is possible to have a high level of short-term debt without entering a crisis-the Asian countries generally escaped contagion from Mexico in 1995-but it does seem to indicate vulnerability to a crisis.

The ratio of total debt to reserves, by contrast, is not statistically associated with a crisis (equation 12-4); this result holds up even when the short-term debt variable is excluded. The average ratio of total debt 


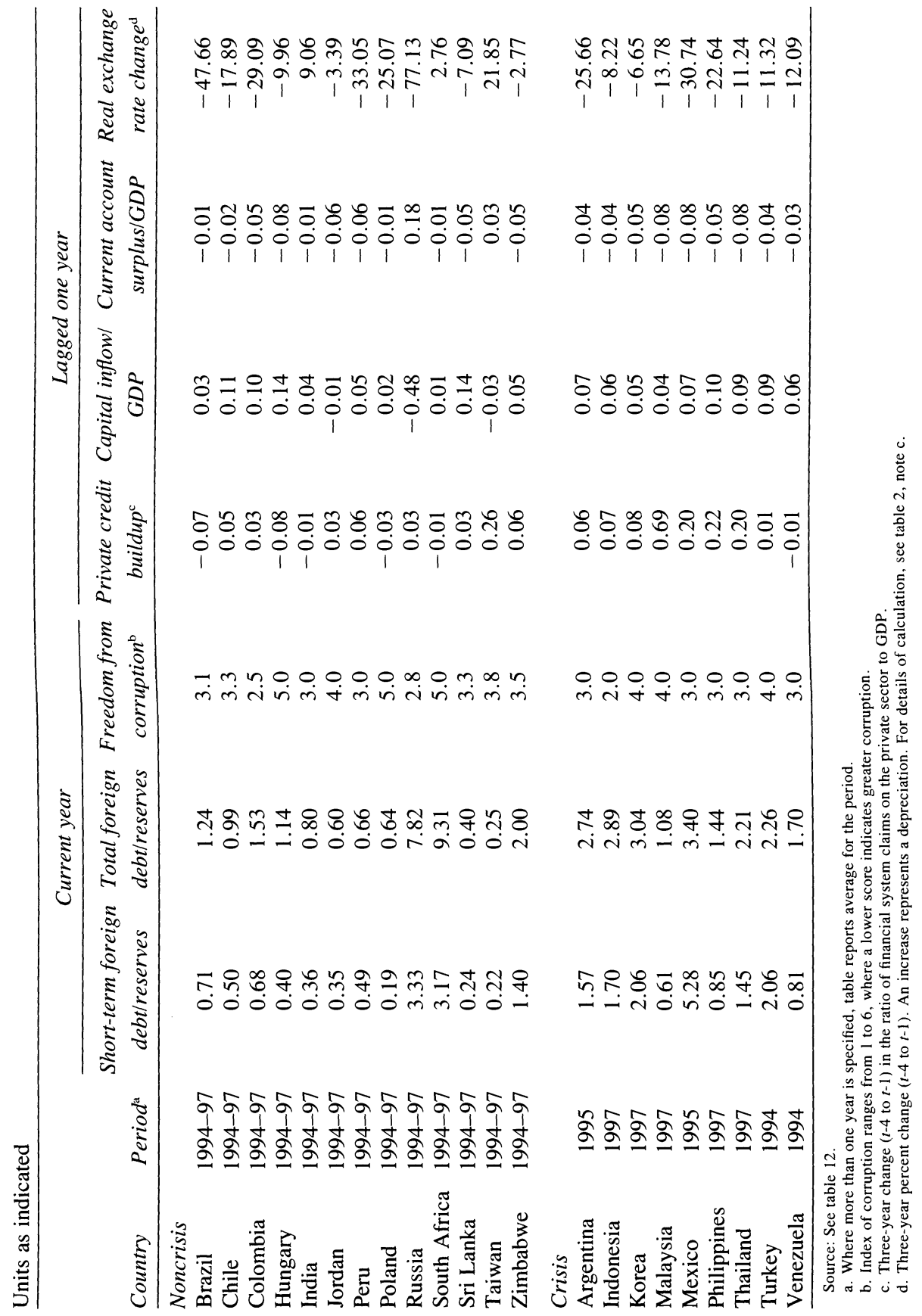


to reserves is slightly larger in the crisis countries (2.3) than in the noncrisis countries (2.2), but the difference is small. This evidence strongly suggests that these are indeed crises of liquidity, not solvency.

A rapid buildup in the claims of the financial sector on the private sector is also associated with crises. The estimated coefficient is positive and significant at the 5 percent level in three of the four specifications. The ratio of claims to GDP increased by 17 percentage points in the crisis economies in the three years prior to the observation, but by only 4 percentage points in the noncrisis countries. Thus there is some evidence to support the notion that it is the buildup of bank claims that leaves the financial system weakened and vulnerable to attack. Nevertheless, one should remember that in Mexico in 1994 and in Indonesia in 1997, the short-term debt problems lay mostly outside the banking systems: with the government in the former case, and with the nonfinancial corporate sector in the latter.

A larger current account deficit is only weakly associated with the onset of a crisis. In equation 12-3, the estimated coefficient on the current account is of the correct sign but is insignificant at the 10 percent level. As can be seen from table 13, current account deficits averaged 5 percent of GDP in the crisis episodes, compared with 2 percent in the noncrisis episodes. But the stronger relationship between crises and the capital account ratio is shown in equations 12-1, 12-2, and 12-4. This seems reasonable, since the pressures are created by capital inflows, rather than the trade and current account deficits per se. However, the relationship is not as strong as with short-term debt or the increase in banking sector claims.

Somewhat surprisingly, our measure of real exchange rate overvaluation does not seem to be associated with financial crisis. In each specification, the estimated coefficient on the change in the real exchange rate is close to zero and is insignificant. There is almost no difference in the average change in the real exchange rate in the previous three years between the crisis $(-15.8$ percent $)$ and noncrisis ( -15.9 percent) episodes. Finally, the level of corruption is not significantly associated with financial crises, even after controlling for the level of short-term debt, bank credit, and other variables. While the estimated coefficient is of the correct sign, it is not significant at conventional levels. There is little difference in the level of perceived corruption in the crisis and noncrisis economies: the corruption indexes 
average 3.2 and 3.6, respectively. To put it another way, there is extensive corruption in East Asia, but so too in other emerging markets that did not fall prey to financial crisis; corruption does not seem to have been the driving force of the East Asian crisis.

Our simple probit technique is obviously limited. The variables are no doubt measured with significant error. Not all emerging markets crises can be lumped into a single model. And yet, the cross-country evidence is highly suggestive: the defining element of such crises has been the vulnerability to panic, as measured by high ratios of shortterm debt to reserves. A rapid buildup of bank claims is also predictive. Measures of foreign borrowing per se-whether the total stock of debt or the flow current account deficit-are less important. Corruption is rife in emerging markets, but corruption does not necessarily signal the demise of an economy.

\section{The IMF Response to the East Asian Crisis}

The official international response to the East Asian financial crisis, led primarily by the IMF, has evolved over time. A dividing line was reached at the end of December 1997, when the mechanisms and goals originally envisioned by the IMF were altered in view of rapid change in market outcomes. Thus our analysis distinguishes two phases in crisis management: August 1997 to December 24, 1997, and December 24, 1997 to the present (April 1998).

\section{Phase One}

The International Monetary Fund signed three emergency lending agreements with Thailand in August 1997, Indonesia in November 1997, and Korea in December 1997. These three programs established an unprecedented sum of international financial support: $\$ 17$ billion for Thailand, \$35 billion for Indonesia, and \$57 billion for Korea. The financing commitments under these agreements are detailed in table $15 .{ }^{36}$ However, these figures overstate the amount of funding that was actually made available. In both Indonesian and Korean packages, \$22

36. Note that although the Indonesian program was officially counted as $\$ 40$ billion, $\$ 5$ billion of this sum represented Indonesia's own money. 


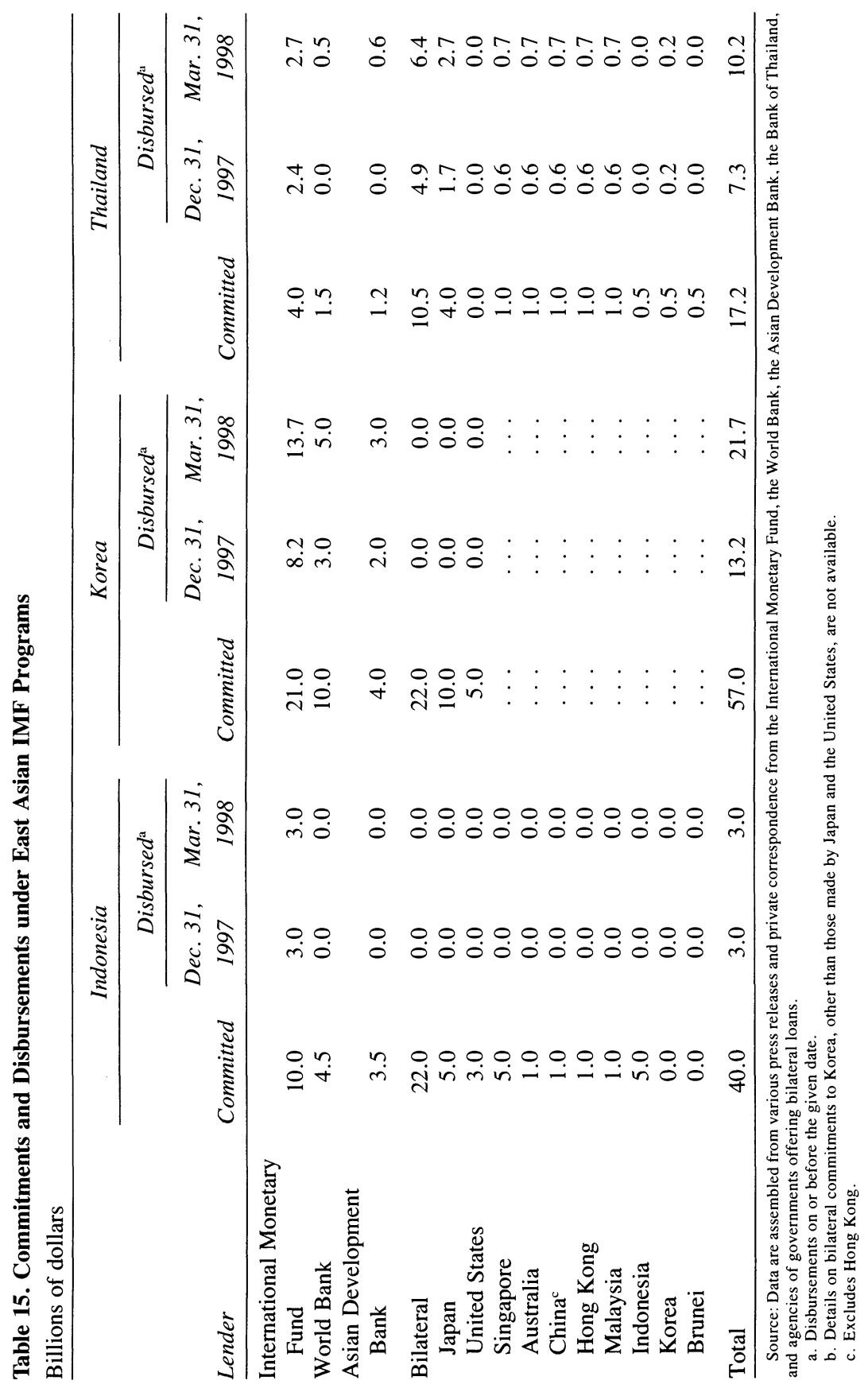


billion were "second line of defense" funds from individual donor governments (mainly the United States, Japan, Singapore, and the Europe countries), with relatively little likelihood of being available early in the program. The rest of the money was to be disbursed over a threeyear period, according to a preestablished schedule, so that only some of these funds could be made available early in the adjustment program.

The three loan agreements were similar in basic design. Each involved the following elements:

- a package of loans to the central bank and government that could be drawn on, directly or indirectly, to support the repayment of debts falling due to international creditors and to stabilize exchange rates;

- a macroeconomic framework based on budget balance or surplus, and high nominal interest rates and restrictive domestic credit targeted at exchange rate stability;

- a program of drastic financial sector restructuring, based on immediate closure or suspension of several financial institutions and significant intensification of financial sector supervision in various forms; -other "good governance" and "structural" measures aimed at increasing the transparency and competitiveness of the economic system, including accelerated trade reform, demonopolization, and privatization.

The IMF's immediate objective was to reestablish financial market confidence, in particular, by stabilizing the exchange rate. Exchange rate stabilization was to be based on a combination of macroeconomic discipline (fiscal balance, high interest rates, tight credit), increased availability of foreign exchange reserves, and confidence that fundamental economic reforms were moving forward. Such reforms would be signaled by decisive actions at the start of the program to close or suspend loss-making financial institutions, as well as the announcement of a strict timetable of longer term measures regarding financial markets, corporate governance, and increased market competition in various areas.

The mechanics of the IMF loans merit special attention. The three packages differed somewhat, both in the letter and in the application of the agreements. As noted above, in all cases, the loan packages had the direct function of providing the central bank with reserves to support the repayment of debts falling due, while limiting the adverse effects of such repayments on the exchange rate. In the case of Korea, the 
linkage between the loan package and the repayment of foreign debts was direct and fairly automatic. In early December the commercial banks simply notified the Bank of Korea of the daily foreign creditor demands for foreign exchange loan repayments. The Bank of Korea then credited these banks with the necessary foreign exchange. In this way, the foreign creditors were repaid out of the IMF loan package; the Bank of Korea became the creditor of the Korean commercial banks and the debtor of the IMF. The upside of this arrangement was that the original loans were repaid and default was avoided. The downside was that the original private loans were in effect socialized. If the original loans had been allowed to default, the foreign creditors and the owners of the Korean banks would have shared the bulk of the losses. ${ }^{37}$ Instead, the foreign creditors were allowed to escape and the Korean government took over the burden of repaying the foreign debts-now owed to the IMF.

Thailand presents a case similar to Korea. The central bank made credits available to financial institutions to support the repayment of foreign debts. Moreover, in January 1998 the government made explicit its guarantees on all bank liabilities, including debts owed to foreign creditors, thereby effectively pledging foreign exchange reserves to the servicing of bank debts.

In Indonesia, by contrast, most of the short-term debts were owed by nonfinancial corporations, which were not entitled to direct credit lines from Bank Indonesia. The IMF loans therefore could only support repayments indirectly, by allowing Bank Indonesia to intervene in the foreign exchange market to provide dollars at a cheaper rate than would otherwise have been available, thus reducing the rupiah cost of servicing the debts.

The IMF has emphasized that the lending packages were intended to support stabilization, not merely to bail out foreign financial institutions. It hoped that its role as a quasi lender of last resort would sufficiently restore market confidence that the Asian governments would not need to draw down the full package of loans. If exchange rates could be stabilized and default avoided, the thinking presumably ran, private lending would revive. In addition, the IMF clearly feared that outright default in Asia would trigger a massive upheaval in other emerging

37. The Korean government might still have borne some of the losses if the Korean banks had become fully insolvent, since the repayment of the domestic deposits in the insolvent banks would probably have required public rescue funds. 
Figure 4. Korea: Policy Events and the Exchange Rate, July 1997 to March $1998^{\text {a }}$

Won per dollar

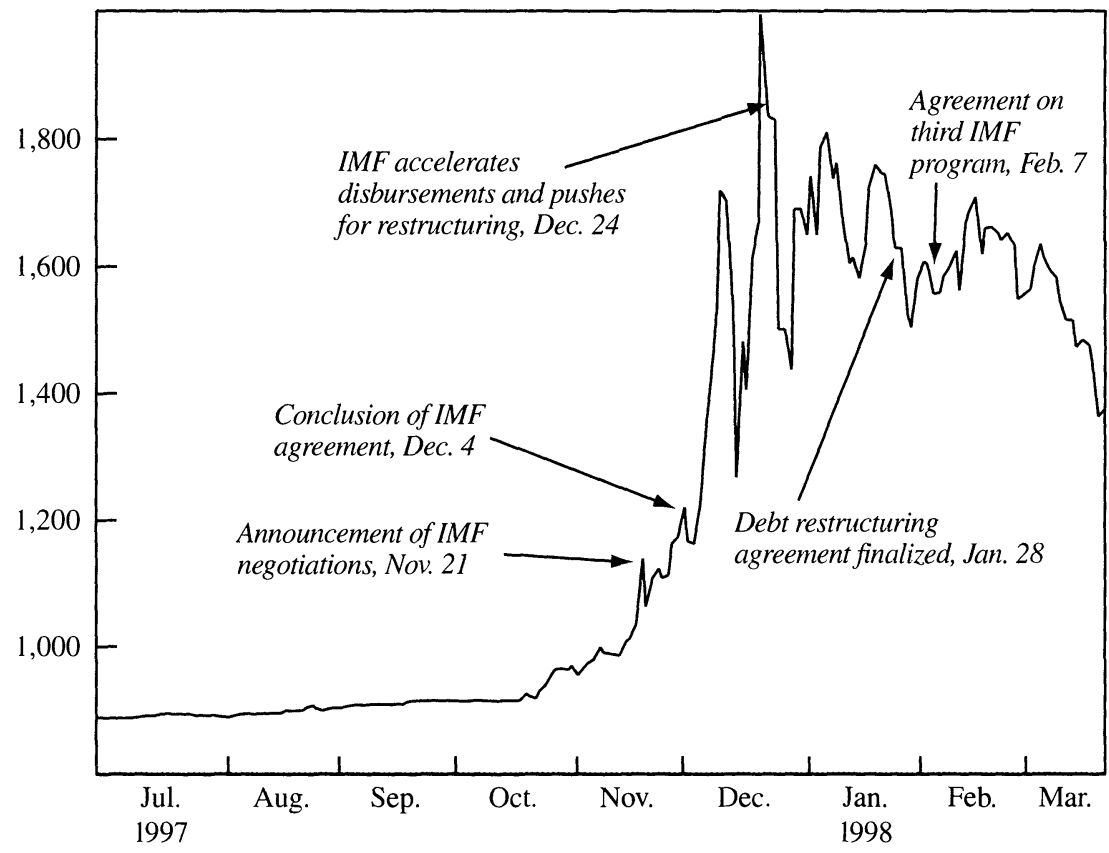

Source: Data through November 30, 1997 are from Datastream's online service; subsequent data are from the worldwide web page of Bloomberg.

a. Data are daily, June 30, 1997 through March 23, 1998, and tic marks correspond to the first day of the given month.

markets. Therefore, even if the loan packages did little more than repay creditors and forestall default in Asia, they might have important salutary effects in other emerging markets.

During the period August 1997 to December 1997, the IMF programs failed dramatically to restore market confidence. Figures 4 to 9 show the movements of exchange rates and stock markets in Indonesia, Korea, and Thailand in the aftermath of the IMF agreements. In all three countries, the exchange rate was expected to stabilize but in fact quickly depreciated far below the targets set in the program, despite a very sharp increase in interest rates. Foreign investors remained unconvinced about the debt servicing capacity of the private debtors and continued to demand the repayment of short-term loans as they fell due. Official reserves fell more rapidly than the IMF had predicted. In the case of Korea, the withdrawal of short-term debts was so much more intense 
Figure 5. Thailand: Policy Events and the Exchange Rate, July 1997 to March $1998^{a}$

Baht per dollar

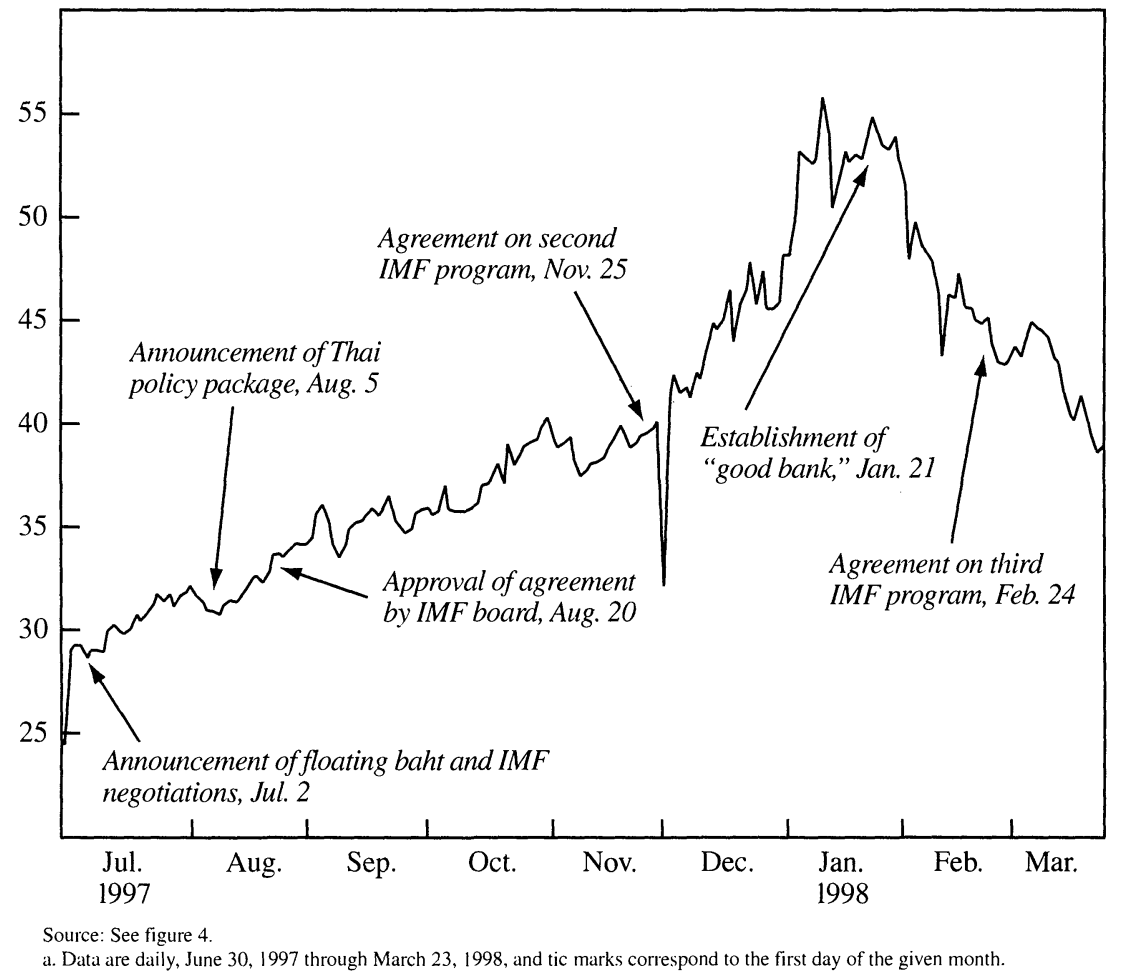

than allowed for in the program implemented on December 3 that the country faced imminent default by December 24. Indeed, on December 22 Moody's downgraded the sovereign debts of all three countries to junk bond status.

The basic goals of IMF programs, enunciated in article 1 of its Articles of Agreement, include "to give confidence to members by making the general resources of the Fund temporarily available to them under adequate safeguards, thus providing them with opportunity to correct maladjustments in their balance of payments without resorting to measures destructive of national or international prosperity." The most important measure of the failure of the IMF programs in East Asia thus lies in the outcomes on economic growth shown in table 16. Since the launch of these programs, actual outcomes in each country have been far worse than projected. The IMF has repeatedly been forced to 
Figure 6. Indonesia: Policy Events and the Exchange Rate, July 1997 to March $1998^{\text {a }}$

Rupiah per dollar

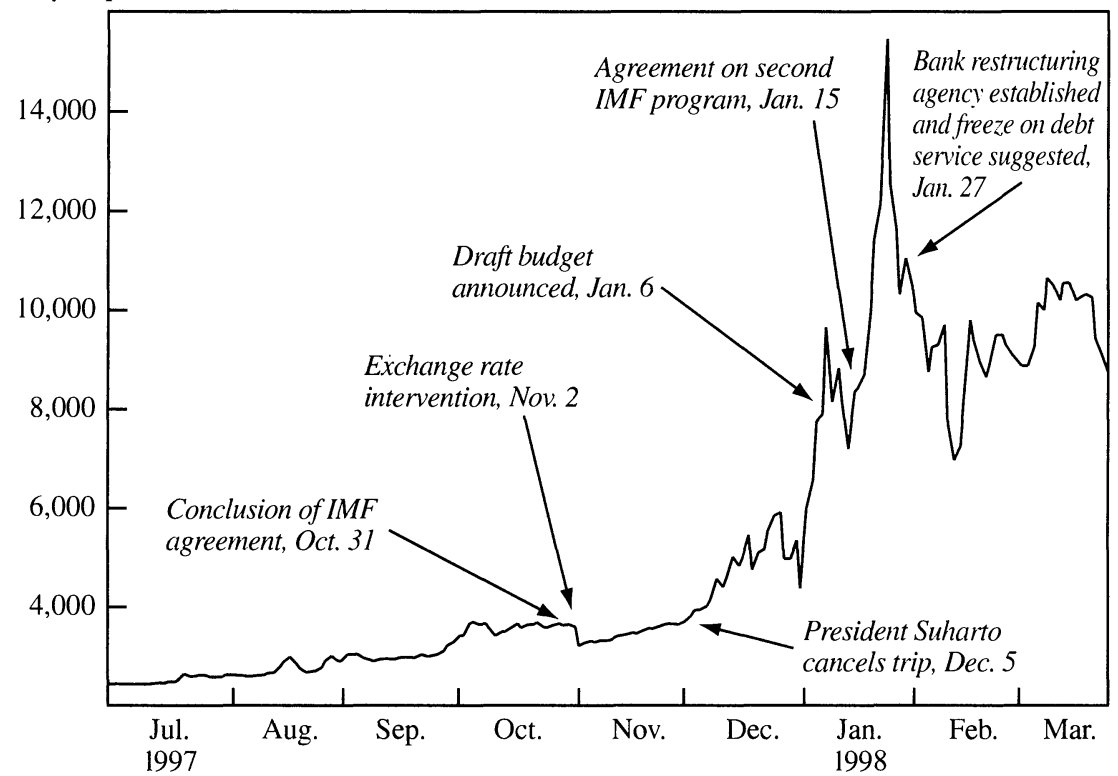

Source: See figure 4.

a. Data are daily, June 30, 1997 through March 23, 1998, and tic marks correspond to the first day of the given month.

reduce its growth forecasts for 1998. And the much lower revised forecasts are still much more optimistic than those of private forecasters. When pressed on this point, IMF officials answer that their original forecasts were built on best case assumptions. But there is much more to it than that: as discussed below, the IMF's own responses added to the risks of a sharply contractionary outcome.

\section{Phase Two}

The management of the East Asian financial crisis entered a new phase on December 24, 1997. With Korea on the brink of default, the U.S. government (led by the Federal Reserve Board and the U.S. Treasury) decided to press foreign commercial banks to roll over their shortterm credits to that country on an enforced basis, rather than waiting for market confidence to be restored. The banks and the Korean government initially announced a standstill on debt servicing, pending a formal agreement. On January 16, 1998, they agreed to a complete rollover of all short-term debts falling due in the first quarter of 1998. 
Figure 7. Korea: Policy Events and Stock Prices, July 1997 to March $1998^{a}$

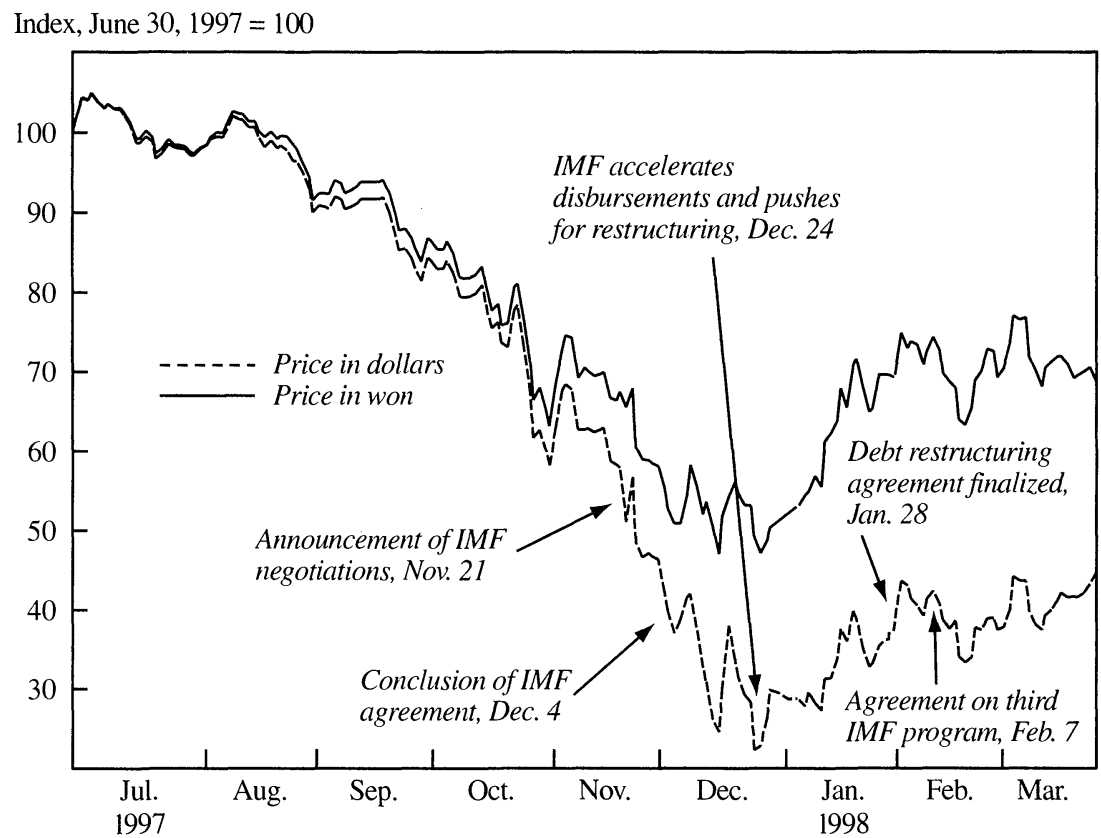

Source: Data through November 30, 1997 are from Datastream's online service: subsequent data are from the worldwide web page of Yahoo.

a. Data are daily. June 30, 1997 through March 23, 1998, and tic marks correspond to the first day of the given month.

On January 28, an agreement was reached to convert $\$ 24$ billion in short-term debt to claims with maturities of between one and three years. The IMF, with the backing of the United States, insisted on the comprehensive debt rollover as a condition for further disbursements under the IMF lending package-in fact, those disbursements were accelerated as part of the new arrangement. In one sense, the new arrangement represented the failure of the conception embodied in the original loan programs for the Asian crisis economies. Rather than using a loan package in combination with economic reforms to restore market confidence, the new arrangement meant a nonmarket postponement of debts falling due, albeit ratified by market participants in a collective undertaking.

The new arrangements put a brake on the fall of the Korean won, and also on the decline in stock markets of all three crisis countries. The currencies of Thailand and Indonesia, however, continued to depreciate for several more weeks. The depreciation of the Thai baht 
Figure 8. Thailand: Policy Events and Stock Prices, July 1997 to March $1998^{a}$

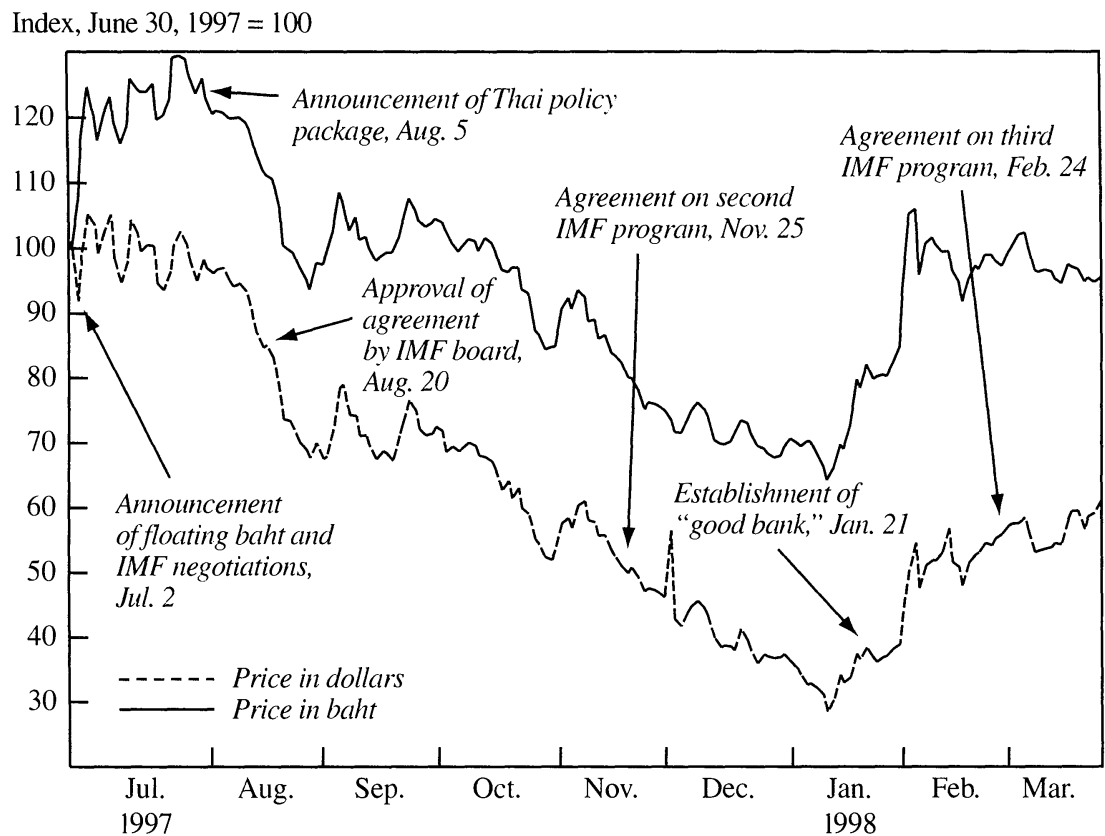

Source: See figure 7.

a. Data are daily, June 30, 1997 through March 23, 1998, and tic marks correspond to the first day of the given month.

seems to have ended around January 21, 1998, when the government formalized its guarantee of all liabilities owed by Thai commercial banks, including those to foreign creditors. The clarification of such state guarantees on what had been private sector debts, in combination with other policy actions and the improvements in Korea, initiated a period of currency appreciation. In the meantime, Thai corporate debts owed to foreign creditors fell into partial suspension, although systematic data on the extent of debt servicing by nonfinancial corporate borrowers are not available.

In Indonesia the situation became more chaotic, rather than less, in the early weeks of January 1998. The critical turning point was January 6 , when the government announced its proposed budget for the new fiscal year (that is, starting April 1). The budget called for a 32 percent increase in spending, in nominal rupiah terms. The proposal immediately was strongly denounced by the U.S. Treasury and the IMF as being inconsistent with the loan program, signaling that Indonesia was 
Figure 9. Indonesia: Policy Events and Stock Prices, July 1997 to March $1998^{a}$

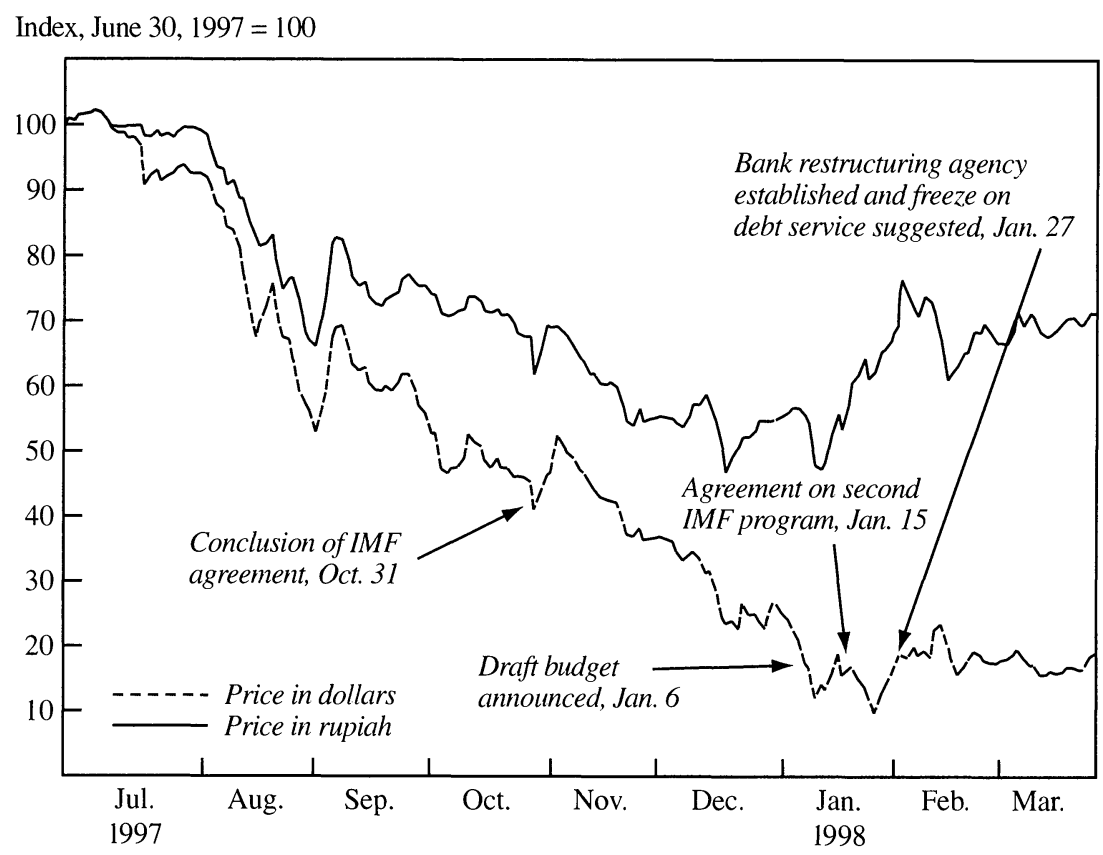

Source: See figure 7.

a. Data are daily, June 30, 1997 through March 23, 1998, and tic marks correspond to the first day of the given month.

not serious in implementing that program. Since the IMF loan program was confidential, these claims could not be independently verified by outsiders and the markets plummeted. In the event, the statements from Washington turned out to have been too hasty. The increased spending was entirely due to pass through effects of the depreciation; in real terms, the budget represented a reduction in spending. Several days later, Stanley Fischer from the IMF was quoted as saying that the new budget was "not as bad as it was portrayed," and within a few weeks the IMF had approved a budget with a 46 percent increase in spending. ${ }^{38}$ By that time, however, the damage had been done.

On January 15 the Indonesian government and the IMF signed a new agreement, revising that of November 1, 1997. In this case, the new agreement did not reflect a new strategy-there was neither a consoli-

38. “IMF's Fischer Says Indonesia Budget Not as Bad as Portrayed,' worldwide web page of Bloomberg, January 8, 1998. 
Table 16. IMF and Market GDP Growth Rate Forecasts for Indonesia, Korea, and Thailand

Percent

\begin{tabular}{llcr}
\hline & & \multicolumn{2}{c}{ Growth forecast } \\
\cline { 4 - 4 } Country and forecast source & \multicolumn{1}{c}{ Date } & 1997 & 1998 \\
\hline Indonesia & & & \\
IMF, first program & Oct. 31, 1997 & 5.0 & 3.0 \\
IMF, second program & Jan. 15, 1998 & & 0.0 \\
IMF, third program & Apr. 10, 1998 & & -5.0 \\
IMF, World Economic Outlook & Apr. 1998 & & -5.0 \\
Market forecast & Feb. 1998 & & -8.8 \\
Korea & & & \\
IMF, first program & Dec. 4, 1997 & 6.0 & 2.5 \\
IMF, third program & Feb. 7, 1998 & & -0.8 \\
IMF, World Economic Outlook & Apr. 1998 & & -2.5 \\
Market forecast & Feb. 1998 & & \\
Thailand & & & 3.5 \\
IMF, first program & Aug. 20, 1997 & 2.5 & 0.0 to 1.0 \\
IMF, second program & Nov. 25, 1997 & 0.6 & -3.0 to -3.5 \\
IMF, third program & Feb. 24, 1998 & & -3.1 \\
IMF, World Economic Outlook & Apr. 1998 & & -6.0 \\
Market forecast & Feb. 1998 & & \\
\hline
\end{tabular}

Source: International Monetary Fund forecasts are from various IMF press releases and IMF (1998c). Market forecast is a simple average of forecasts by Goldman Sachs and two other investment banks operating in the region.

dated rollover of private sector debts, as in Korea, nor a public guarantee of bank liabilities, as in Thailand. It simply intensified the previously agreed strategy, based on the IMF loan package and accelerated structural reforms. Once again, the strategy failed to revive market confidence. The markets in fact reacted negatively to the new package, with further declines in the exchange rate.

The turn toward a modicum of financial market stabilization in Indonesia came two weeks later, with two policy announcements by the government: first, a de facto suspension of payments on short-term debt; and second, the guarantee of all commercial bank liabilities, both to foreign and domestic depositors and other creditors. Despite considerable other turmoil during the following weeks-including the government's flirtation with a currency board, the reelection of President Suharto, and the replacement of the cabinet-the steep decline of the rupiah was halted. The announced suspension of debt payments, in one sense, merely confirmed the actual state of affairs, since most corporate 
debts were not being repaid. Nonetheless, the recognition that debt payments could in fact be delayed without a punitive response from the IMF calmed the markets. The Indonesian government announced that it would establish a framework for the orderly negotiation of debt restructuring, but such a framework has yet to be implemented.

On Friday, April 10, 1998, Indonesia signed its third agreement with the IMF in six months. This agreement did include provisions on restructuring private sector foreign debt and a more comprehensive strategy for reorganizing the commerical banks. It also eased requirements on fiscal stringency and the timetable for removing subsidies. The initial market reaction was favorable, and the rupiah had appreciated 6 percent by the following Monday.

It is important to note that the achievement of currency market stability across the region during the first quarter of 1998 (and nominal appreciation, in the cases of Korea and Thailand) came in conjunction with the relaxation of IMF fiscal targets. The IMF has relented on its goal of fiscal surpluses in 1998, and under the revised programs, each country will aim for modest fiscal deficits. The currency markets have demonstrated that exchange rate movements are not closely linked to the realization of budget surpluses.

While the IMF did not formally articulate a change of strategy after December 1997, certain new principles in its management of the crisis are clear:

-partial suspension of foreign debt payments, based on collective agreements between creditors and debtors (as in Korea) or unilateral actions to be followed by creditor-debtor negotiations (as in Indonesia);

- government guarantees of all bank liabilities-in contrast, for example, to the original program for Indonesia, which protected only small depositors in the banks that were closed;

- reduced focus on bank closures in the short term and more focus on longer run restructuring and bank recapitalization-for example, the IMF dropped a demand for further bank closures in Indonesia that it had tabled in discussions in early January; and,

- the abandonment of fiscal surplus targets.

Some principles, though, remain unchanged, in particular, the targeting of exchange rate stability through high interest rates and restrictive domestic credit policies; and the implementation of a wide range of structural measures in finance, trade, and corporate governance. 


\section{Why Did the Original IMF Programs Fail?}

The Asian countries were suffering an extreme contraction of economic activity in early 1998, despite the commitment of $\$ 110$ billion in emergency international support. The IMF programs failed to achieve their goal of maintaining moderate economic growth in these countries. They also failed in several intermediate goals, including the preservation of creditworthiness, the continuation of debt payments, and the stabilization of exchange rates at the levels prevailing when the original lending agreements were signed. It is crucial to understand what went wrong in order both to redesign these programs most effectively and to prepare for future international support efforts in other countries.

In the simplest terms, the IMF was not able to reestablish market confidence in time to prevent the collapse of debt servicing or achieve the early stabilization of exchange rates. In our view, there are five reasons for that failure. First, the IMF is rather poorly placed to rally market confidence in the short term, under any circumstances. Its arrival gives all the confidence of seeing an ambulance outside one's door. Second, the IMF greatly amplified the jitters that it naturally creates by declaring - both for the purpose of negotiation and in reflection of the substantive beliefs of the institution - that the East Asian financial crisis was mainly the result of deep fundamental weaknesses, rather than a self-fulfilling panic among creditors. In regard to Korea, for example, the IMF argues that "while the contagion effects of developments in Southeast Asia contributed to the current crisis, the magnitude and speed of deterioration in the financial situation owed much to the fundamental weaknesses in Korea's financial and corporate sectors." ${ }_{39}$

Third, the IMF's approach to restoring market confidence was based on a very peculiar hypothesis: that tough action on restructuring financial markets-including closing financial institutions, tightening regulatory standards, and the like-would reassure creditors so much that they would roll over their short-term claims as they fell due. The official press release from the IMF announcing the first program for Thailand declared: "At the heart of the strategy has been the up-front separation, suspension, and restructuring of unviable institutions, immediate steps to instill confidence in the rest of the financial system, strict conditionality on the extension of FIDF [Financial Institutions Development 
Fund] resources, and the phased implementation of broader structural reforms to restore a healthy financial sector. Recognizing that the financial system will face deteriorating conditions for some time, the authorities will require all remaining financial institutions to strengthen their capital base expeditiously." ${ }_{40}$ We have discussed at length the problems that existed in many banks and financial institutions across the region and the consequent need for reform. The key issues are how to introduce such reforms and over what time frame, especially in the midst of an incipient creditor panic.

There is no reason to believe that closing banks and finance companies and tightening supervisory standards would in fact restore market confidence in the middle of a panic, in the sense of stemming demands for the repayment of short-term debts. Indeed, the logic of creditor panics is the opposite: the sudden realization that a bank will not be bailed out by a lender of last resort can easily incite a panic that would not have arisen. Charles Kindleberger points out that decisive regulatory actions have often triggered panics rather than calm:

Apart from lags and mistakes of discount policy, the authorities may precipitate panic by brusque action in early stages of distress. In the summer of 1836, with credit extended in acceptances drawn by American houses on British joint-stock banks, the Bank of England refused to discount any bills bearing the name of a joint-stock bank and specifically instructed its Liverpool agent not to rediscount any paper of the three socalled "W banks" (Wiggins, Wildes, and Wilson) among the seven American banks in Britain, an action that "seemed vindictive" and led immediately to panic. As it turned out, the Bank of England had to reverse its policies. It had long conferences with the "W banks" in October, extended them lines of discount in the first quarter of 1837 , but failed to prevent their failure in June of that year. The Bank's instinct was right: to frustrate the extension of dangerous credit. But credit is a delicate thing. Expectations can quickly be altered. Something, sometimes almost nothing, causes a shadow to fall on credit, reversing expectations - and the rush for liquidity is on. ${ }^{41}$

The IMF's actions in Indonesia were particularly egregious. Under the program of November 1, 1997, sixteen commercial banks were

40. “IMF Approves Stand-By Credit for Thailand," International Monetary Fund Press Release 97/37, August 20, 1997, p. 3.

41. Kindleberger (1996, p. 96). 
suddenly closed with the explicit proviso that deposits over 20 million rupiah (the equivalent of approximately $\$ 5,000$ at the time) would be unprotected. The IMF does seem to have been aware of the risk of the policies: "During this process of financial sector restructuring, a key objective will be to ensure that confidence in the remainder of the banking system is maintained. The authorities are mindful of the risk that bank closures could induce a run on other healthy institutions. ${ }^{, 42}$ In the event, the bank closures provoked a financial panic and a run on the entire private sector banking system other than foreign-owned institutions. As the IMF dryly observed in January 1998:

Following the closure of 16 insolvent banks in November last year, customers concerned about the safety of private banks have been shifting sizeable amounts of deposits to state and foreign banks, while some have been withdrawing funds from the banking system entirely. . . . These movements in deposits have greatly complicated the task of monetary policy, because they have led to a bifurcation of the banking system. By mid-November, a large number of banks were facing growing liquidity shortages, and were unable to obtain sufficient funds in the interbank market to cover this gap, even after paying interest rates ranging up to 75 percent. At the same time, another smaller group of banks [that is, the state and foreign banks] were becoming increasingly liquid, and were trading among themselves at a relatively low JIBOR (Jakarta Interbank Offer Rate) of about 15 percent. As this segmentation continued to increase, while the stress on the banking system intensified, Bank Indonesia was compelled to act. It provided banks in distress with liquidity support, while withdrawing funds from banks with excess liquidity, thereby raising JIBOR to over 30 percent in early December, where it has since remained. . . Nevertheless, despite this increase in interest rates-to levels higher than in any other country in the region-the problems of the rupiah have only intensified. ${ }^{43}$

Across the region, even relatively strong banks came under intense pressure as foreign creditors refused to roll over loans and depositors fled to state and foreign owned banks. By January 1998, the banking systems of Indonesia, Korea, and Thailand had nearly ground to a halt. Foreign banks stopped accepting letters of credit written by banks in these countries, and firms had difficulty in finding new banks to service

42. International Monetary Fund (1997a, p. 18).

43. International Monetary Fund (1998b, p. 4-5). 
their needs. Ironically, even exporters were badly affected, despite the potential for increased profitability from the exchange rate depreciations. There were widespread reports of exporters with confirmed orders being unable to obtain needed trade credits because banks were not making new loans. In Thailand, exports in January 1998 were 8 percent below the level of January 1997. Prime Minister Chuan Leekpai attributed the problem to the banking sector, noting that "the major problem we are facing with regard to exports is that of liquidity. The banks are charging high interest rates, and some banks do not have the funds to make loans." ${ }_{44}$ For similar reasons, Indonesian shoe manufacturers appealed to their government for emergency credits. Despite an estimated $\$ 1$ billion in confirmed export orders for the first six months of 1998 , these firms were unable to arrange for the working capital credits to import the inputs-representing roughly 60 percent of the final price of exports-needed to produce the shoes.

The fourth reason why the IMF failed to achieve confidence and exchange rate stability in East Asia involves its approach to fiscal and monetary policy. The IMF put great emphasis on the need for strong fiscal contraction in order to ensure a fiscal surplus in 1998, even though the crisis countries were already hit hard by the contractionary force of the withdrawal of foreign credits. We have noted that Thailand was asked to take fiscal contractionary adjustments equal to approximately 2.6 percent of GDP (from a deficit of 1.6 percent of GDP in fiscal year 1996-97 to a surplus of 1 percent of GDP in fiscal year 1997-98); Indonesia was required to take fiscal contractionary actions equal to 1 percent of GDP in fiscal year 1997-98 and 2 percent of GDP in fiscal year 1998-99; and Korea was asked to take adjustment measures equal to 1.5 percent of GDP in 1998-99. The IMF asserted that such adjustments were a core component of the confidence-building measures needed for currency stabilization. Yet there is no evidence that the currency markets reacted at all favorably to the fiscal surplus targets. They certainly did not react adversely when the IMF eased the fiscal targets in early 1998.

The monetary targets are a more conventional approach to financial stabilization. The IMF used interest rates both as instruments and as

44. Quoted in Peter Montagnon, "Export Slowdown Hits Thai Recovery,' Financial Times, April 3, 1998, p. 6. 
intermediate targets. Most macroeconomists share the view that increasing interest rates will help to support currency stabilization, but this basic proposition becomes problematical-even doubtful-in the context of an extreme creditor panic. Kindleberger's survey of past manias and crashes makes clear that interest rate increases can actually work against currency stabilization under these circumstances: "Tight money in a given financial center can serve either to attract funds or to repel them, depending on the expectations that a rise in interest rates generates. With inelastic expectations-no fear of crisis or of currency depreciation-an increase in the discount rate attracts funds from abroad and helps to provide the cash needed to ensure liquidity; with elastic expectations of change-of falling prices, bankruptcies, or exchange depreciation-raising the discount rate may suggest to foreigners the need to take more funds out rather than bring new funds in." 45 The point is not just a theoretical curiosity: the experience of the Asian currencies in the second half of 1997 gives direct empirical support.

Consider the case of Indonesia in the lead-up to its initial IMF program of November 1, 1997. At the time, the IMF noted that "the downward pressure on the rupiah has persisted despite policy measures that, by and large, have been timely and broadly appropriate. [In August] liquidity conditions in domestic money markets were tightened significantly with one month interest rates on central bank certificates . . . being increased from $11 \frac{1}{2} 2$ percent to 30 percent on August 19.", Fiscal policy was also tightened. The IMF went on to observe, however, that "this policy response initially had a salutary effect on the exchange rate, but this respite did not last long. The tightening of monetary conditions transferred market pressures to the domestic economy, putting heavy strains on the already-weak financial sector. As a consequence, a significant number of banks found themselves without sufficient resources to meet their payment obligations . . . . The authorities, and market participants, soon realized that the banking system could not bear this stress for long." Eventually, the central bank had to provide emergency liquidity financing, and the rupiah had again fallen under significant pressure by the end of September. The idea that high interest rates could stop the panic essentially had been tested and proved incorrect before the start up of the IMF program. ${ }^{46}$

45. Kindleberger (1996, p. 8).

46. International Monetary Fund (1997a, pp. 8, 9). 
Yet the same strategy was pursued in the formal IMF program launched on November 1. It was alleged that the combination of tight monetary policy and "decisive actions to address the fundamental weaknesses of the economy" would solve the problem. Once again, the higher interest rates had little positive effect, however. Indonesia's second letter of intent, quoted above, notes that although interbank rates were raised to over 30 percent in early December, the problems with the rupiah intensified.

A fifth important reason for the failure of the IMF programs is that the loan packages provided only a weak shadow of a lender of last resort facility. While we are not enthusiastic about casting the IMF as a true international lender of last resort (see below), we would emphasize that announcing large sums of money that are not readily available for short-term support is unlikely to stop a creditor run.

Under the IMF programs in East Asia, it is not clear how much money is actually available to each country: substantial sums are announced as contingency funding from bilateral supporters, but the conditions for their use are not defined and are subject to future IMF staff appraisals and negotiations with the bilateral creditors. Turning back to table 15 , we try to assess the money that is really in hand. Commitments were made as first and second lines of defense. The first line of defense consisted of funding from the IMF, the World Bank, the Asian Development Bank (ADB), and in the case of Thailand, from bilateral donors. The loan packages commit to provide funding for three years, and the money is tranched-that is, available only in "slices" over the program period. Moreover, funding from the World Bank and the ADB is predicated on the negotiation of separate agreements related to financial markets, social policy, and other substantive areas. By the end of December 1997, in Thailand, $\$ 7.3$ billion of the original $\$ 17.2$ billion in commitments had been disbursed. In Korea, $\$ 13.2$ billion of the $\$ 57.0$ billion committed had been disbursed, largely as a result of the emergency acceleration of disbursements on December 24. None of the second line funding had been disbursed in Korea by the end of March 1998. In Indonesia, only $\$ 3$ billion of the promised $\$ 40$ billion had been disbursed by the end of March 1998, and this did not include any money from the World Bank, the ADB, or the bilateral second line donors. The amounts of money that were disbursed in each country are very small, compared with the short-term debts falling due. Unlike a 
true lender of last resort, which provides the full amount $(L=\theta D)$ needed for debt servicing, the IMF put only a small proportion of that funding directly on offer through its loan packages.

When one examines the IMF programs with care, one can see that they were predicated on the very optimistic assumption that short-term debt would be rolled over. For Indonesia, for example, the baseline program projected the voluntary rollover of short-term debt at twothirds of the amount falling due ${ }^{47}$ The baseline assumptions for Korea and Thailand were even more optimistic. The Thai program assumed that "short-term lines to Thai banks ( $\$ 11$ billion, much of which have been undertaken by the five largest) will also be broadly maintained.",48 In the case of Korea, the IMF's working assumption was "that, on the basis of the beneficial effects on market confidence of the announced program and the large financing package, the bulk of the short-term debt [would] be rolled over. " 49 While these programs did include provisions for contingencies, these could only be triggered as extraordinary events. And in fact on December 24, 1997, after considerable public hand-wringing by U.S. and Korean officials, $\$ 10$ billion of the second line of defense funding was activated in Korea. Under such circumstances, the lender of last resort effect is not really secured. Creditors essentially still face a one-way bet: either to leave their money in the country, with a real risk of imminent default or forced rollover-which is what happened in Korea-or to take it out at little cost, to see whether enough contingent funds will indeed be made available.

In two other regards, the IMF programs in East Asia are far from optimal for restoring financial market confidence in the short term. First, they have covered a very wide range of policies beyond the immediate financial crisis, including trade liberalization, demonopolization, privatization, and so forth. Such reforms may well be desirable, and some-for example, eliminating monopolies that effectively have open lines of credit with the commercial banks-may be germane to strengthening the weak banking sector. Most of the structural reforms, however, simply distract attention from the financial crisis. They have taken government expertise, negotiating time, and political capital 
away from the core issues of financial markets, exchange rate policy, and the like. ${ }^{50}$

Second, the initial loan programs were not released to the public. This secrecy, a traditional feature of IMF loan agreements, proved a major liability in the Asian context, since the programs aimed in large part to restore public confidence in the short term. Fortunately, the second round of programs have been made public; since February 1998, they have even been posted at the IMF's worldwide web site.

\section{An Evolving Framework for 1998}

The East Asian financial crisis will take a very serious toll on the region's economies in 1998. The depth of the crisis, however, is still to be determined. Though Asian financial markets have begun to regain strength in early 1998, the real effects of the reversal of credit flows have yet to be felt. The effective time-outs on debt servicing in Korea and Indonesia - the former by negotiation, the latter by default-have given some breathing space for longer term solutions. Several urgent issues remain to be addressed.

The overhang of short-term debt will continue to plague all three major crisis economies. Korea's time-out lasts until the end of the first quarter of 1998, and considerable amounts of short-term debt remain to be paid during the remainder of the year. In April, however, Korea was able to return to the markets and effectively refinance some debt payments with a new bond issue of $\$ 4$ billion. ${ }^{51}$ Indonesia has yet to negotiate a formal rollover or standstill on debt payments, and a large proportion of its corporate external debt is now in outright default. The experiences of Mexico and Argentina suggest that bank creditors are likely to continue to demand repayment of short-term debts as they fall due, even if new foreign investors begin to enter these economies.

There is a reasonable chance that all three economies will need a further stretching out of debt payments for the remainder of 1998. If there is a renewed significant net outflow of funds, debt restructuring

50. See Feldstein (1998) for a critique of IMF programs along these lines.

51. On April 8, 1998, Korea sold $\$ 1$ billion in five-year government notes (at 335 basis points over the London interbank offer rate [LIBOR]) and $\$ 3$ billion in ten-year notes (at 345 basis points over LIBOR). The issue was reportedly substantially oversubscribed, and the government immediately initiated plans for another offering, pending an expected ratings upgrade. 
should be carried out in an orderly manner, without desperate measures to avoid another round of negotiation. There is no justification, for example, for boosting interest rates yet again in order to forestall concerted rollovers of short-term debts. Furthermore, the IMF and the Asian countries should insist on restructuring the debt, rather than drawing down IMF funds. Not only do concerted workout arrangements introduce much less moral hazard in rescue operations, but as we discuss below, there are far more effective ways to use IMF program funds than simply to recycle them to international creditors.

The banking sector remains illiquid and heavily undercapitalized in each of the crisis countries. Given that the banks are net borrowers from abroad, the sharp real depreciations of these currencies almost surely has meant that a large proportion of net worth has been wiped out. On paper, the banks have generally tried to hedge their positions, keeping dollar-denominated lending roughly in balance with dollardenominated borrowing. Since much of that dollar lending has been to domestic investors that will face bankruptcy in the wake of the sharp exchange rate depreciations, however, even banks that are hedged on paper will suffer a large loss of net worth. Not surprisingly, the early evidence suggests that rates of nonperforming loans are soaring. Even more dangerous, almost all nonforeign commercial banks in Indonesia, and many in Thailand and Korea, have been so sharply downgraded as credit risks that they are no longer able to open letters of credit recognized by international banks. As noted above, Asian exporters have consequently been facing a sharp credit squeeze, which is preventing many of them from responding to the huge rise in profitable opportunities following the currency depreciations.

In the short term, a portion of the emergency IMF loans could be used to create dedicated pools of working capital to help finance credits for exporters; for example, by guaranteeing letters of credit opened by commercial banks. In the medium term, the commercial banks will have to be recapitalized and floated again to private investors. There are many possible models for bank rehabilitation. Typically, they require an infusion of public funds to reestablish the positive net worth of insolvent banks; temporary transfer of ownership of the insolvent banks to a public intermediary; and the resale of the banks to the private sector, with both foreign and domestic investors invited to provide fresh capital. There is also an important need to mobilize public funds to 
back the recent public guarantees of bank deposits and liabilities. Part of the IMF loan program could usefully be dedicated to establishing a rudimentary deposit insurance fund, as a way to strengthen public confidence in the banking sector.

In parallel with bank restructuring and capitalization, enterprise restructuring and capitalization must take place in the nonfinancial corporate sector. Each of the three crisis countries is in the process of establishing new bankruptcy mechanisms to facilitate financial reconstruction in the corporate sector. This will include the widespread conversion of debt to equity, and the transfer of equity in insolvent enterprises from existing shareholders to creditors.

Another portion of the IMF funds should provide the gross reserves needed to back more appreciated exchange rates in these countries. Exchange rate targets failed in the second half of 1997 because they were overwhelmed by panicked withdrawals of loans. New exchange rate targets will be viable if accompanied by realistic rescheduling of the foreign debt obligations falling due in the year. There is little case for a return to pegged exchange rates, and still less for the establishment of currency boards. Nonetheless, the availability of adequate gross reserves will surely help to establish greater market confidence, and thus might make it possible to nudge the real exchange rates of the Asian countries toward more realistic postpanic levels.

\section{Preventing or Managing Future Crises}

Current arrangements for integrating emerging markets into the global financial system are clearly defective. Capital market liberalizations in Latin America, eastern Europe, and Asia have been followed by extreme macroeconomic crises. The IMF's responses to those crises have not prevented deep dislocations in the emerging market countries. Moreover, the emergency IMF bailout packages in Mexico, Argentina, and East Asia have arguably contributed to significant new moral hazards in international lending. The IMF has shown itself to be extremely fearful of a default in any major emerging market, and in fact, prepared to devote large sums of money to bailing out foreign credits. Deputy Treasury Secretary Lawrence Summers has described the current system as one in which policymakers often "confront the choice between un- 
controlled chaos and confusion on the one hand and large bailouts on the other." 52

We argue that international financial markets are inherently unstable, at least for countries borrowing heavily from abroad at short maturities and in foreign currency. It may be true that better banking supervision would solve the problem of unstable capital markets, although many advanced economies have suffered enormous banking crises following financial market liberalization, as did Sweden in the early 1990s. Thus the rapid push toward fully open capital markets among the developing countries would seem to be misguided. There is certainly no strong empirical evidence that economic growth in middle-income developing countries depends on unfettered access to short-term capital flows from abroad. Such short-term financing is useful for trade flows, but not for longer term investments. And short-term inflows have still less use in financing long-term on-lending by highly leveraged financial institutions. The notion that improved supervision will quickly render shortterm capital flows benign is unproven-and unlikely, in our opinion.

The policy goal should be to support long-term capital flowsespecially foreign direct investment-and equity portfolio flows, but mainly to limit short-term international flows to the financing of shortterm trade transactions. Banks and nonfinancial corporations could be discouraged from short-term international financing (with maturities of under six months, for example), except to finance documented trade transactions. One could approach such limits through taxation-as does Chile, which imposes a 30 percent reserve requirement on dollar deposits in the banking system-or through outright supervisory limits. Practical enforcement considerations, such as administration and monitoring, would probably push toward outright quantitative limits on short-term flows, even though economic arguments would generally favor taxation. The argument that short-term flows essentially cannot be controlled, because of poor monitoring or access to financial derivatives that allow controls to be circumvented, is not convincing. The huge buildup of short-term debts in Asia in the 1990s followed hard on the heels of a specific set of financial liberalization actions. It is fair to contend that without institutional innovations such as the Bangkok Inter-

52. Lawrence Summers, "Go with the Flow,"' Financial Times, March 11, 1998, p. 14 . 
national Banking Facility, the Thai buildup of debt could well have been contained. Similarly, the buildup of short-term debt in Korea was a consequence of the regulatory treatment of Korean merchant banks in the mid-1990s. Some short-term capital will always evade any taxation or quantitative controls, but the evidence from Chile and Malaysia suggests that such tools can be effective at slowing such inflows on the margin.

Ironically, the IMF has been pushing the Asian countries toward accelerated capital market liberalization in the wake of the crisis. For example, the December 3, 1997, program for Korea announces that "the government plans to accelerate substantially its ongoing capital account liberalization. . . . In order to instill market discipline a timetable will be set by end-February 1998 to eliminate restrictions on foreign borrowing by corporations," among other measures. ${ }^{53}$ According to our analysis, such a push toward further liberalization of longterm capital flows, including foreign direct investment, has little riskand probably significant long-term economic benefit. The problems arise mainly from the lack of any distinction between short-term and long-term capital flows.

While the liberalization of short-term capital movements should be undertaken only gradually and with extreme caution, opening the financial sector to foreign direct investment should probably be much more rapid and forthright. When the crisis erupted, Indonesia, Korea, Malaysia, and Thailand were all characterized by the limited presence of foreign bank branches and subsidiaries. Despite their significant interest, foreign banks were generally unable to obtain general banking licenses, due to protectionism in support of domestic banks. The presence of more foreign banks would almost surely have helped to calm the Asian financial crisis, for several reasons. First, branches of major international banks would have been much less subject to depositor panics than were domestic banks; indeed, in Indonesia, depositors fled from the national banks to the few foreign banks, and also to stateowned banks. Second, foreign banks would have been less likely to withdraw their own loans to local customers than to withdraw their cross-border credits to Asian banks. Third, they would have raised the general level of competition in the banking system and might well have helped to limit the politicization of bank ownership and bank lending.

53. International Monetary Fund (1997b, p. 10). 
We also argue that the IMF's bailout lending has been ineffective, probably intrinsically so. The IMF is unable to be a true lender of last resort. Its loans will always be sufficiently restrictive, conditional, and tranched to leave lingering doubts in the markets, and therefore leave room for "rational" panics. With the announcement of an IMF loan package, short-term claimants still have the preferred option of withdrawing their loans and waiting to see what will happen in the future. The provision of IMF loans is therefore unlikely to staunch a panicked outflow of loan capital. The result may be the worst of both worlds. On the one hand, the panic continues, with adverse macroeconomic consequences. On the other hand, the foreign lending is socialized (that is, repaid by the public sector), with objectionable distributional consequences, since the foreign banks get bailed out at the expense of the taxpayers of the emerging markets, and deep problems of moral hazard.

The Korean episode points to a better approach: orderly workout arrangements that rely on private sector funds rather than on bailout loans from the IMF. ${ }^{54}$ The analytical starting point for this approach is the recognition that chapter 11-style bankruptcies in the United States (or chapter 9 , in the case of municipalities) create a negotiating framework for creditors and debtors that overcomes many of the collective action problems inherent in financial crises. A bankruptcy arrangement typically involves a standstill on debt servicing, such as that in Korea in the first quarter of 1998; an arrangement for tapping private capital markets for interim financing-so-called debtor-in-possession financing, under section 364 of the U.S. Bankruptcy Code; and a system for debt reduction and debt-to-equity conversion that overcomes the inevitable free-riding among creditors in the course of debt restructurings.

The provision for debtor-in-possession financing is critical. Under bankruptcy law, the general idea is that the bankruptcy court can enable the bankrupt debtor to tap the private capital markets by granting priority in the repayment queue to the new loans. In our context, it would be as if Korea could have gone to the Eurobond markets in December 1997 with the enforceable legal right to borrow fresh loans that would be repaid ahead of all of the existing credits. In this way, the bankruptcy court is able to get working capital to the bankrupt debtor, despite the fact that the court (in contrast to the IMF) cannot tap official funding sources. 
International workout arrangements could be modeled on the chapter 11 process. When a sovereign borrower faced imminent default, a standstill on debt servicing would be triggered (and perhaps officially approved by the IMF's Executive Board). The debtor country would fall under the protection of the IMF, which would facilitate negotiations between the debtor and private sector creditors to restructure the repayment program. The plan would be conditioned on economic reform measures agreed by the debtor country. The IMF would also facilitate interim financing, not by directly making available official funds, but rather by overseeing new priority borrowing by the debtor country. In this way, the debtor country would be able to tap the capital markets despite the standstill on repayments of the earlier debt. A candidate for this type of arrangement would have been Mexico in 1995 .

When there is a mass exodus from private sector debtors, as in the East Asian crisis countries, the situation is much more complex. Under those circumstances, the individual bankruptcy model applied on a case-by-case basis will not resolve a financial panic in a timely and efficient way. It may still be necessary to impose a generalized standstill on debt servicing, followed by a mechanism to bring the various international creditors and national debtors under one roof for a collective renegotiation and rollover of debts-just as occurred in Korea in late December 1997 and early January 1998. Thus designers of orderly workout mechanisms might have to contemplate provisions for acrossthe-board standstills and rollovers of debts at the country level, even though the debts are in fact owed by individual private sector entities. The IMF's Interim Committee acknowledged the need to “involve private creditors at an early stage, in order to achieve equitable burden sharing vis-à-vis the official sector and to limit moral hazard.',55

The Korean negotiations demonstrated that such a mechanism can work in practice. Now, we suppose, economists will have to discover whether it can work in theory-and thereby be pursued more systematically in future cases. The better hope remains that prudential restrictions on short-term capital flows and greater market sensitivity to the risk of panic will render the need for such extraordinary interventions much less likely, by limiting the buildup of unstable short-term debts before a crisis occurs.

55. International Monetary Fund (1998a, sect. 3[e]). 


\section{Comments and Discussion}

Richard N. Cooper: This paper offers a useful, comprehensive discussion of the East Asian financial crises. I emphasize the plural because, in my judgment, what occurred in the second half of 1997 was not a single crisis; it was a series of crises, not completely unrelated to one another. But if one looks under the rug, the details differ in important ways from one country to another.

Stephen Radelet and Jeffrey Sachs emphasize that, among the various types of crisis, these were overwhelmingly financial panics calling for remedies very different from those for a normal financial crisis. They consequently blame the International Monetary Fund for not helping, and in some respects actually aggravating, the crises. The authors have the advantage of hindsight: they are in the luxurious position of engaging in Monday morning quarterbacking. The relevant question is not whether the IMF made mistakes-it surely did-but whether it made mistakes ex ante, given what it could have known at the time.

Indeed, the authors emphasize how little these crises were actually forecast. The following assessment appeared in a highly reputable financial newsletter published by the Chase Manhattan Bank on October 1, 1997, three months after the crisis in Thailand had erupted and in the face of substantial declines in stock prices as well as currency depreciation:

The weakening of the other Asian currencies is less a result of "contagion" than a reaction by investors-and policymakers-to new facts. That said, economic fundamentals and policy management are stronger in the other Southeast Asian nations, which will experience both a more 
moderate decline in growth this year and a more rapid rebound than Thailand next year. As the foreign exchange market begins to stabilize, these differences in performance and policy will be reflected in each country's currency. ${ }^{1}$

That is a relatively complacent, but fairly typical, statement. It continues: "growth [in Korea] will slow in any case because of the restructuring of major industrial conglomerates (chaebol), weak domestic demand, and problems in the banking system. Overall, Asian growth is expected to decline by about two percentage points next year, to $6 \frac{1 / 2}{2}$ percent."' The sharp declines experienced after mid-October were not foreseen by mainline financial analysts.

Radelet and Sachs identify four key elements of the IMF programs: fiscal policy, monetary policy, bank closings, and the rebuilding and recapitalization of banks. They argue that all were misguided. Here, I discuss these elements in an ex ante sense rather than in an ex post sense. I disagree with the authors on the first two but I agree with them on the last two.

Let me address fiscal policy. I focus on Thailand, because that was the first crisis and called for the largest fiscal contraction. In its support program of August 1997, the IMF required a country that had nearly balanced fiscal accounts to achieve a surplus of 3 percent of GDP. Some observers thought that the IMF was applying its usual prescription inappropriately.

It should be kept in mind, however, that Thailand had a current account deficit of 8 percent of GDP in a period when, as the authors emphasize, private capital inflows were drying up. The Thais did not disagree that they needed a substantial reduction in their current account deficit. Economists do not know how to manipulate private saving. The one way we know of manipulating national saving, more or less reliably, is through the fiscal accounts. The fiscal tightening in Thailand, following a substantial depreciation of the currency, represents a combination of expenditure switching toward net exports and a necessary reduction in domestic expenditure. That is standard prescription under the circumstances and is not obviously inappropriate.

1. "Emerging Markets After Thailand: Guilt by Association or Flattered by the Comparison?', The Chase Manhattan Bank, October 1, 1997. 
The IMF's fiscal target for Thailand was predicated on a 3 percent growth rate in 1998. That raises an interesting question about how these loan programs are put together. The "letter of intent" is technically written from the country in question to the IMF. To its credit, Thailand makes its intent public; not all countries do. In August 1997 the Thai authorities did not want to admit publicly that they foresaw a growth rate below 3 percent, already a substantial reduction from that of 1996 . What does the IMF do under such circumstances? In this case, it set the fiscal target in accordance with a projected growth rate which at least some of its own analysts knew to be wrong.

It is standard procedure for the IMF to review its programs quarterly to assess progress and make adjustments in light of new circumstances. At the first quarterly review, and then again at the second, the IMF essentially held Thailand to the expenditure levels and tax rates of the original program, recognizing that the country would not achieve a budgetary surplus exceeding 2 percent of GDP. In other words, it allowed the fiscal stabilizer to work. One may differ in one's judgment about these matters, but that does not strike me as an obviously wrong approach, given what the Thai and the IMF authorities knew during August, when the program was agreed.

In contrast to the issue of fiscal policy, I agree with Radelet and Sachs on the question of bank closings and bank recapitalization. Both were clearly required. But it is highly risky to announce in advance that certain banks are going to be closed, without having in place a program to reassure depositors about the security of their deposits and of the survival of the remaining banks. Moreover, high capital requirements for banks are intended to provide a cushion against unforeseen contingencies, as a shock absorber between assets and liabilities. It gets the matter backward to require that banks recapitalize as a precondition for dealing with a financial emergency. While they do have to recapitalize, to require that they do so in the first months of the program can aggravate rather than mitigate the problem.

The East Asian financial crises are complex, and the lessons that people draw will depend on what they bring with them. It is not entirely surprising that Jeffrey Sachs finds the International Monetary Fund deeply deficient. It will be equally unsurprising if members of the Cato Institute and many other folks around Washington discern in these crises 
the superiority of Anglo-Saxon capitalism over Asian capitalism (what is now loosely called crony capitalism). But that is not the lesson that will be drawn in Asia.

Officials in China and Vietnam-countries at different stages of economic reform-will be reinforced in their caution about the pace of liberalization. Unhappily, Vietnam may even bring reform to a complete halt for a while. Meanwhile, China has postponed full currency convertibility, which was originally targeted for the year 2000 , until well into the next century. In Thailand and Korea, some people will discover in these crises evidence that democratization was a serious mistake, and they will hanker after the strong man days of Sarit Thanarat in Thailand and Park Chung Hee in Korea.

One must be careful about overdrawing conclusions. Having said that, I believe that these crises underscore four fundamental points. The first, aimed mainly at economists, is that the financial system is a part of the fundamentals of every modern economy. It is a mistake to draw a sharp distinction, as economists routinely do, between the real and the monetary economy. This dichotomy has been so productive pedagogically that we focus too often only on real variables and neglect the financial system that lubricates them. We simply assume perfect arbitrage and implicitly dismiss the resources required to make it work. This relative neglect is all the more curious, in that in the American economy the financial sector generates nearly 6 percent of total employment, far more than the agricultural sector. In focusing on an economy's fundamentals, therefore, one should recognize that these include both the magnitude and the quality of its financial sector.

Second, 1997 revealed perhaps not a clash of civilizations, but a clash of cultures played out in the financial world. Foreign lenders based in London, New York, and other major financial centers expect to be kept well informed about what is happening in the economies to which they lend, and especially about what is happening to the borrowers. If borrowers are unexpectedly unable to repay on schedule, these lenders expect orderly procedures for working out the situation, preferably ones that maximize the likelihood of being paid without loss. In short, they expect transparency and well-defined processes.

Asian borrowers have a different tradition, which emphasizes personal-and political-connections and loyalties. They operate on the assumption that problems can be worked out satisfactorily behind closed 
doors. What foreign lenders or domestic depositors do not know will not hurt them; indeed, timely and accurate information may unduly alarm them. It should be noted that the Asian tradition, or something resembling it, was common in many European countries not long ago and its remnants are discernable even today.

It is difficult to pass judgment on the respective merits of these two quite different traditions. One can find circumstances in which one or the other is superior, but my main point is that they do not mix well. If foreign lenders suspect that serious problems are likely to arise with their Asian borrowers, they do not expect to be told how serious the problems may become and what the likely solutions will be. But neither do they expect to be treated equitably in the solutions that may be worked out behind closed doors. So they will simply withdraw their funds as rapidly as they can, thus turning a financial problem, or even a suspected financial problem, into a financial rout.

Third, the high-growth East Asian countries have been widely praised for their high saving rates, which permit high rates of investment even without the inflow of foreign capital. Household savings in this part of the world were traditionally held in the form of gold or silver jewelry, coins, leaves, or bars. During the past two or three decades, however, ordinary people have increasingly entrusted their savings to deposit-taking institutions, which, in turn, have been able to mobilize the savings for investment elsewhere in the economy. But such deposits involve an act of trust by the public at large. There is a corresponding obligation on the authorities to ensure that this trust is warranted and preserved.

The sad fact is that the public's trust has been badly abused in many Asian countries, including some that have not been caught up in the crisis, most notably China. Banks have used the deposits of ordinary people to make loans ranging from unrecoverable operating subsidies to favored enterprises to high-stakes gambles in urban real estate. One of the most important tasks of the monetary authorities in Asian countries is to rebuild the trust that has been eroded and to preserve it.

Fourth, the crises serve as a reminder that modern financial systems are intrinsically unstable. In their normal domestic operations, banks engage in maturity transformation, borrowing short and lending long. With the globalization of capital markets, they increasingly engage also in currency transformation. Such transformations are intrinsically risky, 
and they rely very much on the independence of large numbers of transactions to reduce the risk through diversification. Some, but not all, of the risk can be spread through skillful use of financial derivatives, although new risks, often not so evident, are thereby introduced. But when the independence of transactions disappears, as it does when the herd behavior of lenders takes over, possibly leading to stampedes, the underlying fragility of the financial system is revealed.

These are characteristics of all financial markets. In developed countries, years of often unpleasant experience have led to the construction of an elaborate structure to bound, bolster, and, if necessary, support the financial system against the worst consequences of its intrinsic instability. Elements of this structure include deposit insurance, capital requirements for deposit-taking banks and brokers, independent auditing, risk limitations (for example, on foreign currency exposure), close supervision, and a lender of last resort. It takes time, training, and experience to develop such comprehensive regulatory structures. They are only nascent in many low-income countries and at the international level.

Sadly, most societies find it difficult to learn from the experience of others-they learn mainly from their own mistakes. From this point of view, the 1997 crises may have been necessary steps in the learning process of rapidly developing economies. If the lessons are learned well, these countries will emerge the stronger for them, after a few years of economic pain. For its part, the international community should be spurred to work more aggressively toward developing internationally acceptable banking standards, and to ensure that it can provide financial support quickly and in sufficient magnitude when the need arises.

Barry P. Bosworth: In this broad-ranging paper, Radelet and Sachs relate the East Asian financial crisis to a large prior literature on the causes of such crises and the policy responses. The discussion is structured around three primary issues: the causes of the crisis, the appropriateness of the IMF response, and long-term crisis prevention.

The largest portion of the paper is devoted to the causes of the crisis. Historically, the debate has been divided between those who see currency crises as the result of deterioration in economic fundamentals within the affected countries ("it was their fault") and those who blame inherent instabilities in international capital markets (self-fulfilling 
prophecies). Radelet and Sachs provide a slightly different focus by distinguishing among internal fundamentals, external shocks, and systemic instability. However, the adverse external shocks that they can identify seem at best minor contributors to the crises. As they point out, the loss of trade shares to Mexico and China was small. And there is little evidence of seriously overvalued exchange rates. For example, the Korean won was devalued by 15 percent in nominal terms relative to the dollar between the end of 1995 and March 1997, and most measures of real exchange rates show very little appreciation on a tradeweighted basis. The one external factor that the authors do not emphasize is the role of Japan. Were not the incredible low interest rates in Japan a contributing factor? The fact that banks could raise deposit funds with a 1 percent deposit rate in Japan and lend at 10 percent in Korea must have been a significant inducement to the expansion of capital inflows.

Radelet and Sachs argue that the Asian crisis should be interpreted as an unforeseeable financial panic that cannot be traced to deteriorating fundamentals. With hindsight, economists can always unearth some policy errors, but I think that the authors are on the right side of this debate. The lack of evidence of significant foresight in markets or of strong contagion effects argues strongly for the self-fulfilling prophesy interpretation. In fact, most of the macroeconomic fundamentals looked quite good: low inflation, fiscal surpluses or small deficits, high rates of capital formation, and rapid growth. Although the Asian crisis countries had surprisingly large current account deficits, the capital inflows were associated with high investment, not consumption as in Mexico. If the disaster was due to policy error everyone is vulnerable, because the mistakes were certainly small and within the range of those committed by the industrialized countries .

The new focus in this paper is on weak banking systems. But these Asian countries were not unique in the low quality of their banking systems, at least as measured by rating services such as Moody's and Standard and Poor's. It was not so long ago that the development of extensive financial intermediation was being cited in the economic literature as a significant contributor to Asia's rapid growth. It is striking how quickly one can convert a positive into a negative. Furthermore, a heavy reliance on debt finance is often associated with high growth, since internally generated funds can only support slowly expanding 
enterprises. Equity markets are not frequently a significant source of new funds.

Even if bad banks posed a major problem, something else needs to be added to the mix in order to induce a crisis-capital convertibility. Both Thailand and Korea were faced with strong international pressure to open their financial markets to foreign investors, and in retrospect, the process was badly mismanaged. The industrial countries and the international institutions have made capital convertibility a high priority for many developing economies. However, the process of financial market reform is difficult, and the introduction of capital account convertibility in the early stages often leads to crisis. Ronald McKinnon and others have stressed the importance of getting the sequence of financial reforms right, holding off on capital convertibility until an open, well-functioning domestic financial system is in place. Those countries that were moving more slowly to open their financial markets had far fewer problems; Taiwan, for example, had no capital convertibility and no crisis.

Much of what Radelet and Sachs describe is very reminiscent of prior liquidity crises in industrialized countries and of old-fashioned bank runs. In particular, these Asian economies stand out for having incredibly low reserves relative to short-term liabilities; and in the empirical analysis, that is the only variable with major predictive power. Many of the reported reserves were either not available (Korea) or offset by large net positions in the forward market (Thailand). While the overall external debt of the Asian crisis countries may not have been excessive, the proportion in short-term liabilities was certainly extreme. But not only banks were exposed to currency fluctuations. Because of a strong government commitment to relatively fixed exchange rates, many traders, including large American export corporations, maintained substantial open positions. The break in the exchange rate initiated a rush to cover that exposure that greatly added to the demands for foreign exchange. Thus, while these countries may have faced some solvency problems in the internal economy, the fundamental external problem was liquidity.

The authors note the similarities between the recent Asian crises and the Mexican crisis of 1994-95, but the differences in the international response are striking. Mexico was provided with $\$ 52$ billion in loans with only limited conditions. It drew $\$ 32$ billion of those funds within 
a few weeks, stopped the crisis, and by the middle of the year had started repaying the United States and Canada. The United States has been fully repaid and netted a healthy profit.

In contrast, the funds offered to the Asian countries were highly conditional, and the amounts actually made available were far less than the $\$ 100$ billion prominently reported in the press. From the beginning, the IMF treated the crisis as involving fundamental issues of solvency, not liquidity. Moreover, it used the crisis to force these countries to adopt its own agenda for financial market reform. The IMF may have been right about the need for the banking reforms, but Radelet and Sachs are correct in suggesting that these should not have been initiated in the midst of a financial crisis. In retrospect, it does appear that the IMF program worsened the situation in Indonesia, and the initial program for Korea failed to deal with the overhang of maturing short-term foreign currency loans Some of the other reform measures, such as changes in labor market regulations, seem far removed from a currency crisis.

The authors are also critical of the IMF's restrictive targets for fiscal and monetary policy. Certainly, such measures would have never been adopted in the United States, and they do remind one of the mistaken response to the Depression of the early 1930s. At least with respect to monetary policy, though, the affected countries are caught in a difficult choice. On the one hand, higher interest rates are beneficial because they attract foreign currency; on the other hand, increased interest payments inflict an added burden on domestic enterprises. The emphasis on fiscal restraint is more difficult to rationalize. In effect, the IMF used a liquidity crisis to push an agenda of structural reform, whereas the first priority should have been to stop the panic. The IMF viewed the situation of these economies as no different from the traditional balance of payments crisis, in which a country is living beyond its means and is faced with the need to cut back domestic demand.

I believe that the authors could have done more to address the longer term issue of systemic reform. One big lesson for the other developing countries is that there is not going to be an international lender of last resort and they must develop a more defensive strategy of their own. I think that translates into a policy much closer to Chile's restrictions on short-term liabilities than the open market advice of the IMF and the United States. The industrialized countries have their own networks for 
providing financial support for each other, and they are not interested in providing additional resources to bail out developing countries.

I am troubled by the authors' emphasis on orderly workouts, because it appears inconsistent with the emphasis in the first part of the paper on liquidity as opposed to solvency. Nor do I understand the focus on bank lending. To some extent, the banks are simply the investors left behind when everyone else heads for the exits. Suppose that the Korean banks had issued commercial paper instead of borrowing from banks in Japan, Europe, and the United States. The debt would be equally difficult to roll over, but it would have been harder to identify who balked. All the current talk of forcing banks to take a larger hit is simply a means of discouraging future cross-border bank lending, which Chile accomplishes with an extra reserve requirement. However, Chile has concluded that the problem lies not in the instrument but in the maturity of the claim. Thus Chile limits short-term capital inflows, not just bank loans. There are also major questions about the appropriate degree of reliance on banks versus financial markets in a world of international capital flows. Previously, it was argued that banks provide more effective means of processing information about borrowers, but markets are more effective in spreading risks.

Holding larger reserves is not an attractive option, because it calls into question the value of open capital markets. What is the benefit of capital inflows if the government must set aside a substantial portion for U.S. Treasury bonds paying 3 percent? With investor expectations of returns of 10 percent or more, this does not look like a paying proposition. It is particularly sad in the case of these Asian economies, because they do not need the funds, given their own high rates of saving and capital formation.

Finally, the East Asian crises seem to provide further evidence that fixed exchange rates are no longer feasible. Governments should not promise something that they cannot deliver, and the effort to do so just breeds instability. Increasingly, the choice is between a single currency or flexible rates - the middle option is disappearing.

General discussion: Christopher Sims questioned the authors' distinction between liquidity problems and problems with fundamentals. $\mathrm{He}$ reasoned that a borrower who was fundamentally sound but had too many short-term debts to roll over should be able to borrow long to 
cover the short-term needs-he cited the historical example of Grover Cleveland's repeated issuance of long-term debt to defend the gold value of the dollar. That the Asian nations could not do so is a sign that their problems were fundamental. Robert Hall concurred and asked why, if the problem was merely one of liquidity, no private financier had stepped in to take advantage of the situation by arbitraging between long- and short-term debt. Sachs responded that the amounts needed for such an arbitrage operation were too big for a single private institution. The rapid downgrading of debt by international rating agencies also made it virtually impossible for lenders subject to fiduciary standards to intervene and buy the debt. In the case of Mexico, nobody had stepped in either. Michael Kremer suggested that if the IMF's purpose was to allow most of the arbitrage gains to accrue to the borrowing country, there would not be much room for the private sector to act ahead of the Fund.

Sims suggested that the correct definition of a fundamentals problem was the existence of a large number of contracts that could not be delivered on. That the countries in trouble resisted devaluation for so long because they feared the consequences for the net worth of borrowers, had to be regarded as a fundamental problem. Sims also commented on the lack of movement in interest rates before the crisis. He observed that lenders who were sensitive to borrower-specific risk would not offer to lend arbitrary amounts at a fixed rate, but rather would quote schedules of interest rates and quantities to borrowers. The absence of movements in interest rates does not prove that the crisis was completely unanticipated, as increased risk could also be reflected in a shortening of maturities. Furthermore, it was not appropriate to use the amount of short-term borrowing as an exogenous explanatory variable in regressions, since a shift in the maturity of debt before the crisis was itself endogenous.

James Duesenberry reasoned that fixed exchange rate regimes were at the heart of the trouble, because they invited the large capital inflows that proved destabilizing. The serious problems of bad domestic banking in Korea and Thailand added a vulnerability that created this specific crisis, and even if there had been no borrowing from abroad, they would eventually have created a domestic banking crisis. Looking ahead, this suggested it was important to slow down international capital movements, as well as to improve the banking systems and their supervision. 
Benjamin Friedman warned that even with better procedures for dealing with liquidity problems, including a lender of last resort, crises would occur unless borrowers and lenders had strong incentives to worry about risk management. To provide the proper incentives, it was important that creditors be allowed to lose money, as U.S. banks did in the 1980s.

William Cline argued that the paper's emphasis on a short-term crisis model downplayed a variety of fundamental problems that were apparent in the affected countries prior to the crisis. These included excessively rapid credit growth, overvalued fixed exchange rates, highly leveraged conglomerates, grandiose investment projects, low levels of foreign direct investment, and the poor incentives provided by the Bangkok interbank facility. He also defended the IMF against many of the authors' criticisms. He argued that its insistence on modest fiscal tightening and significantly higher interest rates in the Asian crisis sent a strong signal that these governments were seriously tackling the problems, providing benefits in confidence that could outweigh the direct contractionary effects of fiscal restraint. Furthermore, he believed that higher interest rates supported exchange rates, and that the burden for the economy from a lower exchange rate could be more severe than the burden from higher interest rates. In his view, the most convincing criticism of the IMF in this episode was the timing of the banking cleanup, particularly the closing of banks in Indonesia, which contributed to the bank runs there. He questioned whether major debt workouts would have been possible without the implementation of an IMF package.

Several participants commented on the problem posed by short-term capital movements. Cline believed there was a growing interest in limiting short-term capital buildups, but no consensus on whether this should be done by individual countries or through an international mandate. Maurice Obstfeld was skeptical about the authorities' ability to limit short-term money flows, because financial engineering could disguise short-term contracts as long-term contracts. Sachs thought these worries exaggerated, observing that all the countries in question had functioning capital controls until the early 1990s. Cooper noted that any attempt to limit flows would have to contend with the enormous growth of world interbank markets and the desire of emerging market banks to participate in it. He noted that when the Asian crisis hit, banks from that region called in loans to banks in other emerging markets, 
thus creating a risk that the crisis might spread. He added that portfolio equity investment has also proven to be highly liquid and mobile, even though it is conventionally counted as long-term capital. It adds volatility to stock prices and, if equities are used as collateral for borrowing, adds another source of credit risk. Michael Kremer suggested that a microeconomic externality that could justify government regulation of short-term borrowing arose from the fact that when one firm is called to pay its external debt, it drives down the currency, making it harder for other firms to fulfill their obligations. 


\section{References}

Amsden, Alice H. 1989. Asia's Next Giant: South Korea and Late Industrialization. Oxford University Press.

Asian Development Bank. 1997. Emerging Asia: Changes and Challenges. Manila.

Banerjee, Abhijit V. 1992. “A Simple Model of Herd Behavior." Quarterly Journal of Economics 107(3): 797-817.

Bank for International Settlements. 1997. "Annual Report." Basle.

. 1998. "The Maturity, Sectoral and Nationality Distribution of International Bank Lending." Basle (January).

Bosworth, Barry. 1998. "The Asian Crisis in Context: Some Generic Aspects of Currency Crises." Paper prepared for the Wharton-Long Term Credit Bank Conference. Tokyo, March 10.

Calvo, Guillermo A., and Enrique G. Mendoza. 1996. "Mexico's Balance of Payments Crisis: A Chronicle of a Death Foretold." Journal of International Economics 41(3-4): 235-64.

Cline, William R., and Kevin J. S. Barnes. 1997. "Spreads and Risk in Emerging Markets Lending." Research paper 97-1. Institute of International Finance (December).

Cole, David C., and Betty F. Slade. 1996. Building a Modern Financial System: The Indonesian Experience. Cambridge University Press.

Cooper, Richard N., and Jeffrey D. Sachs. 1985. "Borrowing Abroad: The Debtor's Perspective." In International Debt and the Developing Countries, edited by Gordon Smith and John T. Cuddington. Washington: World Bank.

Deininger, Klaus, and Lyn Squire. 1996. "Measuring Income Inequality: A New Data-Base." Development Discussion Paper 537. Cambridge, Mass.: Harvard Institute for International Development (May).

Diamond, Douglas W., and Philip H. Dybvig. 1983. "Bank Runs, Deposit Insurance, and Liquidity." Journal of Political Economy 91(3): 401-19.

Diaz-Alejandro, Carlos F. 1988. "Good-Bye Financial Repression, Hello Financial Crash." In Trade, Development and the World Economy: Selected Essays of Carlos F. Diaz-Alejandro, edited by Andrés Velasco. Oxford: Basil Blackwell.

Dooley, Michael P. 1997. “A Model of Crises in Emerging Markets.” Working Paper 6300. Cambridge, Mass.: National Bureau of Economic Research (December).

Dornbusch, Rudiger, Ilan Goldfajn, and Rodrigo O. Valdés. 1995. "Currency Crises and Collapses." BPEA, 2:1995, 219-93.

Edwards, Sebastian. 1996. "A Tale of Two Crises: Chile and Mexico." Working paper 5794. Cambridge, Mass.: National Bureau of Economic Research (October). 
1998. "The Mexican Peso Crisis: How Much Did We Know? When Did We Know It?" World Economy 21(1): 1-30.

Eichengreen, Barry, Andrew K. Rose, and Charles Wyplosz. 1995. "Exchange Market Mayhem: The Antecedents and Aftermath of Speculative Attacks." Economic Policy 21: 249-312.

Feldstein, Martin. 1998. "Refocusing the IMF."'Foreign Affairs 77(2): 2033.

Friedman, Milton, and Anna Jacobson Schwartz. 1963. A Monetary History of the United States, 1867-1960. Princeton University Press.

Hill, Hal. 1996. ' Indonesia's Industrial Policy and Performance: 'Orthodoxy' Vindicated." Economic Development and Cultural Change 45(1): 147-74.

International Monetary Fund. 1997a. "Indonesia-Request for a Stand-By Arrangement." Washington (October 31).

(December 3).

- 1997c. "Philippines-Recent Economic Developments." Staff Country Report 97/28. Washington (April).

. 1997d. "Thailand-Memorandum on Economic Policies." Washington (August 14).

- 1998a. "Communique of the Interim Committee of the Board of Governors of the International Monetary Fund.' Washington (April 16).

- 1998b. "Indonesia-Memorandum of Economic and Financial Policies." Washington (January 15).

. 1998c. World Economic Outlook. Washington.

Kaminsky, Graciela L., and Carmen M. Reinhart. 1996. "The Twin Crises: The Causes of Banking and Balance-of-Payments Problems." International Finance Discussion Paper 544. Washington: Board of the Governors of the Federal Reserve System (March).

Kindleberger, Charles P. 1996. Manias, Panics, and Crashes: A History of Financial Crises, 3d. ed. John Wiley.

Krugman, Paul. 1998. "What Happened to Asia?' Unpublished paper. Massachusetts Institute of Technology (January).

McKinnon, Ronald I., and Huw Pill. 1996. "Credible Liberalizations and International Capital Flows: The 'Overborrowing Syndrome.',' In Financial Deregulation and Integration in East Asia, edited by Takatoshi Ito and Anne O. Krueger. University of Chicago Press.

Mishkin, Frederic S. 1991. "Asymmetric Information and Financial Crises: A Historical Perspective." In Financial Markets and Financial Crises, edited by R. Glenn Hubbard. University of Chicago Press.

Nehru, Jawaharlal. 1946. The Discovery of India. New York: John Day.

Park, Yung Chul. 1996. "East Asian Liberalization, Bubbles, and the Challenge from China." BPEA, 2:1996, 357-71. 
. 1998. "Financial Crisis and Macroeconomic Adjustments in Korea, 1997-98." ' Unpublished paper. Korea Institute of Finance (March).

Perkins, Dwight H. 1994. "There Are at Least Three Models of East Asian Development." World Development 22(4): 655-61.

Political Risk Services. Various years. International Country Risk Guide. Syracuse, N.Y.

Radelet, Steven, and Jeffrey D. Sachs. 1997. “Asia's Reemergence." Foreign Affairs 76(6): 44-59.

- 1998. "The Onset of the East Asian Currency Crisis." Unpublished paper. Harvard Institute for International Development.

Radelet, Steven, Jeffrey D. Sachs, and Jong-Wha Lee. 1997. "Economic Growth in Asia." Development Discussion Paper 609. Cambridge, Mass.: Harvard Institute for International Development (November).

Sachs, Jeffrey D. 1984. "Theoretical Issues in International Borrowing." Princeton Studies in International Finance 54.

. 1995. "Do We Need an International Lender of Last Resort?" Presented as the Frank D. Graham Lecture. Princeton University, April 20.

Sachs, Jeffrey D., Aaron Tornell, and Andrés Velasco. 1996a. "The Collapse of the Mexican Peso: What Have We Learned?' Economic Policy 22: 1356.

- 1996b. "Financial Crises in Emerging Markets: The Lessons from 1995." BPEA, 1:1996, 147-215.

$\rightarrow$ Stiglitz, Joseph E., and Andrew Weiss. 1981. "Credit Rationing in Markets with Impefect Information." Amercian Economic Review 71(3): 393-410.

Wade, Robert. 1990. Governing the Market: Economic Theory and the Role of Government in East Asian Industrialization. Princeton University Press.

Wigmore, Barrie A. 1987. "Was the Bank Holiday of 1933 Caused by a Run on the Dollar?" Journal of Economic History 47(3): 739-55.

World Bank. 1997. "Indonesia: Sustaining High Growth with Equity." Report 16433-IND. Country Department 3, East Asia and Pacific Region. Washington (May). 